UNIVERSIDADE DE SÃO PAULO

ESCOLA DE ENGENHARIA DE SÃO CARLOS

DEPARTAMENTO DE GEOTECNIA

ELAINE NOGOSEKE

COMPARTIMENTAÇÃO DE MACIÇOS ROCHOSOS PARA

PROJETOS BÁSICOS DE PCH'S USANDO O SISTEMA RMR

APLICAÇÃO NO PROJETO BÁSICO DA PCH MORRO GRANDE - RS

São Carlos 

ELAINE NOGOSEKE

\section{COMPARTIMENTAÇÃO DE MACIÇOS ROCHOSOS PARA \\ PROJETOS BÁSICOS DE PCH'S USANDO O SISTEMA RMR \\ APLICAÇÃO NO PROJETO BÁSICO DA PCH MORRO GRANDE - RS}

Dissertação apresentada à Escola de Engenharia de São Carlos da Universidade de São Paulo para obtenção do título de Mestre em Geotecnia

Orientador: Prof. Dr. Oswaldo Augusto Filho

São Carlos 



\section{AGRADECIMENTOS}

Ao Conselho Nacional de Desenvolvimento Científico e Tecnológico - CNPq, pelo incentivo acadêmico oferecido.

Ao Prof. Dr. Oswaldo Augusto Filho, pela orientação, discussões e sugestões que colaboraram para o desenvolvimento deste estudo.

Ao departamento de Geotecnia, que permitiu a realização deste trabalho, aos professores pelos conhecimentos transmitidos, e aos funcionários Maristela, Álvaro e Neiva, sempre muito atenciosos.

À Design Head Engenharia e Construtora pelo fornecimento de dados sobre a PCH Morro Grande, em especial aos amigos Alberto e Bete pelo apoio e compreensão neste período, ao Alvaro pelos esclarecimentos em questões técnicas, e ao Anderson por todo o auxílio dado em campo.

Aos amigos feitos em são Carlos, Juliana, Dani, Daninha, Kelly, Wagner, Sérgio, Rafaela, Juan, Felipe, Junio, Simone, Valéria, Vanessa, Luciene e Crisley, e em especial à Aline, pela amizade e carinho.

Aos meus pais, por todo incentivo e carinho que me deram em todos os momentos da minha vida. À Angela e à Debora, minhas grandes amigas, que acompanharam os primeiros passos dessa jornada, aos amigos Gustavo, Edgar, Elis e Felipe.

Em especial ao Leonardo, que me acompanhou nesse período, pelo incentivo, amizade e amor dedicados. 

RESUMO

Com a abertura do setor de geração de energia elétrica no país houve um aumento do número de projetos para Pequenas Centrais Hidrelétricas - PCHs. Os estudos geológicogeotécnicos necessários para este tipo de obra tiveram que se adaptar às necessidades deste novo setor, sem haver perda da qualidade. O objetivo deste trabalho foi o aprimoramento dos estudos de compartimentação geológico-geotécnicos, utilizando um dos sistemas de classificação de maciços rochosos mais conhecidos: o Sistema RMR - rock mass rating - (Bieniawski, 1973), analisando as vantagens, as desvantagens, e o potencial de aplicação do método. A pesquisa foi aplicada na PCH Morro Grande, localizada no Rio Grande do Sul, que apresenta uma grande homogeneidade geológica, sendo o embasamento constituído por derrames basálticos da Formação Serra Geral. Foram propostas algumas modificações na forma de aplicação do sistema RMR, como não précompartimentar o maciço, aplicar a classificação diretamente nos testemunhos de sondagem e de forma parcial nos afloramentos, e substituir o RQD (rock quality designation) pelo IQR (índice de qualidade da rocha). Para caracterizar a resistência da rocha foram feitos ensaios de compressão puntual, associados aos diferentes graus de alteração da rocha. O resultado foi apresentado em seções do eixo da barragem e do circuito hidráulico. A metodologia proposta resultou na compartimentação detalhada do maciço rochoso, na área das estruturas da $\mathrm{PCH}$, mostrando-se uma ferramenta útil para a determinação da compartimentação de maciços rochosos, principalmente de maciços homogêneos, podendo ser aplicada de forma rápida e a um custo baixo para o projeto. 
ABSTRACT

The opening of the electric production sector in Brazil causes an increase amount of Small Hydroelectric Power Station - PCH's - project. The necessaries geological-geotechnical studies for this kind of construction had to be adapted to this new sector necessity, without quality losses. This research aim was the improvement of the geological-geotechnical studies, using one of the most well-known rock mass classification systems: the RMR system - rock mass rating - (Bieniawski, 1973), and analyze the advantage, the disadvantage, and potential of this method application. This research was applied to Morro Grande $\mathrm{PCH}$, located on Rio Grande do Sul State - Brazil, which has great geologic homogeneity, and its rock foundation is basaltic rocks of the Serra Geral Formation. Some modification in the RMR application way has been proposal, like don't pre-divide the rock mass, apply the system directly in the core logging and partially to the outcrops, and change RQD (rock quality designation) by IQR (rock quality index). To rock strength have been established by point-load test, for the different weathering degrees of the rock samples. The results are presented on profiles of the structures axis. The propose method resulted in detailed compartmentalization of the structures areas, turning into an useful tool to assist the rock mass analyses, mainly to homogeneous rock masses, been applied quickly and at low costs. 


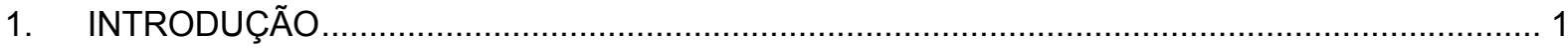

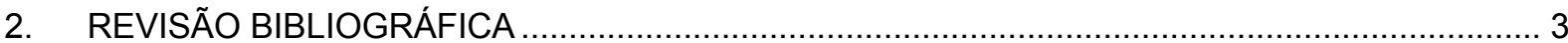

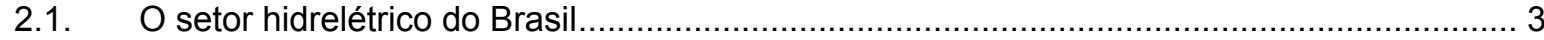

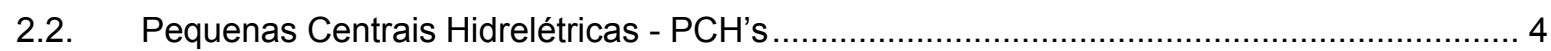

2.3. Caracterização geológico-geotécnica de maciços rochosos............................................. 5

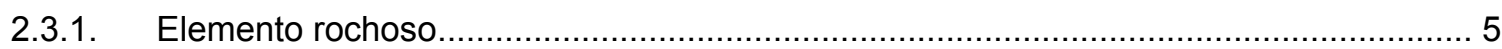

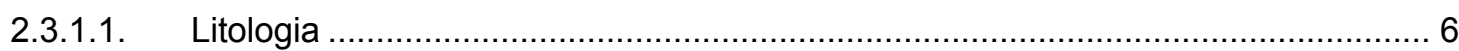

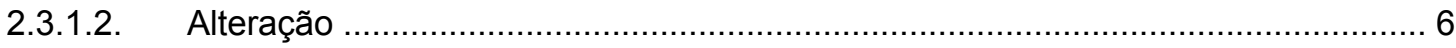

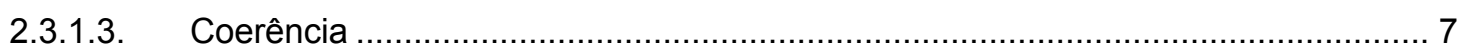

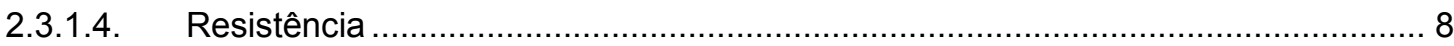

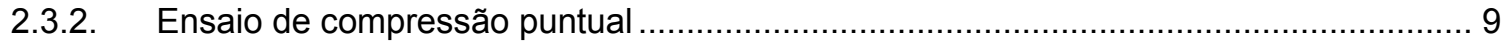

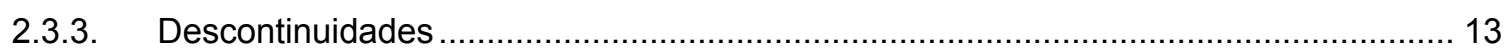

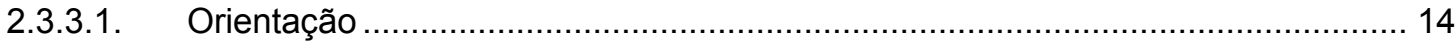

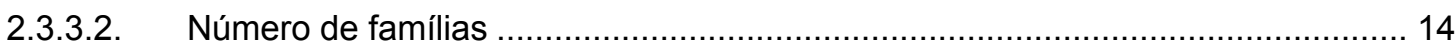

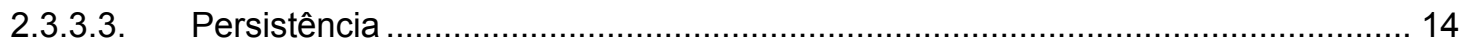

2.3.3.4. Alteração das paredes das descontinuidades .................................................. 15

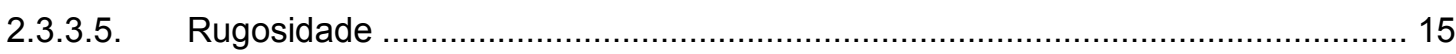

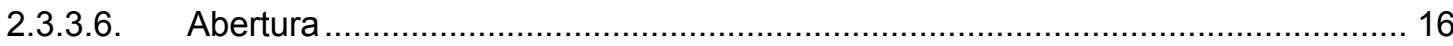

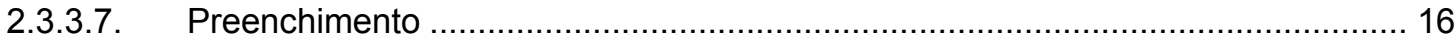

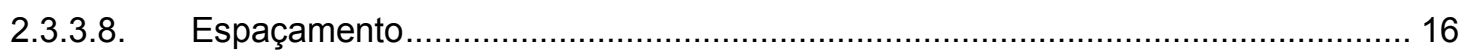

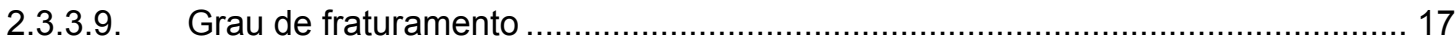

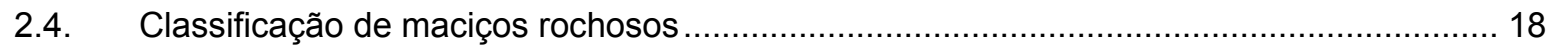

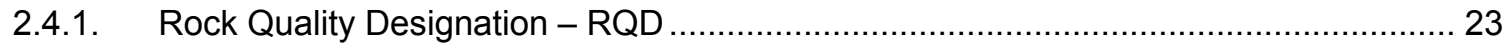

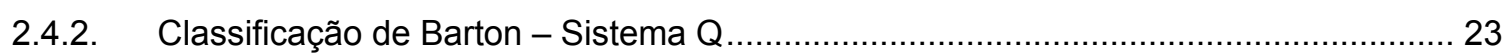

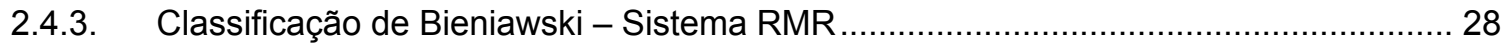

2.4.4. Classificações brasileiras utilizadas em barragens .................................................. 32

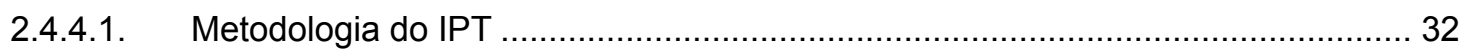

2.4.4.2. Classificação geotécnica preliminar de Guidicini ................................................ 33

2.4.4.3. Modelo de compartimentação de Monticeli....................................................... 33

2.4.5. Casos de aplicação de sistemas de classificação em barragens ................................. 35 


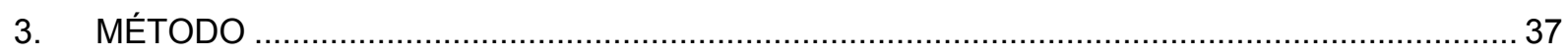

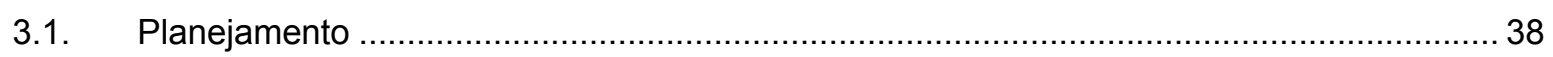

3.1.1. Definição da metodologia e seleção do sistema de classificação................................... 38

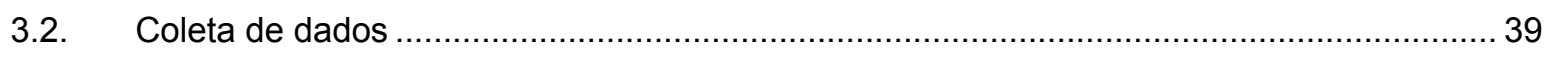

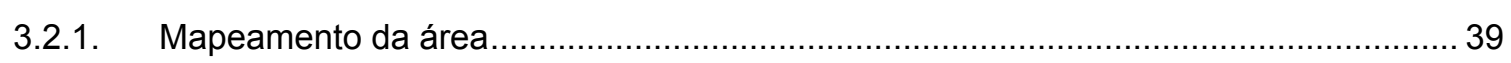

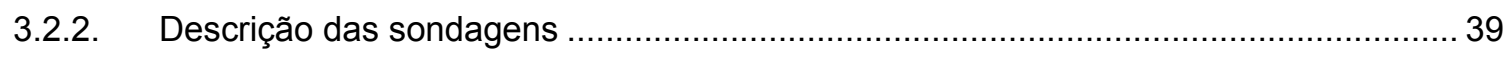

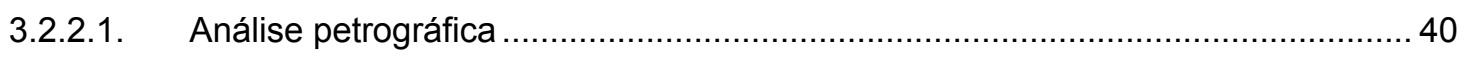

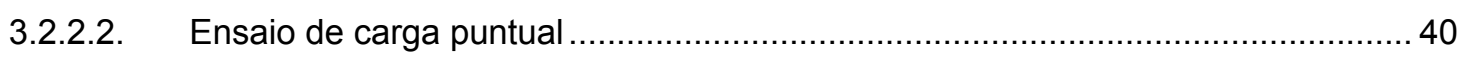

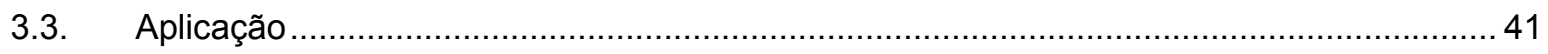

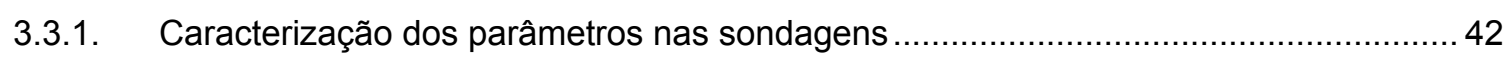

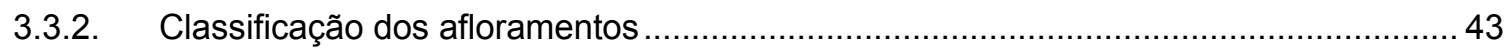

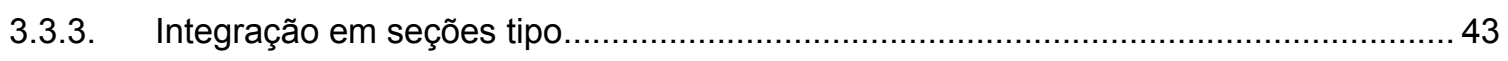

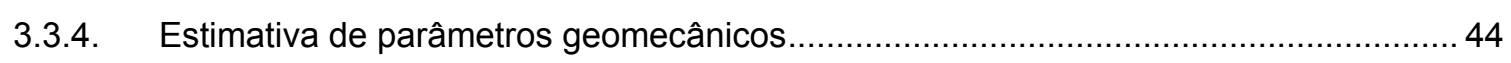

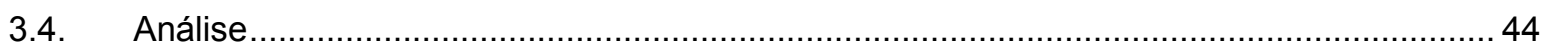

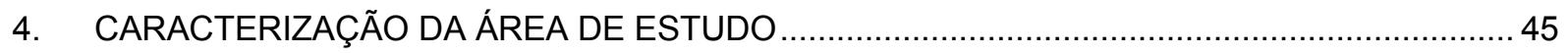

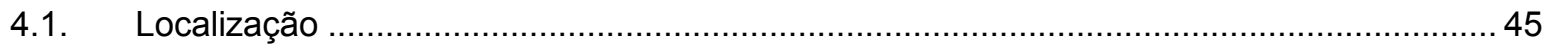

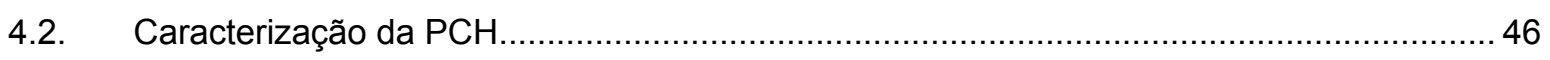

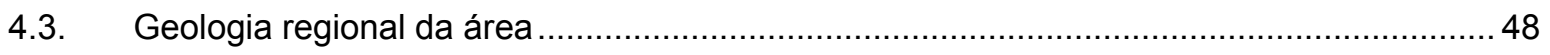

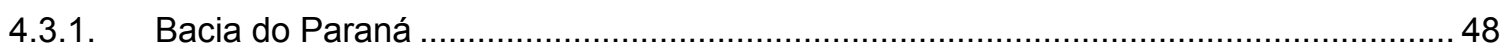

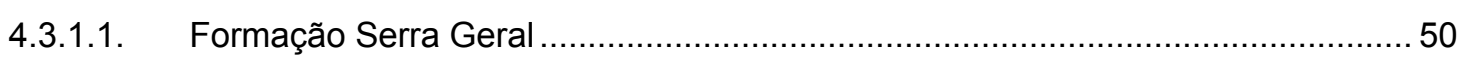

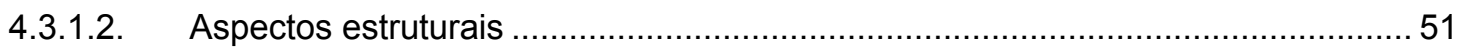

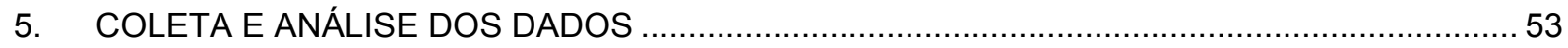

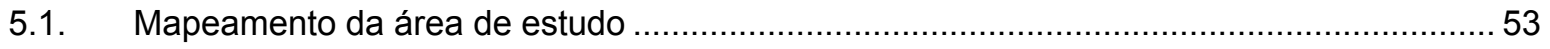

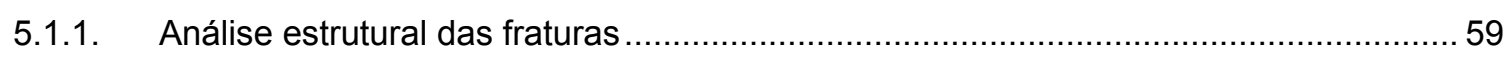

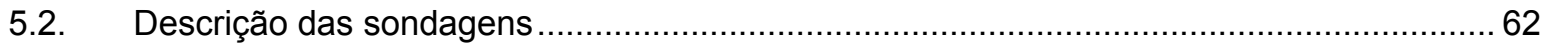

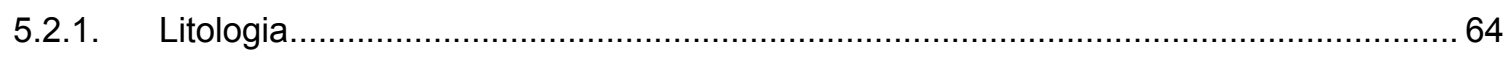

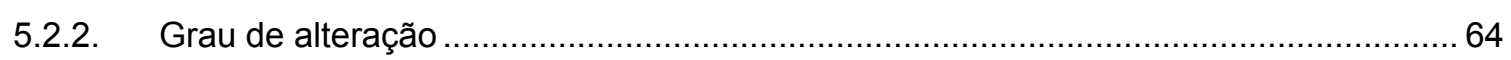

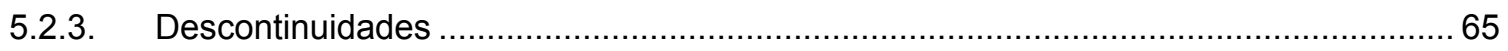

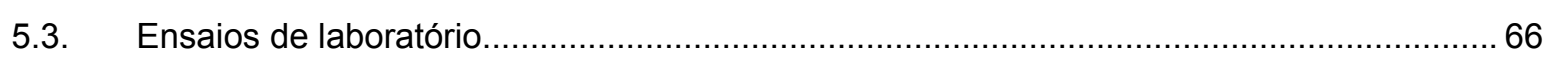

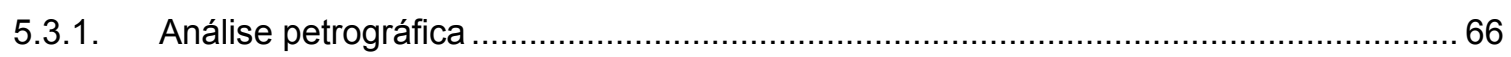

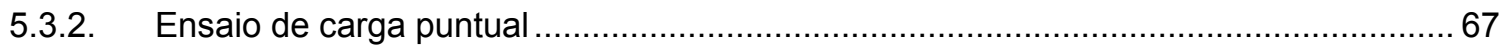

6. APLICAÇÃO DO SISTEMA RMR

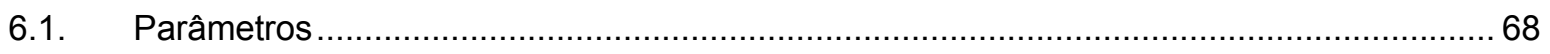

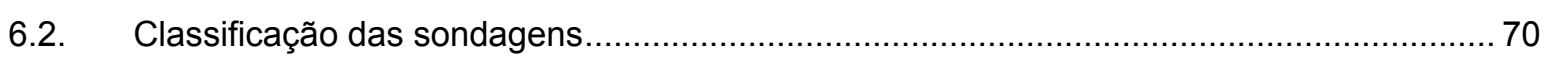

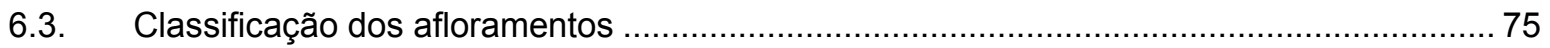


7. INTEGRAÇÃO DOS RESULTADOS EM SEÇÕES TIPO.

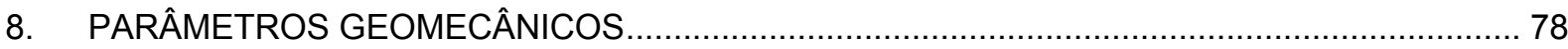

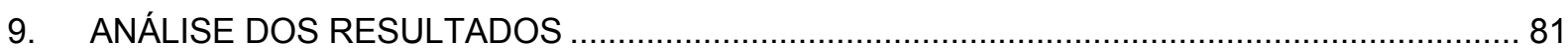

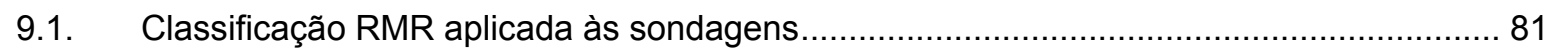

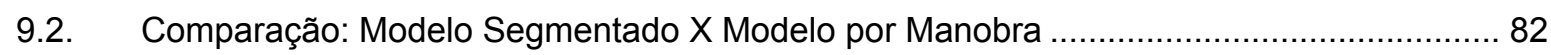

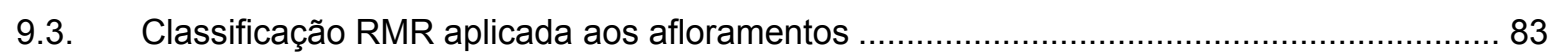

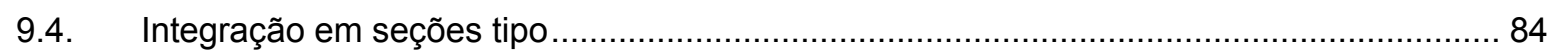

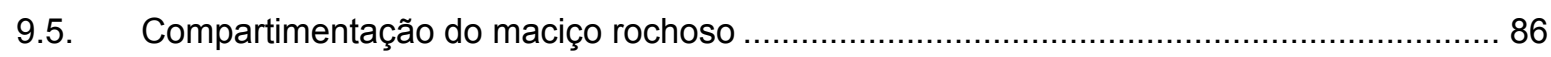

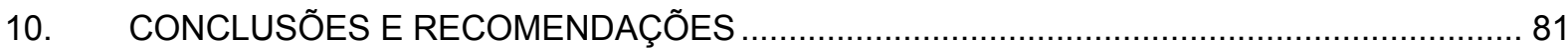

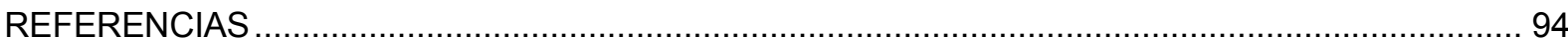

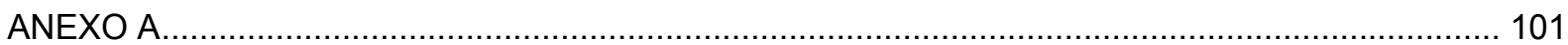

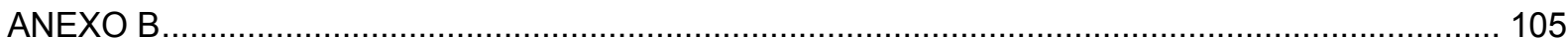

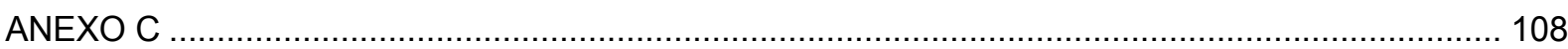




\section{LISTA DE FIGURAS}

Figura 1 - Forma da amostra e tipo de ensaio de compressão puntual indicado. (ISRM, 1985) ......... 10

Figura 2 - Gráfico do fator de correção do tamanho. (ISRM, 1985) ................................................... 12

Figura 3 - Perfis de rugosidade (Barton et al. 1974 apud Serra Junior e Ojima, 1998)..................... 15

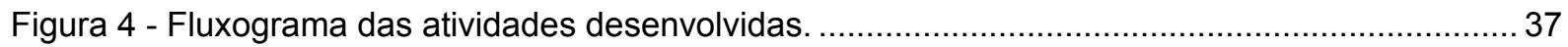

Figura 5 - Equipamento de compressão puntual, e posicionamento da amostra para o ensaio. ........ 41

Figura 6 - Aferição das dimensões da amostra, largura e diâmetro. ................................................... 41

Figura 7 - Figura esquemática coma a localização da área de estudo.............................................. 45

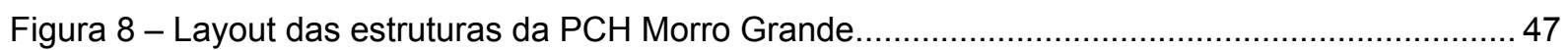

Figura 9 - Mapa geológico simplificado da Bacia do Paraná (modificado de Milani, 1998)................. 49

Figura 10 - Arcabouço Estrutural da Bacia do Paraná. (modificado Zalán et al. 1987) ....................... 52

Figura 11 - Afloramento do ponto 01 , detalhe para o fraturamento sub-horizontal. ........................... 53

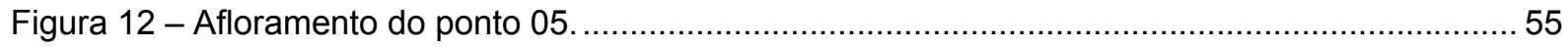

Figura 13 - Afloramento do ponto 12, detalhe para o forte fraturamento sub-horizontal, e para

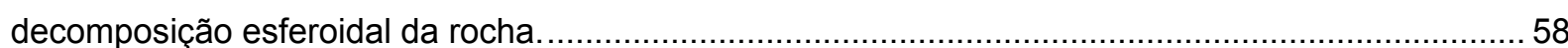

Figura 14 - Diagramas de rosetas das fraturas. $(\mathrm{N}=$ número de medidas) ........................................ 60

Figura 15 - Mapa de pontos de campo com diagrama de roseta das fraturas sobreposto ao esboço geológico da área.

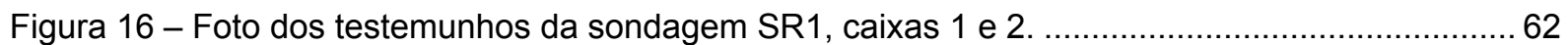

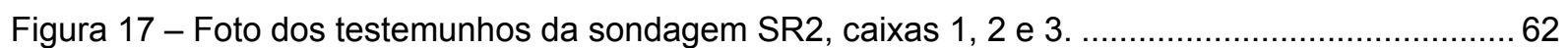

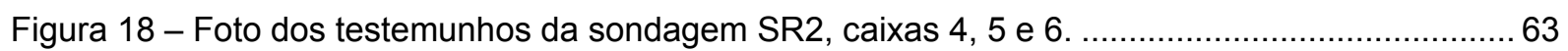

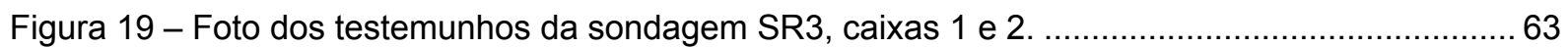

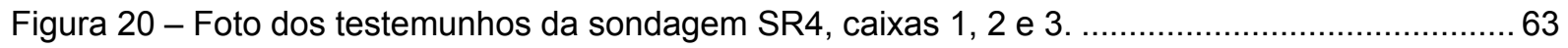

Figura 21 - Amostra de dacito com fratura aberta preenchida por veio de zeólita. ............................ 64

Figura 22 - Amostras de rocha no diferentes graus de alteração encontrados. .................................. 65

Figura 23 - Exemplos de rugosidade encontrados nas fraturas das sondagens. ............................... 66

Figura 24 - Boletim de descrição da sondagem SR1, com a classificação RMR. ……...................... 71

Figura 25 - Boletim de descrição da sondagem SR2, com a classificação RMR. …........................... 72

Figura 26 - Boletim de descrição da sondagem SR3, com a classificação RMR. ……………............ 73

Figura 27 - Boletim de descrição da sondagem SR4, com a classificação RMR. …………………... 74

Figura 28 - Seção da barragem com compartimentação pelo sistema RMR ....................................... 79

Figura 29 - Seção do circuito hidráulico com compartimentação pelo sistema RMR. ........................ 80 


\section{LISTA DE TABELAS}

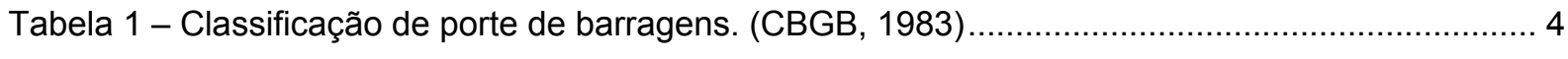

Tabela 2 - Graus de alteração de rocha (IPT, 1984, apud Serra Junior e Ojima, 1998) ..................... 6

Tabela 3 - Graus de coerência (Guidicini et al, 1972a) ........................................................................ 8

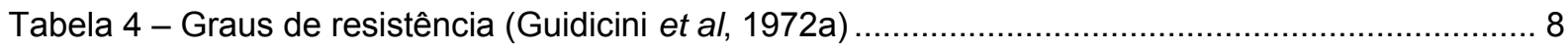

Tabela 5 - Classificação de persistência (ISRM, 1978) …......................................................... 15

Tabela 6 - Classificação de aberturas de descontinuidades (ISRM, 1978) ....................................... 16

Tabela 7 - Classificação de espaçamento (ISRM, 1978) ........................................................... 17

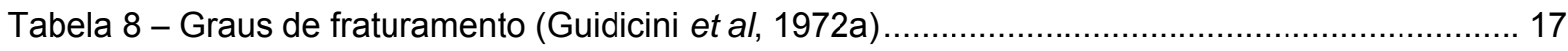

Tabela 9 - Valores de RQD - Classificação geomecânica de BARTON et al, (1974)......................... 25

Tabela 10 - Valores de Jn - Classificação geomecânica de BARTON et al, (1974)......................... 25

Tabela 11 - Valores de Jr - Classificação geomecânica de BARTON et al, (1974)............................ 25

Tabela 12 - Valores de Ja - Classificação geomecânica de BARTON et al, (1974) ............................ 26

Tabela 13 - Valores de Jw - Classificação geomecânica de BARTON et al, (1974). ......................... 26

Tabela 14 - Valores de SRF - Classificação geomecânica de BARTON et al, (1974)........................ 27

Tabela 15 - Classes de maciços rochosos - Sistema Q (BARTON et al, 1974) . ............................... 28

Tabela 16 - Classificação geomecânica de Bieniawski (1989) ....................................................... 29

Tabela 17 - Efeito da direção geológica e do mergulho na construção de túneis ............................... 30

Tabela 18 - Efeito da direção geológica em fundações de barragens (Bieniawski e Orr, 1976)......... 30

Tabela 19 - Orientação para a classificação das condições das descontinuidades............................ 30

Tabela 20 - Classes do maciço determinada pela soma total dos pesos.......................................... 30

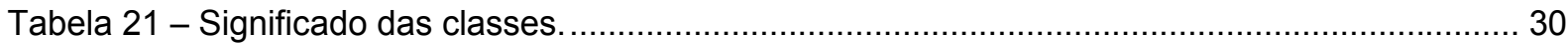

Tabela 22 - Planilha de aplicação do sistema RMR na sondagem SR1 ....................................... 70

Tabela 23 - Planilha de atribuição dos pesos relativos aos afloramentos de campo. ......................... 75

Tabela 24 - Parâmetros geomecânicos calculados a partir da nota RMR ………….......................... 78 
LISTA DE SIGLAS E ABREVIATURAS

ABGE Associação Brasileira de Geologia de Engenharia e Ambiental

AHE Aproveitamento Hidrelétrico

ANEEL Agência Nacional de Energia Elétrica

CBGB Comitê Brasileiro de Barragens

CHESF Companhia Hidro Elétrica do São Francisco

DNAEE Departamento Nacional de Águas e Energia Elétrica

EESC Escola de Engenharia de São Carlos

IPT Instituto de Pesquisas Tecnológicas do Estado de São Paulo

IQR Índice de Qualidade da Rocha

ISRM International Society for Rock Mechanics

NATM New Austrian Tunnelling Method

$\mathrm{PCH} \quad$ Pequena Central Hidrelétrica

RMR Rock Mass Rating

RQD Rock Quality Designation

RSR Rock Structure Rating

UFPR Universidade Federal do Paraná

UHE Usina Hidrelétrica

UTM Sistema Universal Transverso de Mercartor 


\section{INTRODUÇÃO}

A partir da década de 90 houve um crescente aumento nos estudos de projetos de PCH's causado pela abertura do setor de geração de energia elétrica para a iniciativa privada. As PCH's aparecem com a vantagem de aproveitar potenciais hídricos em locais onde não se poderia construir uma grande obra e pulverizando empreendimentos em diversos municípios, causando menos impactos ao meio ambiente. As áreas diretamente afetadas normalmente compreendem poucos hectares, e os reservatórios, em sua maioria, se caracterizam apenas por um aumento de poucos metros no nível do rio, atingindo poucos proprietários.

Apesar de poder ser considerada uma obra muito menor em relação às hidrelétricas de grande porte, as PCH's são obras de engenharia com grandes riscos sociais e econômicos envolvidos, demandando todos os cuidados em relação aos condicionantes geológicogeotécnicos na elaboração de seus projetos. A realização de um número menor de investigações e ensaios é comumente justificada por condições de contorno de projeto menos críticas, como o nível mais baixo de tensões no maciço e reservatórios de menor porte.

Os estudos geotécnicos necessários para esse tipo de obra já são bem conhecidos, e tiveram um grande avanço nas décadas de setenta e oitenta, quando se construíram as principais usinas hidrelétricas do país. Entretanto, na sua maioria, são métodos voltados às grandes barragens, necessitando de recursos significativos, muitas vezes não aplicáveis aos projetos de PCH's. Este cenário indica que é necessário achar o equilíbrio entre os métodos de investigação tradicionais, os recursos disponíveis para o estudo do maciço, e o grau de conhecimento necessário para a implantação da obra. Nesse sentido o estudo de compartimentação do maciço rochoso aparece como uma alternativa para melhorar o 
conhecimento geológico-geotécnico da área, permitindo já nas fases iniciais de projeto, a elaboração de modelos geotécnicos e geomecânicos.

O objetivo deste trabalho foi o aprimoramento dos estudos de compartimentação geológicogeotécnicos atualmente utilizados nos projetos de $\mathrm{PCH}$ 's, tendo como referência geral o sistema de classificação de maciços rochosos RMR. O estudo foi aplicado na área da PCH Morro Grande (RS), com a avaliação dos ganhos obtidos no entendimento geotécnico deste local em relação a abordagem tradicional.

Para tanto foram feitas adequações na forma de aplicação deste sistema de classificação, sem a pré-divisão do maciço em zonas homogêneas, e utilizando o sistema RMR como ferramenta para determinar a compartimentação do maciço rochoso. 


\section{REVISÃO BIBLIOGRÁFICA}

\subsection{O setor hidrelétrico do Brasil}

Segundo Paulon e Martins Neto (2000) a primeira experiência com energia elétrica no Brasil ocorreu no ano de 1883 em Diamantina, Minas Gerais, com a extração de diamantes. Foram a mineração, as indústrias e a iluminação pública que impulsionaram a criação das primeiras usinas. A maioria destas unidades era de pequena potência, implantadas diretamente abaixo das quedas d'água. A partir de 1920 passam a ser construídas usinas de maior porte, capazes de atender à constante ampliação do mercado, constituído principalmente pela iluminação pública e a difusão dos bondes elétricos, além das indústrias. Até o final dos anos 40 os principais empreendimentos hidrelétricos tinham sido incorporados a duas companhias estrangeiras - a Light, canadense, e a Amforp, americana - que detinham o monopólio do setor no país. Em 1945 foi criada a primeira empresa de eletricidade do governo federal, a Companhia Hidrelétrica do São Francisco - CHESF, que marca a intervenção do estado na geração da energia elétrica. A partir de 1950 o modelo energético no país muda, sendo criadas as grandes empresas estaduais e federais, com a tendência à construção de usinas de grande porte, e dissociando a geração de energia da distribuição.

Cruz (1996) relata a evolução do ciclo das barragens brasileiras, destacando nas décadas de 50 e 60 a informalidade e a falta de conhecimento técnico. O acúmulo do conhecimento gerado neste período faz com que nos anos seguintes ocorra uma crescente formalização dos projetos, sendo desenvolvidos os laboratórios de pesquisas, e passando a ocorrer concorrências públicas para as fases construtivas. Os projetos, que antes se encontravam concentrados na região centro-sul, passam a ser desenvolvidos também no norte e na região amazônica. Entre as décadas de 80 e 90 surge a preocupação com o meio ambiente, e os estudos de impacto ambiental passam a ser obrigatórios. Segundo o autor, a partir 
deste período terminam-se os projetos em andamento e não se iniciam novas obras. Mais de uma década depois da publicação do trabalho de Cruz (1996), o setor hidrelétrico se vê novamente voltado aos projetos de obras de pequeno porte. Em 1995 ocorre a reestruturação do setor elétrico brasileiro, terminando o monopólio estatal da geração de energia. Em 1996 é criada a Agência Nacional de Energia Elétrica - ANEEL, que tem o papel de regular e fiscalizar o setor, assumindo as atividades do extinto Departamento Nacional de Águas e Energia Elétrica - DNAEE.

\subsection{Pequenas Centrais Hidrelétricas - PCH's}

PCH's são pequenas usinas hidrelétricas, cujo objetivo é a geração de energia elétrica. $\mathrm{O}$ termo PCH foi definido pela ANEEL através da Resolução 395 de 04 de dezembro de 1998, como sendo os aproveitamentos hidrelétricos de potência superior a $1.000 \mathrm{~kW}$ e igual ou inferior a $30.000 \mathrm{~kW}$, e com área inundada de até $3 \mathrm{Km}^{2}$ para a cheia centenária, não havendo demais restrições quanto ao tipo, arranjo, ou dimensão das estruturas utilizadas.

As PCH's podem apresentar estruturas de grande porte, principalmente com relação à barragem. Segundo o Comitê Brasileiro de Barragens - CBGB (1983) as barragens podem ser de pequeno, médio e grande porte conforme a Tabela 1, dependendo da altura e do volume de água armazenada no reservatório.

Tabela 1 - Classificação de porte de barragens. (CBGB, 1983)

\begin{tabular}{|c|c|c|}
\hline Categoria & Altura $(\mathbf{m})$ & Armazenamento (m3) \\
\hline Pequena & 5 a 10 & $0,05 \times 10^{6}$ a $1,0 \times 10^{6}$ \\
\hline Média & 15 a 30 & $1,0 \times 10^{6}$ a $50,0 \times 10^{6}$ \\
\hline Grande & Maior que 30 & Maior que $50,0 \times 10^{6}$ \\
\hline
\end{tabular}


As barragens podem também ser classificadas quanto ao potencial de risco que oferecem para as pessoas e benfeitorias (Gehring, 1987), em função de fatores como: tipo de barragem, volume do reservatório, altura da barragem, distância da barragem ao primeiro aglomerado urbano ou propriedade à jusante, diferença de cotas entre a superfície do reservatório e o núcleo urbano, densidade populacional à jusante e sismicidade de região.

Os componentes básicos de uma $\mathrm{PCH}$ são: barragem, tomada d'água, canal e/ou túnel adutor, câmara de carga, conduto forçado, casa de força e canal de fuga, sendo que a presença dessas estruturas depende do tipo de arranjo da $\mathrm{PCH}$.

\subsection{Caracterização geológico-geotécnica de maciços rochosos}

Um maciço rochoso é constituído por um conjunto de blocos de rocha justapostos, separados por descontinuidades, e é a relação entre a quantidade de descontinuidades e a escala da obra que indica o grau de isotropia do meio (Serra Júnior e Ojima, 1998). Contudo, o comportamento do maciço não se restringe apenas a quantidade de descontinuidades, mas é influenciado pelas condições que essas descontinuidades apresentam. Portanto, algumas considerações sobre elementos geológicos envolvidos tornam-se necessárias.

\subsubsection{Elemento rochoso}

A porção rochosa apresenta características que exercem uma parcela de influência no comportamento do maciço como um todo. Isso faz com que uma descrição correta e padronizada dessas características seja necessária para um bom resultado. 


\subsubsection{Litologia}

Segundo Serra Junior e Ojima (op.cit) a classificação litológica para aplicação em engenharia deve apoiar-se em conceitos petrográficos de uso corrente da geologia, mas deve ser simplificada e objetiva, adotando como critérios o grupo genético, as estruturas principais, textura, granulação e mineralogia. Um maior detalhamento litológico pode ser realizado conforme haja necessidade no decorrer dos estudos.

\subsubsection{Alteração}

Alteração é o conjunto de modificações físico-químicas a que as rochas se encontram submetidas, e que conduz à degradação de suas características mecânicas (Serra Junior e Ojima, 1998). A caracterização do estado de alteração é feita tátil-visualmente, com base em variações do brilho e da cor dos minerais da rocha, além da friabilidade. A

Tabela 2 apresenta uma classificação básica de graus de alteração de rochas.

Guidicini et al (1972a) consideram o grau de alteração o parâmetro mais difícil de ser definido em campo, e limitam a três os graus de alteração, devido ao fato de que como a determinação de limites é muito subjetiva, o emprego de um maior número de graus seria pouco prática. Os graus propostos são rocha sã (A1); alterada (A2); e muito alterada (A3).

Tabela 2 - Graus de alteração de rocha (IPT, 1984, apud Serra Junior e Ojima, 1998)

\begin{tabular}{|c|c|c|}
\hline Siglas & Denominação & Características da rocha \\
\hline $\begin{array}{l}\text { A1 } \\
\text { W1 } \\
\text { RS }\end{array}$ & $\begin{array}{l}\text { Sã ou } \\
\text { praticamente sã }\end{array}$ & $\begin{array}{l}\text { Apresenta minerais primários sem vestígios de alterações ou com } \\
\text { alterações físicas e químicas insipientes. Neste caso a rocha é } \\
\text { ligeiramente descolorida. }\end{array}$ \\
\hline $\begin{array}{c}\text { A2 } \\
\text { W2 } \\
\text { RAD }\end{array}$ & $\begin{array}{l}\text { Moderadamente } \\
\quad \text { alterada }\end{array}$ & $\begin{array}{l}\text { Apresenta minerais moderadamente alterados e a rocha é bastante } \\
\text { descolorida. }\end{array}$ \\
\hline $\begin{array}{c}\text { A3 } \\
\text { W3 } \\
\text { RAM }\end{array}$ & Muito alterada & $\begin{array}{c}\text { Apresenta minerais muito alterados, por vezes pulverulentos e } \\
\text { friáveis. }\end{array}$ \\
\hline $\begin{array}{c}\text { A4 } \\
\text { W4 } \\
\text { REA }\end{array}$ & $\begin{array}{l}\text { Extremamente } \\
\quad \text { alterada }\end{array}$ & $\begin{array}{l}\text { Apresenta minerais totalmente alterados e a rocha é intensamente } \\
\text { descolorida, gradando para cores de solo. }\end{array}$ \\
\hline
\end{tabular}


Segundo Vaz (1996) a utilização de critérios baseados na alteração mineralógica e na porcentagem relativa de solos e blocos, utilizados para a definição de horizontes de alteração, é subjetiva e dificilmente reproduzíveis por observadores diferentes em um mesmo perfil.

Para o Instituto de Pesquisas Tecnológicas do Estado de São Paulo - IPT (1983) a caracterização do estado de alteração das rochas é normalmente abordada através de critérios qualitativos, onde a avaliação é visual, ou quantitativos, onde são utilizados diversos ensaios para avaliação das características mecânicas das rochas, tais como: deformabilidade e ruptura; velocidade de propagação de ondas elásticas; porosidade e permeabilidade; expansibilidade; e desgaste em meio úmido. Os critérios de alteração qualitativos se aplicam bem às rochas duras, mas em rochas sedimentares estas observações podem não apresentar um resultado satisfatório, sendo necessária a utilização de métodos quantitativos, ou a utilização de parâmetros de coerência.

\subsubsection{Coerência}

A coerência baseia-se em propriedades como tenacidade, dureza e friabilidade das rochas, e também é determinada tátil-visualmente com a observação da resistência que a rocha oferece ao impacto do martelo e ao risco com lâmina de aço (Guidicini et al, 1972a). A Tabela 3 apresenta os critérios para definição da coerência das rochas.

Segundo Serra Junior e Ojima (1998), os parâmetros de alteração e coerência permitem perceber a ação intempérica sobre o maciço rochoso, e conseqüentemente as possíveis alterações nas características mecânicas das rochas, especialmente sobre a resistência, que sofre significativa redução nos estágios inicias de alteração. 
Tabela 3 - Graus de coerência (Guidicini et al, 1972a)

\begin{tabular}{|c|c|r|}
\hline Siglas & Denominação & Características da rocha \\
\hline C1 & Coerente & $\begin{array}{r}\text { Quebra com dificuldade ao golpe do martelo, produzindo } \\
\text { fragmentos de bordas cortantes. Superfície dificilmente riscável por } \\
\text { lâmina de aço. Somente escavável a fogo. }\end{array}$ \\
\hline C2 & $\begin{array}{r}\text { Moderadamente } \\
\text { coerente }\end{array}$ & $\begin{array}{r}\text { Quebra com dificuldade ao golpe do martelo. Superfície riscável } \\
\text { com lâmina de aço. Escavável a fogo. }\end{array}$ \\
C3 & Pouco coerente & $\begin{array}{r}\text { Quebra com facilidade ao golpe do martelo, produzindo fragmentos } \\
\text { que podem ser partidos manualmete. Superfície facilmente riscável } \\
\text { por lâmina de aço. Escarificável. }\end{array}$ \\
\hline C4 & Incoerente & $\begin{array}{r}\text { Quebra com a pressão dos dedos, desagregando-se. Pode ser } \\
\text { cortada com lâmina de aço. Friável e escavável com lâmina. }\end{array}$ \\
\hline
\end{tabular}

\subsubsection{Resistência}

Segundo Guidicini et al (1972a) entende-se por grau de resistência aquele relacionado com a compressão simples. Os diferentes graus de resistência são estabelecidos com base nos valores de resistência obtidos em ensaios de compressão uniaxial. Este parâmetro é muito utilizado na caracterização de maciços rochosos para fins de engenharia, e as rochas podem ser subdivididas em cinco níveis de resistência, conforme a Tabela 4.

O ensaio para obtenção da resistência a compressão uniaxial é relativamente dispendioso, requer tempo para a preparação de amostras e equipamentos especiais para a sua realização. Entretanto, testes indiretos são comumente utilizados para se obter esse parâmetro, como teste de carga puntual e o martelo de Schmidt. São testes mais simples, requerem menos preparação de amostras e equipamentos menos sofisticados.

Tabela 4 - Graus de resistência (Guidicini et al, 1972a)

\begin{tabular}{|c|c|c|}
\hline Siglas & Denominação & Resistência (MPa) \\
\hline R1 & Muito resistente & $>120$ \\
\hline R2 & Resistente & $120-60$ \\
\hline R3 & Pouco resistente & $60-30$ \\
\hline R4 & Branda & $30-10$ \\
\hline R5 & Muito Branda & $<10$ \\
\hline
\end{tabular}




\subsubsection{Ensaio de compressão puntual}

A resistência das rochas é um dos parâmetros que não pode ser obtido diretamente sem a realização de ensaios específicos de campo ou de laboratório. Entre os diferentes tipos de ensaios normalmente utilizados para este fim, o Ensaio de Compressão Puntual é um dos que necessita de equipamentos e procedimentos mais simples, tanto na preparação das amostras, como na sua execução, podendo ser realizado inclusive no canteiro de obras.

O ensaio de compressão puntual de fragmentos rochosos irregulares foi introduzido na Rússia no final da década de 50 (Guidicini et al, 1972b). Foi usado como uma forma de estimar a resistência a compressão uniaxial, parâmetro usado para determinar a resistência da rocha intacta, e tem sido largamente utilizado por sua facilidade de operação e preparação de amostra. A correlação entre o índice de carga puntual $\left(I_{s}\right)$ com a resistência a compressão uniaxial $\left(q_{u}\right)$ é obtida de forma empírica, e tem sido motivo de discussão.

D’Andrea et al (1964, apud Kaharman, 2001) realizaram testes de compressão uniaxial e de carga puntual em amostras com $25 \mathrm{~mm}$ de diâmetro, e utilizaram um modelo de regressão linear para obter a correlação entre os dois ensaios. Broch e Franklin (1972, apud Kaharman, op.cit) estabeleceram que a resistência a compressão é aproximadamente igual a 24 vezes o índice de carga puntual, referindo-se a uma amostra com 50mm de diâmetro. Para Guidicini et al, (op.cit) os parâmetros usualmente utilizados para correlacionar a resistência a compressão simples com o índice de carga puntual podem levar a grandes dispersões de resultados, ocorrendo uma grande variação dos valores de $I_{s}$ obtidos quando se variam as dimensões da amostra. Bieniawski (1975) demonstrou que a resistência a compressão uniaxial $\left(q_{u}\right)$ é aproximadamente 24 vezes o índice de carga puntual $\left(I_{s}\right)$. Nos ensaios realizados por Kaharman (op.cit) os valores obtidos no teste de carga puntual mostraram uma forte correlação com os valores de resistência a compressão das amostras ensaiadas, para um diâmetro corrigido de $50 \mathrm{~mm}\left(I_{s(50)}\right)$. 
Conforme as orientações da ISRM - International Society for Rock Mechanics (1985), o ensaio consiste no carregamento de uma amostra de rocha entre duas ponteiras cônicas até a ruptura. O Índice de Carga Puntual $\left(I_{s}\right)$ é obtido em função da carga aplicada $(Q)$ e da distância (D) entre as ponteiras, que estão aplicando a carga, no momento da ruptura. A orientação do carregamento a ser realizado é determinada pela forma da amostra (Figura 1).

Amostras de testemunhos de sondagem, com formato cilíndrico, podem ser ensaiadas com carregamento diametral, se a relação entre a largura da amostra $(L)$ e a distância entre os pontos de aplicação da carga (D) for igual ou maior a 1. O carregamento deverá ser axial, se a relação entre a espessura da amostra (W) e D for entre 0,3 e 1. Amostras irregulares ou aproximadamente cúbicas também podem ser ensaiadas, desde que a relação D/W esteja entre 0,3 e 1 , e a largura $L$ seja maior ou igual a distância $D$. O ideal é que sejam realizados pelo menos 10 ensaios, pois o índice de carga puntual é calculado através da média dos resultados, excluindo-se os dois valores mais altos e mais baixos.

DIAMETRAL

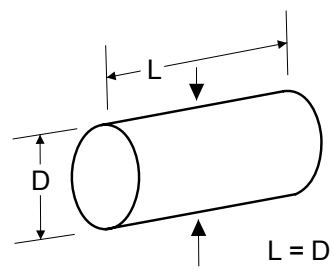

BLOCO

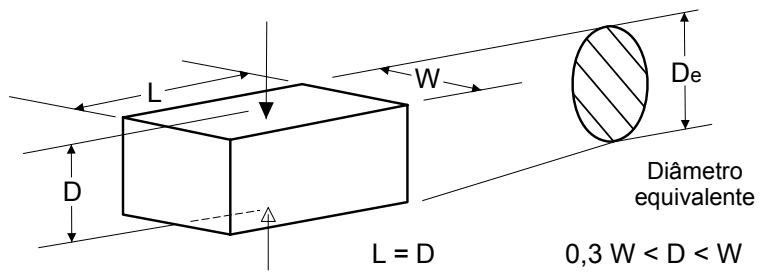

AXIAL

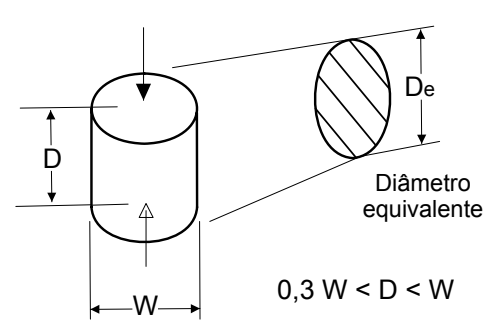

IRREGULAR

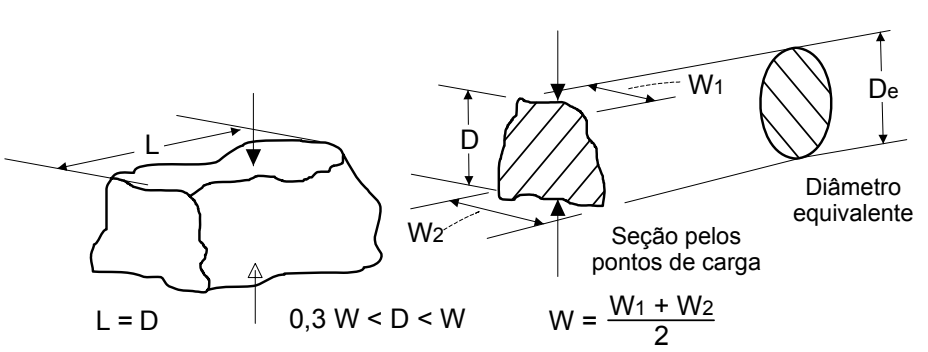

Figura 1 - Forma da amostra e tipo de ensaio de compressão puntual indicado. (ISRM, 1985) 
O índice de carga puntual $\left(I_{S}\right)$ é calculado pela equação (1), sendo $Q$ a carga requerida para romper a amostra, e $D_{e}$ o diâmetro equivalente, que é dado para ensaios diametrais pela equação (2), e corresponde à área mínima da seção transversal da amostra (minimal crosssectional area), e não a área da ruptura (Brook, 1985). Para ensaios axiais, e de amostras irregulares ou em blocos pela equação (3), onde $A=W D$.

$$
\begin{aligned}
& \mathrm{I}_{\mathrm{s}}=\mathrm{Q} / \mathrm{D}_{\mathrm{e}}^{2} \\
& \mathrm{D}_{\mathrm{e}}{ }^{2}=\mathrm{D}^{2} \\
& \mathrm{D}_{\mathrm{e}}{ }^{2}=4 \mathrm{~A} / \pi
\end{aligned}
$$

O $I_{s}$ precisa ser corrigido para o tamanho de $50 \mathrm{~mm}\left(I_{s(50)}\right)$, que é definido como o valor de $I_{s}$ que seria encontrado em um teste diametral com $D=50 \mathrm{~mm}$. A melhor maneira de se obter a correção do tamanho é plotar em um gráfico log-log as diversas relações entre $Q$ e $D_{e}{ }^{2}$, o que geralmente resulta em uma linha reta, obtendo-se desta forma, o $Q_{50}$ correspondente ao $D_{e}{ }^{2}=2500 \mathrm{~mm}^{2}$ (ou $D_{e}=50 \mathrm{~mm}$ ). O índice de carga puntual corrigido $I_{s(50)}$ é então :

$$
\mathrm{I}_{\mathrm{s}(50)}=Q_{50} / 50^{2}
$$

Quando não se dispõe de amostras suficientes para elaboração do gráfico, ou o diâmetro das amostras não varia, a correção do tamanho pode ser obtida através da equação (5), sendo $\mathrm{F}$ o fator de correção do tamanho, obtido através do gráfico da Figura 2 ou pela expressão empírica da equação (6).

$$
\begin{aligned}
& \mathrm{I}_{\mathrm{s}(50)}=\mathrm{F} \cdot \mathrm{I}_{\mathrm{s}} \\
& F=\left(D_{e} / 50\right)^{0,45}
\end{aligned}
$$




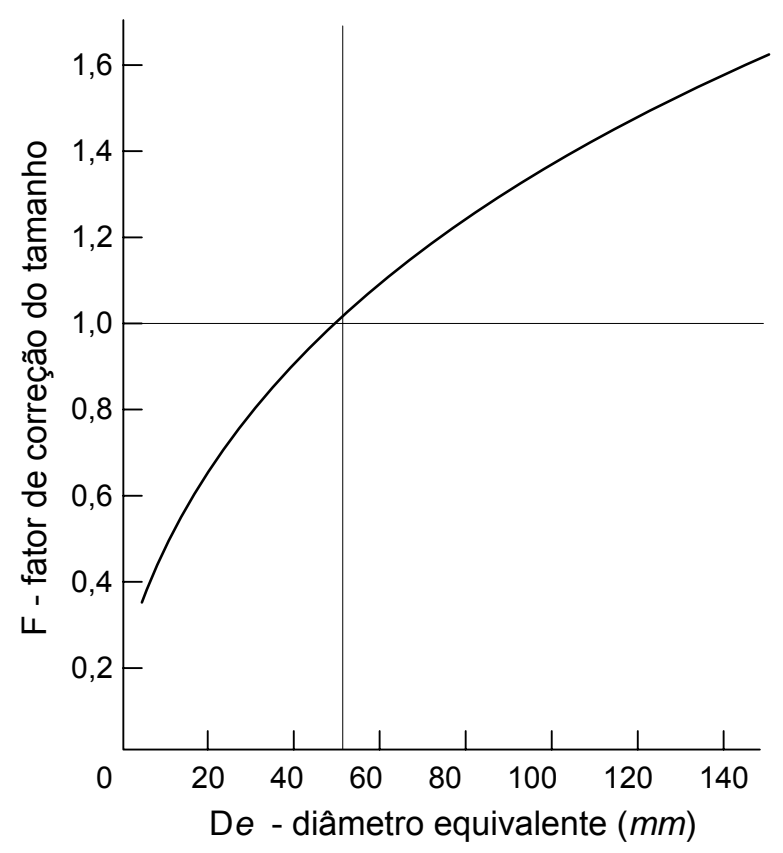

Figura 2 - Gráfico do fator de correção do tamanho. (ISRM, 1985)

O índice resistência puntual $I_{s(50)}$ pode ser usado para estimar a resistência a compressão uniaxial $\left(q_{u}\right)$, e desde que corretamente realizado é uma forma fácil e confiável de se obter a resistência da rocha. Deve-se procurar utilizar diretamente o $I_{s(50)}$ para a classificação de rochas, uma vez que correlações com a resistência a compressão uniaxial são aproximadas. Segundo a ISRM (1985) a resistência a compressão uniaxial $\left(q_{u}\right)$ corresponde a 20 à 25 vezes o índice de resistência puntual $\left(I_{s(50)}\right)$.

Durante a realização dos ensaios, pode ocorrer a penetração das ponteiras na amostra antes da ruptura, podendo resultar em uma distância final $\left(D_{f}\right)$ menor que a inicial $\left(D_{i}\right)$. Segundo a ISRM (op.cit) o erro em se assumir $\mathrm{D} f$ igual a $\mathrm{Di}$ é desprezível. Contudo se a penetração for significante, a distância a ser considerada deve ser a final. Basu e Aydin (2006) fizeram ensaios de compressão puntiforme em amostras graníticas em diferentes graus de alteração, e mediram a diferença entre as distâncias iniciais e finais das amostras. A correlação com a resistência a compressão uniaxial foi melhor para a utilização da 
distância final. Estes autores observaram ainda que a penetração das ponteiras é maior nas amostras menos alteradas.

A exemplo da utilização do ensaio de compressão puntual em estudo de caracterização geomecânica de maciço rochoso em fundação de barragem, Dobereiner et al (1987) relatam a realização dos ensaios em campo de 132 amostras de granito, que foram ensaiadas diametralmente. Segundo os autores correlacionando-se a média dos valores obtidos com os dados da compressão uniaxial, obteve-se uma relação de $q_{u}=22,4 I_{s(50)}$.

\subsubsection{Descontinuidades}

As descontinuidades são sem dúvida o principal condicionante do comportamento de um maciço. Sem elas o maciço se comportaria como rocha intacta, dependendo apenas das características intrínsecas do material, como coesão e ângulo de atrito. Mas na realidade a resistência, a deformabilidade, a estabilidade, e a permeabilidade entre outras propriedades do maciço rochoso, estão muito mais associadas à natureza das descontinuidades do que à rocha propriamente dita (Serra Júnior e Ojima, 1998).

Descontinuidade é um temo geral que engloba feições geológicas que interrompem a continuidade física do meio rochoso, como fraturas, falhas, acamamentos, contatos, foliações e xistosidades. Ela pode ser definida como qualquer superfície natural em que a resistência a tração é nula ou muito baixa (ISRM, 1978). Os principais tipos de descontinuidades são falhas e fraturas. As fraturas, ou juntas, caracterizam-se por ser um plano de quebra da continuidade da rocha sem movimentação relativa significativa entre os blocos. Um conjunto de fraturas com a mesma orientação e origem forma uma família. A falha é um plano onde ocorreu deslocamento de um bloco em relação ao outro. 
Segundo Gabrielsen (1990), qualquer pessoa que esteja trabalhando com o estudo de rochas, independentemente da escala utilizada, irá ter que lidar com descontinuidades, sejam fraturas ou falhas. Segundo o autor, as descontinuidades representam a parte mais fraca do corpo rochoso, e o local onde todos os tipos de processos geológicos (geoquímico, termal e mecânico) podem interagir.

\subsubsection{Orientação}

É a atitude de um plano de descontinuidade no espaço. É descrito pela direção e o mergulho do plano. De acordo com Magalhães e Cella (1998), a direção é definida pelo ângulo entre o norte e a linha de intercessão do plano da descontinuidade, com o plano horizontal, e o mergulho é o ângulo de inclinação do plano com o plano horizontal. A reta do mergulho é a reta de máxima inclinação no plano, perpendicular à direção.

\subsubsection{Número de famílias}

Um conjunto de descontinuidades com mesma orientação e origem caracteriza uma família de fraturas. Quando ocorre mais de uma família elas são numeradas, de acordo com o grau de importância para estudo. O conjunto das famílias de um determinado local define um sistema de fraturas.

\subsubsection{Persistência}

Segundo a ISRM (1978), a persistência implica na extensão ou dimensão de uma descontinuidade em um plano, e pode ser quantificada observando-se o comprimento do traço da descontinuidade em uma superfície exposta do maciço. As descontinuidades podem ter seus traços acabando em outras descontinuidades, ou terminando na própria rocha. De acordo com Serra Junior e Ojima (1998), "a persistência tem especial influência na resistência ao cisalhamento dos maciços rochosos, com importância decisiva em certas situações de taludes e fundações de barragens". A ISRM sugere a terminologia apresentada na Tabela 5 para a classificação da persistência das descontinuidades. 
Tabela 5 - Classificação de persistência (ISRM, 1978)

\begin{tabular}{|c|c|}
\hline Espaçamento $(\mathbf{m})$ & Descrição \\
\hline$<1$ & Persistência muito baixa \\
\hline $1-3$ & Persistência baixa \\
\hline $3-10$ & Persistência média \\
\hline $10-20$ & Persistência alta \\
\hline$>20$ & Persistência muito alta \\
\hline
\end{tabular}

Contudo, é um parâmetro difícil de ser utilizado na prática, quando não se dispõe de afloramentos extensos para a observação das descontinuidades, ou quando o estudo é feito sobre testemunhos de sondagem.

\subsubsection{Alteração das paredes das descontinuidades}

A alteração do maciço rochoso não ocorre de forma homogênea. Ela ocorre inicialmente nas áreas aflorantes do maciço, e pelas descontinuidades por onde há a possibilidade de percolação de água. A descrição da alteração das paredes é dada pelo grau de alteração da rocha, e pela espessura que a alteração apresenta.

\subsubsection{Rugosidade}

A rugosidade dos planos de uma descontinuidade é, de maneira geral, caracterizada pelas ondulações e irregularidades dos planos. De acordo com Serra Junior e Ojima (1998), a rugosidade "influência especialmente a resistência ao cisalhamento, sobretudo quando se trata de descontinuidades não preenchidas, conferindo um incremento ao ângulo de atrito, até um nível de tensões a partir do qual se verifica a ruptura." A rugosidade é quantificada de acordo com seu perfil geométrico, conforme a figura 3.
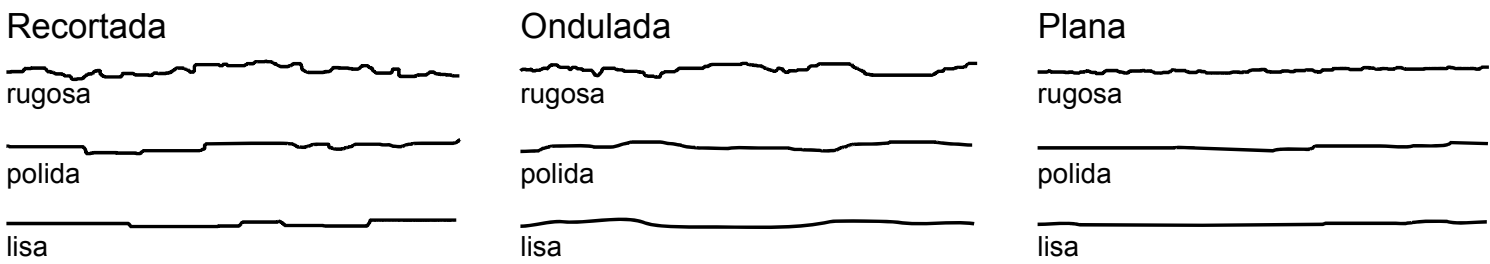

Figura 3 - Perfis de rugosidade (Barton et al. 1974 apud Serra Junior e Ojima, 1998). 


\subsubsection{Abertura}

A abertura corresponde à distância perpendicular que separa as duas paredes de uma descontinuidade, onde o espaço entre elas pode ser preenchido por ar, água ou outro material de preenchimento. A ISRM (1978) sugere a terminologia apresentada na Tabela 6 para a classificação da abertura de descontinuidades.

Tabela 6 - Classificação de aberturas de descontinuidades (ISRM, 1978)

\begin{tabular}{|c|c|c|}
\hline Abertura & Desc & \\
\hline$<0.1 \mathrm{~mm}$ & Muito apertada & \multirow{3}{*}{ Fechadas } \\
\hline $0.1-0.25 \mathrm{~mm}$ & Apertada & \\
\hline $0.25-0.5 \mathrm{~mm}$ & Parcialmente aberta & \\
\hline $0.5-2.5 \mathrm{~mm}$ & Aberta & \multirow{3}{*}{ Abertas } \\
\hline $2.5-10 \mathrm{~mm}$ & Moderadamente larga & \\
\hline$>10 \mathrm{~mm}$ & Larga & \\
\hline $1-10 \mathrm{~cm}$ & Muito larga & \multirow{3}{*}{ Afastadas } \\
\hline $10-100 \mathrm{~cm}$ & Extremamente larga & \\
\hline$>1 \mathrm{~m}$ & Cavernosa & \\
\hline
\end{tabular}

\subsubsection{Preenchimento}

Preenchimento é o termo usado para designar o material presente entre as paredes de uma descontinuidade. O tipo de preenchimento encontrado tem papel importante no comportamento do maciço rochoso, principalmente com relação à resistência ao cisalhamento e à permeabilidade. Segundo Serra Junior e Ojima (1998), a caracterização do preenchimento deve conter a espessura, a caracterização de seus constituintes (granulação, mineralogia, textura, cor) e outras informações que se mostrarem relevantes.

\subsubsection{Espaçamento}

Segundo Magalhães e Cella (1998), o espaçamento refere-se à quantidade de descontinuidades por unidade de medida. Por definição (Brown, 1981 apud Magalhães e Cella, op.cit), o espaçamento é considerado como a distância perpendicular entre duas descontinuidades de uma mesma família, geralmente se referindo à média de espaçamentos da família. A terminologia proposta pela ISRM (op.cit) é dada na Tabela 7. 
Tabela 7 - Classificação de espaçamento (ISRM, 1978)

\begin{tabular}{|c|c|}
\hline Espaçamento $(\mathbf{m m})$ & Descrição \\
\hline$<20$ & Espaçamento extremamente fechado \\
\hline $20-60$ & Espaçamento muito fechado \\
\hline $60-200$ & Espaçamento fechado \\
\hline $200-600$ & Espaçamento moderado \\
\hline $600-2000$ & Espaçamento aberto \\
\hline $2000-6000$ & Espaçamento muito aberto \\
\hline$>6000$ & Espaçamento extremamente aberto \\
\hline
\end{tabular}

\subsubsection{Grau de fraturamento}

O grau de fraturamento expressa a quantidade de fraturas por metro linear de maciço. Utilizado principalmente na descrição de testemunhos, ele difere do espaçamento por não estar relacionado à distância perpendicular entre fraturas de uma mesma família, mas reflete a quantidade de pedaços em que o maciço ficou fragmentado. Guidicini et al (1972a) propõe a classificação da Tabela 8 para determinar o grau de fraturamento.

Tabela 8 - Graus de fraturamento (Guidicini et al, 1972a)

\begin{tabular}{|c|c|c|}
\hline Siglas & Número de fraturas por metro & Denominação \\
\hline F1 & $<1$ & Ocasionalmente fraturado \\
\hline F2 & $1-5$ & Pouco fraturado \\
\hline F3 & $6-10$ & Medianamente fraturado \\
\hline F4 & $11-20$ & Muito fraturado \\
\hline F5 & $>20$ & Extremamente fraturado \\
\hline
\end{tabular}

Os métodos detalhados para descrição de descontinuidades podem ser encontrados em trabalhos da ISRM (1978), Associação Brasileira de Geologia de Engenharia e Ambiental ABGE (1983) e Serra Junior e Ojima (1998). 


\subsection{Classificação de maciços rochosos}

Segundo Hoek (2000) é nas primeiras fases de estudo de um projeto, onde ainda são poucas as informações sobre o maciço rochoso, que o uso da classificação de maciços traz grandes benefícios, e serve como um check-list que assegura que todas as informações relevantes sejam consideradas. Contudo, o autor ressalta que a utilização da classificação não deve, e nem pode, ser a única fonte de informação na elaboração do projeto.

As classificações de maciços rochosos mais sistematizadas remontam à década de quarenta, com o trabalho de Terzaghi (1946) para o projeto de suportes metálicos em túneis, onde a carga de rocha suportada era estimada com base em classificações descritivas. Hoek (op.cit) destaca as descrições dos maciços rochosos feitas na classificação de Terzaghi, onde são consideradas as características dominantes do comportamento do maciço rochoso, especialmente em condições onde a gravidade é a força dominante. Segundo Hoek (op.cit) as definições claras e concisas, e os comentários práticos incluídos em suas descrições são bons exemplos do tipo de informação que é mais útil para geologia de engenharia.

Lauffer (1958, apud Hoek op.cit.) introduziu o conceito de tempo de auto-sustentação (stand-up time) para um vão livre sem suporte, relacionado com a qualidade do maciço rochoso. Essa classificação, voltada principalmente para escavações de túneis, parte do princípio que um aumento no vão do túnel leva a uma significante redução do tempo disponível para a instalação do suporte. A classificação de Lauffer foi sendo modificada ao longo dos anos por diversos autores, e hoje é parte do método construtivo de túneis conhecido como NATM (New Australian Tunnelling Method).

Deere et al (1967, apud Hoek op.cit) propôs o RQD (rock quality designation), que descreve a qualidade de um testemunho de sondagem baseado no seu grau de fraturamento. Inicialmente desenvolvido para ser um sistema de classificação para construção de túneis e 
estimar suportes, passou a ser usado como parâmetro padrão para diversas outras classificações. Segundo Deere e Deere (1988) o RQD foi proposto em uma época onde a informação sobre a qualidade da rocha era obtida apenas por descrições geológicas dos maciços, ou através da porcentagem de recuperação de furos de sondagem.

Wickham et al (1972, apud Hoek 2000) desenvolveram um método quantitativo de descrever a qualidade de um maciço rochoso com base na classificação RSR (Rock Structure Rating), e introduzem o conceito de classificar os maciços a partir de notas atribuídas a cada uma de suas características, definindo um valor numérico total (RSR) para cada classe. Os parâmetros avaliados nesta classificação incluem a geologia do maciço (tipo de rocha, dureza e estruturas), a geometria das descontinuidades (espaçamento, orientação e relação com a direção da escavação) e o efeito da ação das águas subterrâneas.

Em 1973 Bieniawski desenvolve o Sistema RMR, enquanto Barton et al em 1974 desenvolvem Sistema Q. Ambos utilizam a idéia de classificação do maciço com atribuição de notas, e se baseiam na experiência obtida em casos históricos. São os sistemas de classificação geomecânica mais utilizados até hoje, e serão vistos em maior detalhe nos itens 2.4.2 e 2.4.3.

Segundo Guidicini et al (1972a) uma classificação geotécnica de meios rochosos depende do campo de aplicação da obra (superficial ou subterrânea), da etapa de projeto e o nível de detalhe do estudo, da disponibilidade de recursos, do grau de desenvolvimento do meio técnico em que a classificação é feita, e da natureza do meio rochoso em estudo e seu nível de complexidade.

Segundo Osgood et al (1975, apud Serra Junior e Ojima 1998) um sistema de classificação que adota critérios científicos deve fornecer dados verificáveis e reproduzíveis, compatíveis com dados produzidos por outro método, sensível às ordens de grandeza do fenômeno 
estudado, podendo ser aplicado a todo tipo de combinações do fenômeno e fornecendo informações relevantes ao estudo.

Para Bieniawski (1976), as classificações de maciços rochosos são necessárias para avaliar as condições dos maciços para fins de engenharia, e se tornaram bem aceitas pela comunidade científica, pois permitem correlacionar as experiências de condições de maciços de um local com as encontradas em outro. Nenhum parâmetro isolado pode descrever completa e adequadamente um maciço rochoso para fins de engenharia. Vários fatores têm diferentes significados, e somente uma combinação de fatores pode descrever um maciço satisfatoriamente. Para selecionar os parâmetros geológicos é importante que eles sejam não só os mais significativos do ponto de vista da engenharia, mas também que possam ser medidos e verificadas no campo, a fim de evitar opiniões pessoais e observações qualitativas.

Os sistemas classificatórios se dividem em duas categorias, segundo Nieble e Francis (1976), uma que considera o meio rochoso independente da sua utilização, e outra que considera o tipo de obra em questão. Segundo Kirkaldie (1988), muitos dos problemas que surgiram no passado com os sistemas de classificação devem-se ao caráter genérico das classificações, com a rocha sendo classificada comumente por suas características mineralógicas e petrológicas, sendo que nessas classificações a rocha precisava ser reinterpretada para os diferentes usos na engenharia.

As classificações devem conter as seguintes características gerais segundo Pincus (1988): deve ser completa, isto é, todos os itens relevantes devem constar na classificação; as categorias devem ser mutuamente exclusivas, ou seja, cada item a ser classificado deve constar em apenas uma categoria; e o critério usado para a distinção das categorias deve ser aplicado em toda a classificação. 
Segundo Monticeli (1983), a compartimentação geológico-geotécnica em projetos de fundação de barragens, tem por finalidade o levantamento das condições de fundação das obras, sendo que também são utilizados para estudos de áreas de empréstimo, estabilidade de taludes e aberturas de canais e túneis. As preocupações básicas são a determinação da capacidade de carga dos solos e das rochas, as suas características de resistência aos processos convencionais de escavação e os aspectos gerais da permeabilidade dos materiais, principalmente referentes à sua estanqueidade. A compartimentação de maciços rochosos pode ser feita através de unidades geológico-geotécnicas ou de classes de maciços, sendo para isso realizada investigações de superfície, sub-superfície e ensaios de laboratório condizentes com as necessidades do projeto.

Segundo Ojima (1982) os sistemas classificadores utilizados em maciços rochosos podem ser reunidos em dois grupos: as classificações que visam propor uma linguagem comum entre os técnicos, interessando apenas a descrição das propriedades intrínsecas do meio rochoso; e as classificações que visam a previsão do comportamento do maciço frente a determinados tipos de solicitações e reações. Ojima (op.cit) considera que não tem sentido a procura por uma classificação universal, o que deve ter um caráter universal é a metodologia, permitindo elaborar uma classificação adequada para cada conjunto de situações.

As metodologias clássicas de classificação de maciços rochosos apresentam resultados interessantes para obras subterrâneas, mas nem sempre retratam convenientemente as necessidades de projeto, quando se trata de fundações (Monticeli, op.cit). O autor sugere a classificação utilizada pelo Instituto de Pesquisas Tecnológicas do Estado de São Paulo IPT, que considera os graus de alteração e de fraturamento como parâmetros para estabelecer as classes do maciço. Destaca ainda, para a classificação de fundações de barragens, as propostas de caracterização geotécnica de Guidicini et al (1972a) que leva em consideração a classificação genética da rocha, grau de alteração, resistência, coerência, 
grau e tipo de fraturamento; de lida et al (1970, apud Monticeli 1983), que consideram a coerência ou alteração da rocha, o grau de fraturamento e a condição das juntas; e Camargo et al (1978), que estabelecem compartimentos geomecânicos a partir de várias etapas de análise e de síntese de informações disponíveis.

A conceituação de termos como caracterização, classificação geológico-geotécnica, classificação geomecânica e compartimentação, são definidos por Monticeli (op.cit) como:

Caracterização de Maciço Rochoso: levantamento das características geológicas (litologia e estruturas), geotécnicas (recuperação, fraturamento, alteração, etc) e mecânicas (obtidos através de ensaios) do maciço rochoso.

Classificação Geológico-Geotécnica: elege características representativas do maciço (parâmetros de classificação) com os quais se estabelecem unidades, zonas ou compartimentos, que correspondem às classes formadas pelas variações dos parâmetros.

Classificação Geomecânica ou Modelo Geomecânico: estabelece parâmetros ou índices mecânicos às classes ou unidades de maciço, para utilização direta no projeto.

Compartimentação: estabelece unidades que sintetizam de maneira clara e relevante os condicionantes geológicos-geotécnicos importantes para a finalidade do estudo, que podem ser obtidos a partir da caracterização ou da classificação do maciço rochoso.

Nieble e Francis (1976) consideram como caracterização do maciço rochoso a coleta de todas as informações, sejam elas feições litológicas, estruturais, índices e propriedades físicas, enquanto que a classificação coleta apenas as informações definidas como critérios pelo sistema utilizado. 


\subsubsection{Rock Quality Designation - RQD}

O RQD inicialmente introduzido por Deere et al (1967, apud Serra Junior e Ojima, 1998) como uma forma de classificação de maciços rochosos, acabou se tornando um dos parâmetros utilizados por outras classificações. É definido como a percentagem de pedaços de testemunho de rocha intactos, maiores ou iguais a $10 \mathrm{~cm}$, pelo comprimento do avanço da perfuração, a manobra. Para isto, o testemunho deve ter tamanho mínimo NW $(54,7 \mathrm{~mm})$ e ser perfurado com barrilete duplo-livres, para rochas duras a medianamente duras:

$$
R Q D=\sum \frac{p}{n} \times 100
$$

$p=$ comprimento das peças maiores que $10 \mathrm{~cm}$;

$\mathrm{n}$ = comprimento da manobra de avanço da perfuração.

No Brasil utiliza-se uma variação do RQD, o IQR (Índice de Qualidade da Rocha), que utiliza os comprimentos dos trechos com espaçamento homogêneo de descontinuidades, com comprimento mínimo de 0,5 metros, ao invés de considerar o comprimento total da manobra (Serra Junior e Ojima, 1998).

\subsubsection{Classificação de Barton - Sistema $Q$}

O sistema $Q$ de classificação de maciço rochoso foi desenvolvido por Barton, Lien e Lunde em 1974, baseados na análise de 212 casos históricos de túneis, dos quais mais de 30 casos incluíam túneis permanentemente sem suportes. Este sistema avalia numericamente a qualidade do maciço rochoso usando os seguintes parâmetros: RQD; número de famílias de juntas; rugosidade das juntas; grau de alteração e preenchimento das juntas; fluxo interno d'água; e condições de tensões. 
Estes parâmetros se relacionam através da equação:

$$
Q=\frac{R Q D}{J n} \times \frac{J r}{J a} \times \frac{J w}{S R F}
$$

Onde:

$\mathrm{RQD}$ - rock quality designation (Tabela 9);

Jn - índice de influência do número de famílias de fraturas (Tabela 10);

$\mathrm{Jr}$ - índice de influência da rugosidade das paredes das fraturas (Tabela 11);

Ja - índice de influência da alteração das paredes das fraturas (Tabela 12);

Jw - índice de influência da ação da água subterrânea (Tabela 13);

SRF - índice de influência do estado de tensão do maciço (Tabela 14).

$\mathrm{Na}$ equação número 8 , o primeiro termo expressa a relação de dimensão dos blocos, o segundo, a resistência ao cisalhamento ao longo das superfícies das descontinuidades, e o terceiro as tensões atuantes. O índice para os coeficientes de rugosidade (Jr) e de alteração (Ja) deve ser analisado para a família de descontinuidades que se apresente na condição mais desfavorável à estabilidade. A nota final obtida para o maciço pode variar entre 0,001 até 1000 , abrangendo as diversas variações dos maciços rochosos. Com a nota final podese relacionar o maciço à uma das nove classes, conforme a tabela 15.

O objetivo do sistema Q é determinar o tipo de suporte necessário para um túnel, a partir da relação entre a classificação do maciço, a dimensão do vão e a finalidade do túnel. Essa relação determina 38 categorias para as quais são propostos os tipos de suporte necessários. 
Tabela 9 - Valores de RQD - Classificação geomecânica de BARTON et al, (1974).

\begin{tabular}{|c|c|c|}
\hline \multicolumn{2}{|c|}{ Padrão Geomecânico do Maciço (\%) } & RQD \\
\hline A & Muito ruim & $0-25^{*}$ \\
\hline B & Ruim & $25-50$ \\
\hline C & Regular & $50-70$ \\
\hline D & Bom & $75-90$ \\
\hline E & Excelente & $90-100$ \\
\hline
\end{tabular}

* Para RQD < 10, adotar um valor nominal igual a 10.

Tabela 10 - Valores de Jn - Classificação geomecânica de BARTON et al, (1974).

\begin{tabular}{|c|c|c|}
\hline \multicolumn{2}{|c|}{ Condições de Compartimentação do Maciço } & Jn \\
\hline A & Fraturas esparsas ou ausentes & $0,5-1,0$ \\
\hline B & Uma família de fraturas & 2 \\
\hline C & B + fraturas esparsas & 3 \\
\hline D & Duas famílias de fraturas & 4 \\
\hline E & D + fraturas esparsas & 6 \\
\hline F & Três famílias de fraturas & 9 \\
\hline G & F + fraturas esparsas & 12 \\
\hline H & Muito fraturado, 4 ou + fraturas & 15 \\
\hline I & Rocha completamente fragmentada & 20 \\
\hline
\end{tabular}

Obs.: Para intersecções, usar $3 \mathrm{Jn}$ e, para emboques, $2 \mathrm{Jn}$

Tabela 11 - Valores de Jr - Classificação geomecânica de BARTON et al, (1974).

\begin{tabular}{|c|c|c|}
\hline \multicolumn{3}{|c|}{ Condições de Rugosidade das Paredes } \\
\hline \multicolumn{3}{|c|}{$\begin{array}{c}\text { Contato rocha-rocha, sem deslocamento relativo entre as paredes } \\
\text { (deslocamento diferencial < 10cm) }\end{array}$} \\
\hline A & Fraturas não persistentes & 4 \\
\hline B & Fraturas rugosas ou irregulares, onduladas & 3 \\
\hline D & Fraturas lisas, onduladas & 2 \\
\hline E & Fraturas polidas, onduladas & 1,5 \\
\hline F & Fraturas rugosas ou irregulares, planas & 1,5 \\
\hline G & Fraturas lisas, planas & 1,0 \\
\hline & Fraturas polidas ou estriadas, planas & 0,5 \\
\hline H & Fraturas sem contato rocha-rocha e com deslocamento relativo entre as paredes \\
\hline I & Fraturas preenchidas com material argiloso & 1,0 \\
\hline
\end{tabular}


Tabela 12 - Valores de Ja - Classificação geomecânica de BARTON et al, (1974).

Condições de Alteração das Paredes

$\mathrm{Ja}$

$\varnothing r^{*}$

Fraturas com contato rocha-rocha e sem deslocamento relativo entre as paredes

\begin{tabular}{|c|c|cc|}
\hline A & $\begin{array}{c}\text { Paredes duras, compactas, preenchimento de materiais } \\
\text { impermeáveis }\end{array}$ & 0,75 & - \\
\hline B & Paredes sem alteração, pigmentação superficial incipiente & 1,0 & $25-35^{\circ}$ \\
\hline C & Paredes levemente alteradas & 2,0 & $25-30^{\circ}$ \\
\hline D & Paredes com películas de material silto-arenoso com fração argilosa & 3,0 & $20-25^{\circ}$ \\
\hline E & Paredes com películas de material mole, eventualmente minerais \\
expansivos & 4,0 & $8-16^{\circ}$ \\
\hline
\end{tabular}

Fraturas com contato rocha-rocha e deslocamento relativo incipiente entre as paredes $(<10 \mathrm{~cm})$

\begin{tabular}{|c|c|cc|}
\hline F & Paredes com partículas arenosas, fragmentas de rocha, etc. & 4,0 & $25-30^{\circ}$ \\
\hline G & $\begin{array}{c}\text { Paredes com preenchimentos continuas e pouco espessos }(<5 \mathrm{~mm}) \\
\text { de material argiloso forte mente sobre adensado }\end{array}$ & 6,0 & $16-24^{\circ}$ \\
\hline H & $\begin{array}{c}\text { Paredes com preenchimentos continuas e pouco espessos }(<5 \mathrm{~mm}) \\
\text { de material argiloso pouco/medianamente sobre adensado }\end{array}$ & 8,0 & $12-16^{\circ}$ \\
\hline J & Paredes com preenchimento de materiais argilosos expansivos & $8-12$ & $6-12^{\circ}$ \\
\hline \multicolumn{5}{|c|}{ Fraturas sem contato rocha-rocha e com deslocamento relativo entre as paredes } \\
\hline K & $\begin{array}{c}\text { Zonas de preenchimento com fragmentas de rocha e material } \\
\text { argiloso (ver G, H e J para caracterizar as argilas) }\end{array}$ & $\begin{array}{c}6,8 \\
8-12\end{array}$ & $6-12^{\circ}$ \\
\hline L & Zonas de preenchimento com material areno ou silto-argiloso & 5,0 & - \\
\hline M & Zonas de preenchimento com material argiloso (ver G, H e J para & 10,13 & $6-24^{\circ}$ \\
\hline
\end{tabular}

* Ângulo de atrito residual (indicativo das propriedades mineralógicas dos produtos de alteração)

Tabela 13 - Valores de Jw - Classificação geomecânica de BARTON et al, (1974).

\begin{tabular}{|c|c|c|c|}
\hline \multicolumn{2}{|r|}{ Condições de Afluência da Água } & Jw & $\begin{array}{c}\mu^{*} \\
\left(\mathrm{Kgf} / \mathrm{cm}^{2}\right)\end{array}$ \\
\hline A & Escavação a seco ou com pequena afluência de água $<5 \mathrm{l} / \mathrm{min}$ & 1,0 & $<1,0$ \\
\hline B & $\begin{array}{l}\text { Afluência média de água com eventual carreamento do } \\
\text { preenchimento }\end{array}$ & 0,66 & $1,0-2,5$ \\
\hline C & $\begin{array}{l}\text { Afluência elevada de água em rochas competentes de fraturas não } \\
\text { reenchidas }\end{array}$ & 0,5 & $2,5-10,0$ \\
\hline $\mathrm{D}$ & Afluência elevada de água com carreamento do preenchimento & 0,33 & $2,5-10,0$ \\
\hline $\mathrm{E}$ & $\begin{array}{l}\text { Afluência excepcionalmente elevada de água, decaindo com o } \\
\text { tempo }\end{array}$ & $0,1-0,2$ & $>10$ \\
\hline $\mathrm{F}$ & $\begin{array}{l}\text { Afluência excepcionalmente elevada de água, sem decaimento com } \\
\text { o tempo }\end{array}$ & $0,05-0,1$ & $>10$ \\
\hline
\end{tabular}

*Valores aproximados das pressões de água intersticial. 
Tabela 14 - Valores de SRF - Classificação geomecânica de BARTON et al, (1974).

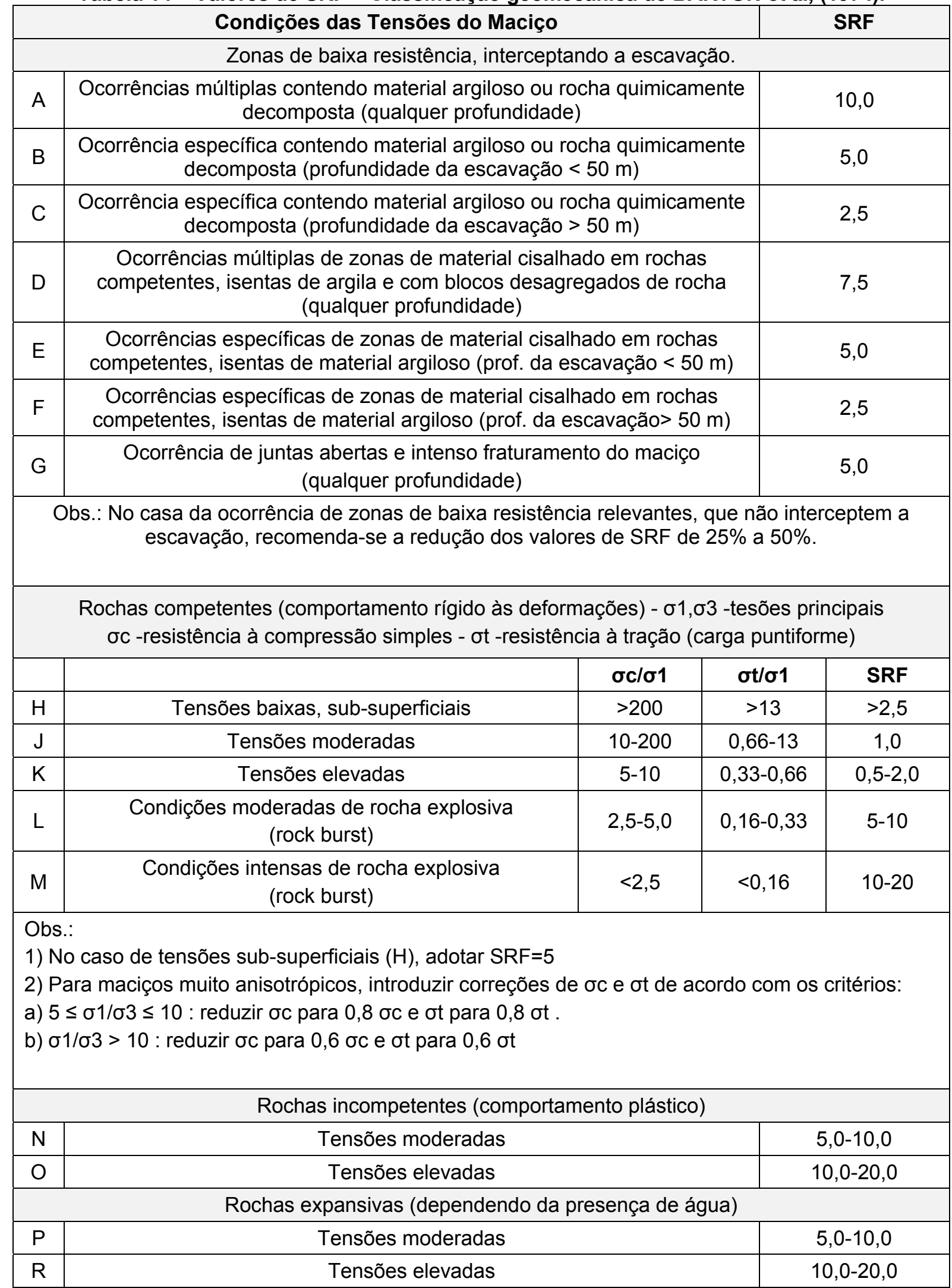


Tabela 15 - Classes de maciços rochosos - Sistema Q (BARTON et al, 1974).

\begin{tabular}{|c|c|}
\hline Padrão Geomecânico do Maciço & Valores de $\mathbf{Q}$ \\
\hline Péssimo (excepcionalmente ruim) & $<0,01$ \\
\hline Extremamente ruim & $0,01-0,1$ \\
\hline Muito ruim & $0,1-1,0$ \\
\hline Ruim & $1,0-4,0$ \\
\hline Regular & $4,0-10,0$ \\
\hline Bom & $10,0-40,0$ \\
\hline Muito bom & $40,0-100,0$ \\
\hline Ótimo (extremamente bom) & $100,0-400,0$ \\
\hline Excelente (excepcionalmente bom) & $>400,0$ \\
\hline
\end{tabular}

\subsubsection{Classificação de Bieniawski - Sistema RMR}

Desenvolvido por Bieniawski em 1973, o sistema RMR (Rock Mass Rating), também conhecido como classificação geomecânica, foi sendo modificado com a inclusão de novos parâmetros, sendo hoje utilizada a classificação publicada em 1989. É baseada em seis parâmetros: resistência da rocha intacta; RQD; espaçamento de fraturas; condição das fraturas; água subterrânea; e orientação das descontinuidades.

Para aplicar a classificação geomecânica o maciço rochoso é dividido primeiramente em regiões estruturais, onde as características sejam mais ou menos uniformes, e a classificação é aplicada para cada região considerando as características médias de cada uma (Bieniawski, 1979). Para cada um dos parâmetros é atribuído um peso relativo, de acordo com a Tabela 16. O sexto parâmetro é um valor de ajuste que avalia a relação da orientação das descontinuidades com o tipo de obra, podendo ser mais ou menos favorável. A Tabela 17 exemplifica o efeito das orientações das descontinuidades em relação ao eixo e sentidos de escavação em túneis, enquanto a Tabela 18 (Bieniawski e Orr, 1976) auxilia na estimativa da favorabildade da orientação das descontinuidades em relação à estabilidade de fundações de barragens. A Tabela 19 detalha os critérios para descrição das condições das descontinuidades. A nota final do maciço é dada pela somatória dos pesos dos 
parâmetros considerados, definindo as classes de maciços (Tabela 20). O sistema RMR associa ao final, para cada uma das cinco classes de maciço rochoso, uma estimativa do tempo médio de auto sustentação e vão livre da seção para o caso de túneis, e os valores de coesão (KPa) e de ângulo de atrito (Tabela 21).

Tabela 16 - Classificação geomecânica de Bieniawski (1989).

\begin{tabular}{|c|c|c|c|c|c|c|c|c|c|c|}
\hline \multicolumn{4}{|c|}{ PARÂMETROS } & \multicolumn{7}{|c|}{ FAIXA DE VALORES } \\
\hline \multirow{3}{*}{1} & \multirow{2}{*}{ 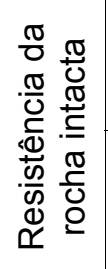 } & \multirow{2}{*}{\multicolumn{2}{|c|}{$\begin{array}{c}\begin{array}{c}\text { Índice } \\
\text { puntiforme }\end{array} \\
\begin{array}{c}\text { Compressão } \\
\text { simples (MPa) }\end{array}\end{array}$}} & \multirow{2}{*}{$\begin{array}{l}>10 \\
>250\end{array}$} & \multirow{2}{*}{$\begin{array}{c}4 \text { a } 10 \\
100 \text { a } 250\end{array}$} & \multirow{2}{*}{$\begin{array}{c}2 \text { a } 4 \\
50 \text { a } 100\end{array}$} & \multirow{2}{*}{$\begin{array}{c}1 \text { a } 2 \\
25 \text { a } 50\end{array}$} & \multicolumn{3}{|c|}{$\begin{array}{l}\text { Utilizar } \\
\text { compressão } \\
\text { simples }\end{array}$} \\
\hline & & & & & & & & $\begin{array}{l}5 a \\
25\end{array}$ & $\begin{array}{c}1 \mathrm{a} \\
5\end{array}$ & $<1$ \\
\hline & \multicolumn{3}{|c|}{ Peso relativo } & 15 & 12 & 7 & 4 & 2 & 1 & 0 \\
\hline \multirow{2}{*}{2} & \multicolumn{3}{|c|}{ RQD } & 90 a 100 & 75 a 90 & 50 a 75 & 25 a 50 & & $<25$ & \\
\hline & \multicolumn{3}{|c|}{ Peso relativo } & 20 & 17 & 13 & 8 & & 5 & \\
\hline \multirow[t]{2}{*}{3} & \multicolumn{3}{|c|}{$\begin{array}{l}\text { Espaçamento das } \\
\text { fraturas }\end{array}$} & $>2 m$ & 0,6 a $2 m$ & $\begin{array}{c}200 \text { a } 600 \\
\mathrm{~mm}\end{array}$ & 60 a $200 \mathrm{~mm}$ & & $60 \mathrm{mn}$ & \\
\hline & \multicolumn{3}{|c|}{ Peso relativo } & 20 & 15 & 10 & 8 & & 5 & \\
\hline \multirow[t]{2}{*}{4} & \multicolumn{3}{|c|}{$\begin{array}{l}\text { Condição das } \\
\text { fraturas }\end{array}$} & $\begin{array}{l}\text { Superfícies } \\
\text { muito } \\
\text { rugosas; } \\
\text { não } \\
\text { contínuas; } \\
\text { fechadas; } \\
\text { paredes } \\
\text { duras }\end{array}$ & $\begin{array}{l}\text { Superfícies } \\
\text { pouco } \\
\text { rugosas; } \\
\text { abertura } \\
<1 \mathrm{~mm} ; \\
\text { paredes } \\
\text { duras }\end{array}$ & $\begin{array}{l}\text { Superfícies } \\
\text { pouco } \\
\text { rugosas; } \\
\text { abertura } \\
<1 \mathrm{~mm} ; \\
\text { paredes } \\
\text { moles }\end{array}$ & $\begin{array}{c}\text { Superfícies } \\
\text { estriadas ou } \\
\text { preenchimento } \\
<5 \mathrm{~mm} \text { ou } \\
\text { abertura } 1-5 \\
\text { mm; contínuas }\end{array}$ & $\begin{array}{r}\text { Pree } \\
\text { mol } \\
\text { ou a } \\
\text { mm; }\end{array}$ & $\begin{array}{l}\text { nchim } \\
\text { e }>5 r \\
\text { jerturé } \\
\text { contín }\end{array}$ & $\begin{array}{l}\text { ento } \\
\mathrm{nm} \\
\mathrm{a}>5 \\
\text { uas }\end{array}$ \\
\hline & \multicolumn{3}{|c|}{ Peso relativo } & 30 & 25 & 20 & 10 & & 0 & \\
\hline \multirow{4}{*}{5} & \multirow{3}{*}{ 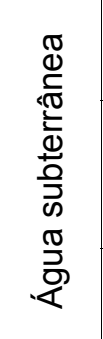 } & \multicolumn{2}{|c|}{$\begin{array}{l}\text { Infiltração em } \\
\text { 10m de túnel }\end{array}$} & $\begin{array}{l}\text { Nenhuma } \\
\text { (ou) }\end{array}$ & $\begin{array}{c}<10 \mathrm{l} / \mathrm{min} \\
\quad(\mathrm{ou})\end{array}$ & $\begin{array}{l}<25 \mathrm{l} / \mathrm{min} \\
\text { (ou) }\end{array}$ & $\begin{array}{c}25 \text { a } 125 \mathrm{l} / \mathrm{min} \\
\text { (ou) }\end{array}$ & \multicolumn{3}{|c|}{$\begin{array}{l}>125 \mathrm{l} / \mathrm{min} \\
\text { (ou) }\end{array}$} \\
\hline & & \multicolumn{2}{|c|}{$\begin{array}{c}\text { Relação } \\
\text { (pressão de } \\
\text { água / tensão) }\end{array}$} & $\begin{array}{c}0 \\
\text { (ou) }\end{array}$ & $\begin{array}{l}<0,1 \\
\text { (ou) }\end{array}$ & $\begin{array}{c}0,1 \text { a } 0,2 \\
\text { (ou) }\end{array}$ & $\begin{array}{c}0,2 \text { a } 0,5 \\
\text { (ou) }\end{array}$ & & $\begin{array}{l}>0,5 \\
\text { (ou) }\end{array}$ & \\
\hline & & \multicolumn{2}{|c|}{$\begin{array}{l}\text { Condições } \\
\text { gerais }\end{array}$} & Seco & Umedecido & Úmido & Gotejando & \multicolumn{3}{|c|}{ Com fluxo } \\
\hline & \multicolumn{3}{|c|}{ Peso relativo } & 15 & 10 & 7 & 4 & \multicolumn{3}{|c|}{0} \\
\hline \multirow{4}{*}{6} & \multicolumn{3}{|c|}{ Direção e mergulho } & $\begin{array}{c}\text { Muito } \\
\text { favorável }\end{array}$ & Favorável & Moderado & Desfavorável & \multicolumn{3}{|c|}{$\begin{array}{c}\text { Muito } \\
\text { desfavorável }\end{array}$} \\
\hline & \multirow{3}{*}{\multicolumn{2}{|c|}{$\begin{array}{l}\text { Peso } \\
\text { relativo }\end{array}$}} & Túneis & 0 & -2 & -5 & -10 & \multicolumn{3}{|c|}{-12} \\
\hline & & & Fundações & 0 & -2 & -7 & -15 & & -50 & \\
\hline & & & Taludes & 0 & -2 & -25 & -50 & & -60 & \\
\hline
\end{tabular}


Tabela 17 - Efeito da direção geológica e do mergulho na construção de túneis

\begin{tabular}{|c|c|c|c|}
\hline \multicolumn{2}{|c|}{ Direção perpendicular ao eixo do túnel } & \multicolumn{2}{|c|}{$\begin{array}{c}\text { Direção paralela ao eixo } \\
\text { do túnel }\end{array}$} \\
\hline $\begin{array}{l}\text { Escavação no sentido do } \\
\text { mergulho (Mergulho } 45 \text { a 90) }\end{array}$ & $\begin{array}{l}\text { Escavação no sentido do } \\
\text { mergulho (Mergulho } 20 \text { a } 45^{\circ} \text { ) }\end{array}$ & $\begin{array}{l}\text { Mergulho } \\
45 \text { a } 90^{\circ}\end{array}$ & $\begin{array}{l}\text { Mergulho } \\
20 \text { a } 45^{\circ}\end{array}$ \\
\hline Muito favorável & Favorável & $\begin{array}{c}\text { Muito } \\
\text { desfavorável }\end{array}$ & Moderado \\
\hline $\begin{array}{l}\text { Escavação contra o mergulho } \\
\left(\text { Mergulho } 45 \text { a } 90^{\circ}\right)\end{array}$ & $\begin{array}{c}\text { Escavação contra o mergulho } \\
\left(\text { Mergulho } 20 \text { a } 45^{\circ}\right)\end{array}$ & \multicolumn{2}{|c|}{$\begin{array}{l}\text { Mergulho de } 0 \text { a } 20^{\circ} \\
\text { com direção qualquer }\end{array}$} \\
\hline Moderado & Desfavorável & \multicolumn{2}{|c|}{ Moderado } \\
\hline
\end{tabular}

Tabela 18 - Efeito da direção geológica em fundações de barragens (Bieniawski e Orr, 1976).

\begin{tabular}{|c|c|c|c|c|}
\hline $\begin{array}{c}\text { Mergulho entre } \\
0^{\circ} \text { e } 10^{\circ}\end{array}$ & \multicolumn{2}{|c|}{ Mergulho entre $10^{\circ}$ e $30^{\circ}$} & $\begin{array}{c}\text { Mergulho entre } \\
30^{\circ} \text { e } 60^{\circ}\end{array}$ & $\begin{array}{c}\text { Mergulho entre } \\
60^{\circ} \text { e } 90^{\circ}\end{array}$ \\
\cline { 2 - 5 } & Montante & Jusante & Favorável & Muito desfavorável \\
\hline Muito favorável & Desfavorável & Moderado & Favola \\
\hline
\end{tabular}

Tabela 19 - Orientação para a classificação das condições das descontinuidades.

\begin{tabular}{|c|c|c|c|c|c|}
\hline Parâmetro & \multicolumn{5}{|c|}{ FAIXA DE VALORES } \\
\hline $\begin{array}{c}\text { Persistência da } \\
\text { descontinuidade }\end{array}$ & $<1 \mathrm{~m}$ & $1 \mathrm{a} 3 \mathrm{~m}$ & $3 \mathrm{a} 10 \mathrm{~m}$ & $10 \mathrm{a} 20 \mathrm{~m}$ & $>20 \mathrm{~m}$ \\
\hline Peso relativo & 6 & 4 & 2 & 1 & 0 \\
\hline Abertura & Nenhuma & $<0,1 \mathrm{~mm}$ & $0,1 \mathrm{a} 1 \mathrm{~mm}$ & $1 \mathrm{a} 5 \mathrm{~mm}$ & $>5 \mathrm{~mm}$ \\
\hline Peso relativo & 6 & 5 & 4 & 1 & 0 \\
\hline Rugosidade & Muito rugosa & Rugosa & $\begin{array}{c}\text { Levemente } \\
\text { rugosa }\end{array}$ & Lisa & $\begin{array}{c}\text { Espelho de } \\
\text { falha }\end{array}$ \\
\hline Peso relativo & 6 & 5 & 3 & 1 & 0 \\
\hline Preenchimento & \multicolumn{2}{|c|}{ Preenchimento duro } & & Preenchimento mole \\
\cline { 2 - 7 } & Nenhum & $<5 \mathrm{~mm}$ & $>5 \mathrm{~mm}$ & $<5 \mathrm{~mm}$ & $>5 \mathrm{~mm}$ \\
\hline Peso relativo & 6 & 4 & 2 & 2 & 0 \\
\hline Alteração & Nenhuma & Leve & Moderada & Alta & Decomposta \\
\hline Peso relativo & 6 & 5 & 3 & 1 & 0 \\
\hline
\end{tabular}

Tabela 20 - Classes do maciço determinada pela soma total dos pesos.

\begin{tabular}{|c|c|c|c|c|c|}
\hline Classe & I & II & III & IV & V \\
\hline Descrição & Muito bom & Bom & Regular & Pobre & Muito pobre \\
\hline Soma dos Pesos & 100 a 81 & 80 a 61 & 60 a 41 & 40 a 21 & $>20$ \\
\hline
\end{tabular}

Tabela 21 - Significado das classes.

\begin{tabular}{|c|c|c|c|c|c|}
\hline Classe & I & II & III & IV & V \\
\hline $\begin{array}{l}\text { Tempo médio de } \\
\text { auto sustentação }\end{array}$ & 10 anos & 6 meses & 1 semana & 5 horas & 10 minutos \\
\hline Vão da seção & $15 \mathrm{~m}$ & $10 \mathrm{~m}$ & $5 \mathrm{~m}$ & $2,5 \mathrm{~m}$ & $1 \mathrm{~m}$ \\
\hline Coesão $(\mathrm{KPa})$ & $>400$ & 400 a 300 & 300 a 200 & 200 a 100 & $<100$ \\
\hline Ângulo de atrito & $>45^{\circ}$ & 35 a $45^{\circ}$ & 25 a $35^{\circ}$ & 15 a $25^{\circ}$ & $<15^{\circ}$ \\
\hline
\end{tabular}


Segundo Bieniawski (1988), o RMR é um sistema de aplicação simples, e os parâmetros utilizados são facilmente obtidos em furos de sondagem ou em mapeamentos geológicos. O autor não recomenda utilizar a classificação caso não se disponha de todos os dados, e sugere aplicar no mínimo duas classificações no desenvolvimento de um projeto, com a finalidade de checar os resultados obtidos.

Kirsten (1988), em discussão sobre o sistema RMR afirma que o sistema não é suficientemente sensível com relação a parâmetros individuais, exemplificando com uma situação hipotética, um maciço classificado como Bom, com uma nota de 79 pontos, e simulando uma situação pior com o mesmo maciço, apenas alterando as condições das descontinuidades, onde ele obtém uma nota 62 , e continua com a mesma classificação, Bom.

Sen e Sadagah (2003) propõem a determinação dos valores de RMR de maneira contínua para a variação dos parâmetros, sem a divisão em classes de valores. Para isso utilizam gráficos que relacionam os valores dos parâmetros com seus respectivos pesos relativos. A partir destes gráficos, os autores propõem uma série de equações com as quais podem ser obtidos os valores de pesos relativos. Da mesma forma, os autores propõem a determinação da estimativa do tempo médio de auto sustentação (t), do vão livre da seção $(S)$, da coesão $(C)$ e do ângulo de atrito $(\theta)$ :

$$
\begin{gathered}
t=1,19 e^{0,178 \cdot R M R} \\
S=R M R / 18 \\
C=3,625 . R M R \\
\theta= \begin{cases}25[1+0,01 R M R] & \text { para } R M R \geq 20 \\
1,5 R M R & \text { para } R M R \leq 20\end{cases}
\end{gathered}
$$


Para o estudo de fundações a determinação do módulo de deformabilidade $\left(E_{M}\right)$ é de grande importância, e pode ser estimado através de correlações com o valor de RMR do maciço. A equação 12 é dada para valores de RMR maiores que 50 (Bieniawski, 1989), e a equação 13 (Serafim e Pereira, 1983) é dada para valores de RMR menores que 50 , sendo $E_{M}$ dado em GPa.

$$
\begin{aligned}
& E_{M}=2 \cdot R M R-100 \\
& E_{M}=10^{(R M R-10) / 40}
\end{aligned}
$$

2.4.4. Classificações brasileiras utilizadas em barragens

\subsubsection{Metodologia do IPT}

A metodologia adotada pelo IPT, e que foi utilizada para os estudos da fundação da barragem de Ilha Solteria, é a que melhor se adaptou para as barragens no Brasil segundo Monticeli (1983). A classificação é estabelecida com base em estudos de testemunhos de sondagens ou sobre superfícies e paredes rochosas, e tem como finalidade estudar a estabilidade da fundação. Considera como parâmetros classificatórios o grau de alteração da rocha e o fraturamento, e através da conjunção destes dois parâmetros é obtida a classe do maciço rochoso. A realização de ensaios permite estabelecer parâmetros mecânicos quantitativos a cada uma das classes encontradas, como por exemplo, módulo de deformabilidade e parâmetros de cisalhamento. 


\subsubsection{Classificação geotécnica preliminar de Guidicini}

Guidicini et al (1972a), utilizando testemunhos de sondagem, taludes rochosos, ou galerias subterrâneas, propõe um método de caracterização geotécnica preliminar de maciços rochosos. Para tal, são utilizados a classificação genética sumária da rocha, o grau de alteração, o grau de resistência, o grau de coerência, o grau de fraturamento e o tipo de fraturamento, com os quatro primeiros parâmetros definindo a classe da rocha, que combinada com os dois últimos (grau e tipo de fraturamento) definem a classe do maciço.

\subsubsection{Modelo de compartimentação de Monticeli}

Segundo Monticeli (1983) a caracterização e a compartimentação geológico-geotécnica resultam das investigações de campo e dos ensaios de laboratório, que para o estudo de barragens devem ser os seguintes:

Investigações de superfície - corresponde à primeira etapa dos estudos, e são apresentados na forma de mapeamento geológico e geomorfológico. São feitos em três etapas: trabalhos prévios de escritório (pesquisa bibliográfica, interpretação de fotos aéreas e imagens de satélite, elaboração de mapas fotointerpretados, e formulação de um plano de levantamento de campo); trabalhos de campo (descrição detalhada de afloramentos, reconhecimento de estruturas, contatos litológicos e feições geomorfológicas, e coleta de amostras); e elaboração do relatório (análise e interpretação dos dados, elaboração de mapas e texto explicativo).

Investigações de subsuperfície - correspondem às sondagens mecânicas (trado, percussão e rotativa), poços de investigação e ensaios geofísicos, que devem ser locados topograficamente. 
Ensaios de laboratório - corresponde aos trabalhos de caracterização tecnológica e mecânica de amostras coletadas. Os resultados obtidos são analisados em conjunto com os demais trabalhos de investigação, e são correlacionados às unidades ou classes de maciço rochoso.

A caracterização geológico-geotécnica corresponde ao conjunto de informações obtidas através das investigações e dos ensaios tecnológicos e mecânicos. Monticeli (1983) sugere que as descrições geológicas sejam feitas separadas das descrições geotécnicas. As descrições geológicas devem conter o nome da rocha junto de uma breve descrição da litologia. As descrições geotécnicas são constituídas da recuperação por manobra, grau de alteração, grau de coerência, grau de fraturamento, índice de qualidade da rocha (IQR) ou $R Q D$, índice de resistência a penetração, ensaio de lavagem por tempo, condutividade hidráulica, e condições das descontinuidades.

Os ensaios de laboratório são divididos pelo autor em ensaios principais (resistência a compressão uniaxial, módulo de deformabilidade, coeficiente de Poisson, velocidade sônica, ensaios de desagregabilidade, índices físicos, e ensaios em solo), que podem ser realizados em poucas amostras e a custos baixos, e ensaios acessórios (lâminas petrográficas, compressão diametral, cisalhamento direto, fluência, etc..) recomendados para obras de grande porte ou de complexidade geológica.

A caracterização do maciço rochoso reúne detalhadamente todo o conjunto de informações geológico-geotécnicas de interesse do projeto. A interpretação e a síntese desse conjunto de informações permite a elaboração da compartimentação do maciço rochoso que será utilizada no projeto. Segundo Monticeli (1983) a compartimentação pode ser feita através de classes ou de unidades geológico-geotécnicas. A compartimentação através de classes de maciço é bastante subjetiva, e reflete normalmente condições mais conservadoras e tentativas de universalização de classificações. Na compartimentação em unidades 
geológico-geotécnicas estas dificuldades são superadas e o produto final retrata as necessidades do projeto.

\subsubsection{Casos de aplicação de sistemas de classificação em barragens}

São poucos os trabalhos publicados sobre a utilização de sistemas de classificação para estudos de barragens. No Brasil, o estudo de Dobereiner et al (1987) sobre a caracterização geomecânica do maciço rochoso de fundação da UHE Cachoeira Porteira, usa a classificação RMR em zonas pré-definidas com a finalidade de obter parâmetros geomecânicos, como coesão e módulo de deformabilidade, não sendo o sistema RMR a principal ferramenta na compartimentação do maciço. Da mesma forma, Carvalho et al (1987) sobre o estudo da compartimentação geomecânica da fundação da UHE de Babaquara, no Rio Xingu, o uso da classificação RMR tem apenas a finalidade de obter parâmetros de resistência para o maciço.

Figueiredo (1996) utilizou as classificações de Barton e Bieniawski, em galerias, para a caracterização geomecânica do maciço de fundação da UHE Tijuco Alto, na região do Vale da Ribeira entre os estados de São Paulo e Paraná. Para o autor os resultados obtidos foram compatíveis na caracterização do maciço. Além disso, comparando os módulos de deformação obtidos através de equações empíricas com os obtidos em ensaios in situ, a classificação de Barton, avaliou mais realisticamente o maciço estudado, principalmente devido a este sistema ser mais sensível no tocante às condições das descontinuidades.

Malafaia (2007) utilizou o sistema RMR e o SMR, Slope Mass Rating (Romana, 1993, apud Malafaia, op.cit), em um estudo comparativo para o maciço rochoso da UHE Batalha, constituído principalmente por filitos. Para o estudo, a classificação foi aplicada diretamente nos testemunhos de sondagem, nos quais foram determinados previamente trechos com características uniformes para o cálculo da nota do maciço. 
Mesquita (2008), no estudo realizado na AHE de Jirau, no Rio Madeira, realizou o estudo da compartimentação do maciço de fundação utilizando seis métodos de classificação, e considerou que o RMR é o que melhor se aplicava ao estudo devido os valores obtidos serem compatíveis com o esperado, e pela sua forma simples de aplicação.

Há uma grande quantidade de estudos recentes sobre a caracterização de maciços rochosos para barragens, utilizando o sistema RMR, no Oriente Médio, como a barragem de Wadi Mujib, na Jordania (El-Naqa, 1994), a barragem de Tabarak Abad no Iran (Lashkaripour e Ghafoori, 2002), e as barragens de Urus (Özsan e Akin, 2002) e Obruk (Kocbay e Kilic, 2006) na Turquia. Nestes estudos, a classificação geomecânica é utilizada geralmente em conjunto com outros métodos, como o sistema Q ou o RQD, com o objetivo de estimar parâmetros geomecânicos do maciço. A classificação é aplicada no maciço rochoso como um todo, ou quando há mais de uma litologia, para cada tipo litológico, considerando-se sempre a pior condição do maciço. 


\section{MÉTODO}

O desenvolvimento deste estudo pode ser dividido em quatro etapas: planejamento, coleta de dados, aplicação e análise dos resultados, sendo que o seqüenciamento de cada etapa é ilustrado no fluxograma da Figura 4.

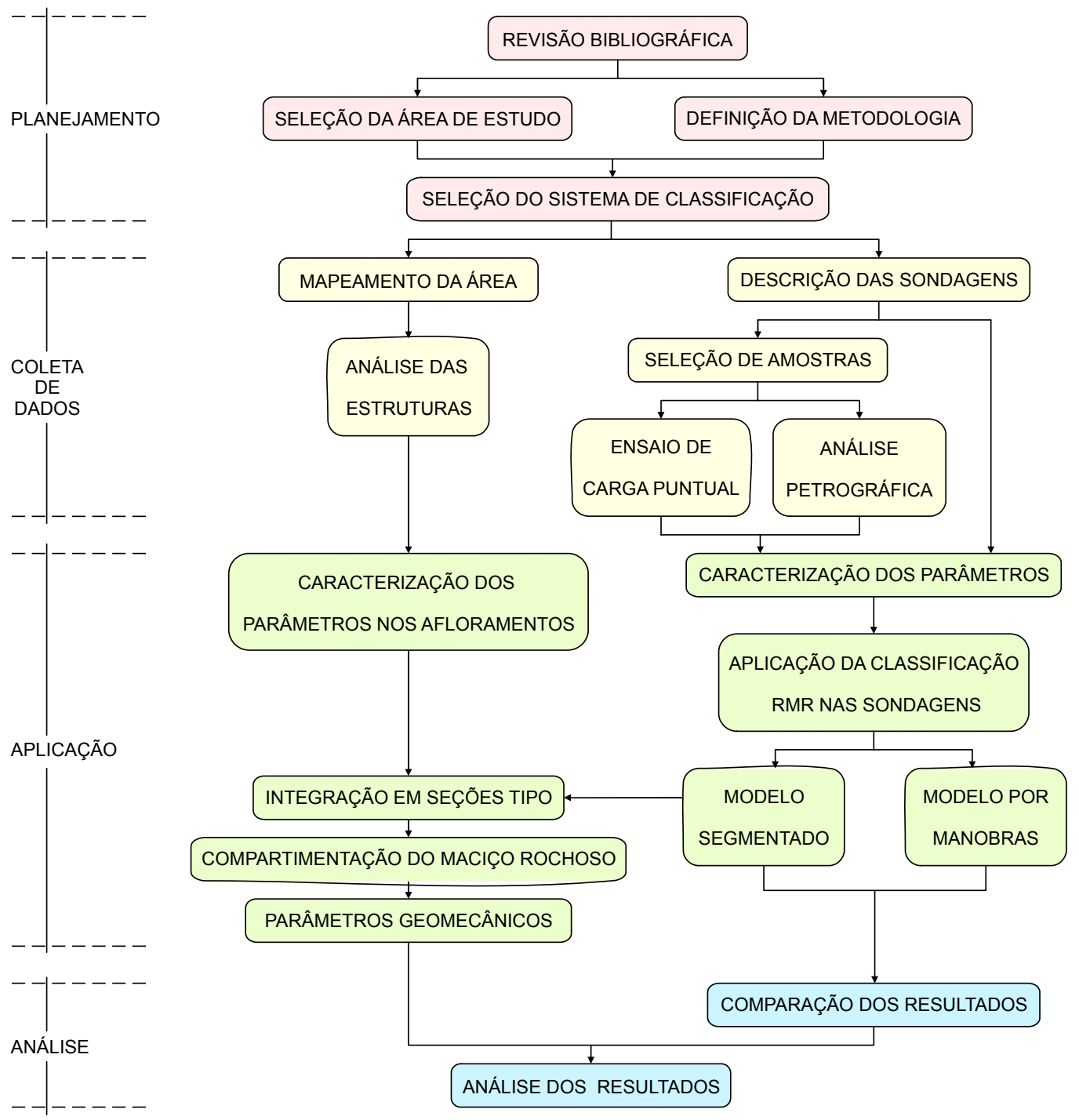

Figura 4 - Fluxograma das atividades desenvolvidas. 


\subsection{Planejamento}

Este estudo iniciou-se com uma revisão da bibliografia existente sobre as PCH's, sobre as metodologias de classificação de maciços rochosos, e sobre a aplicação de sistemas de classificação em barragens. A seleção da área para o estudo foi baseada em critérios como: a existência de sondagens rotativas, a possibilidade de acesso aos testemunhos de sondagem, e o consentimento de uso dessas informações.

\subsubsection{Definição da metodologia e seleção do sistema de classificação}

A definição da metodologia para a compartimentação do maciço rochoso foi baseada nas informações obtidas na bibliografia estudada e no tipo de dados que estariam disponíveis na área de estudo, que são: superficiais - obtidos pelo mapeamento da área; sub-superficiais obtidos das sondagens rotativas; e dados de ensaios - possibilidade de realização de ensaios de baixo custo. Optou-se pela escolha de um sistema de classificação que permitisse a aplicação direta nas sondagens, de forma linear, onde as classes determinadas pelo sistema definiriam os compartimentos, e a compartimentação final pudesse ser representada de forma bi-dimensional em seções, obtidas pela interpolação da classificação feita nas sondagens, com o apoio das informações do mapeamento de campo.

Das metodologias de classificação estudadas, as que melhor se adequaram aos objetivos propostos foram os sistemas RMR e Q. O sistema RMR apresentou vantagens em relação ao sistema $\mathrm{Q}$ por poder ser aplicado aos diversos tipos de estruturas existentes na $\mathrm{PCH}$, enquanto o sistema $Q$ é mais voltado para túneis. Outros fatores que favorecem o sistema RMR são a grande disseminação desta classificação nas obras civis, sendo freqüentemente utilizado por outros autores, a maior facilidade de aplicação do sistema, além de fornecer estimativas de parâmetros geomecânicos para o maciço. 


\subsection{Coleta de dados}

\subsubsection{Mapeamento da área}

Um estudo preliminar da área foi feito com o apoio de fotos aéreas na escala 1:60.000, de 1964. Pela análise estereoscópica das fotos aéreas foram reconhecidas as principais feições estruturais, como lineamentos e quebras de relevo. O mapeamento de campo foi feito sobre a planta base da área, que apresenta um levantamento topográfico detalhado da área das estruturas. O estudo procurou mapear os afloramentos rochosos na área das estruturas, descrevendo a litologia, grau de alteração e famílias de fraturas. As fraturas foram descritas quanto a sua orientação, espaçamento, abertura, preenchimento e persistência. As direções das fraturas foram representadas em diagrama de rosetas, com o auxílio do programa EstereoNett, e plotadas no mapa base da área.

\subsubsection{Descrição das sondagens}

Foi feita a descrição dos testemunhos de sondagem em boletins, informando o tipo litológico, a presença de estruturas e a recuperação por manobra. A caracterização do grau de alteração foi baseada na proposta do IPT, conforme a Tabela 2 (página 6). Os segmentos de rocha foram medidos para os cálculos de RQD e IQR. Foram identificadas as fraturas causadas pelo processo de perfuração. As fraturas foram descritas quanto ao mergulho (horizontal, vertical ou inclinada) e plotadas nos boletins de sondagem com seu espaçamento real. O espaçamento das fraturas foi calculado como o espaçamento médio das fraturas em zonas de fraturamento homogêneos. As fraturas também foram descritas quanto a alteração, preenchimento e rugosidade, conforme a proposta de Bieniawski (1989) apresentada na Tabela 19 (página 30), sendo todas essas informações indicadas no boletim de sondagem. 


\subsubsection{Análise petrográfica}

Foi feita a seleção de uma amostra representativa do maciço para análise petrológica através de lâmina delgada, no Laboratório de Análises de Minerais e Rochas - Lamir - do Departamento de Geologia da UFPR.

\subsubsection{Ensaio de carga puntual}

Foram selecionadas amostras representativas dos diferentes graus de alteração, para determinação da resistência da rocha através do ensaio de compressão puntual, que foi escolhido por ser um ensaio simples e de baixo custo. Com base nas recomendações da ISRM (1985) se optou pelo ensaio diametral, por ser o que envolve cálculos mais simples para o formato das amostras. O número de amostras selecionadas respeitou o número mínimo de 10, sugerido pela ISRM. A seleção das amostras procurou ter uma distribuição homogênea ao longo das sondagens. O ensaio foi realizado no equipamento de compressão puntual do Laboratório de Mecânica das Rochas do Departamento de Geotecnia da Escola de Engenharia de São Carlos (Figura 5), de acordo com as especificações sugeridas pela ISRM (1985).

Durante o ensaio foram medidos o diâmetro e o comprimento das amostras (Figura 6), e a pressão registrada no manômetro $(p)$, em $\mathrm{Kgf} / \mathrm{cm}^{2}$, no momento da ruptura da amostra. Para determinar resistência, a pressão lida no manômetro foi transformada em força através da equação 15 , obtida pela calibração do equipamento, sendo $Q$ a carga puntual em KN, e $p$ a pressão lida no manômetro em $\mathrm{Kgf} / \mathrm{cm}^{2}$.

$$
Q=[(0,328 \times p)-0,2158]
$$

Para calcular o índice de carga puntual $\left(I_{s}\right)$ é utilizada a equação 1 (página 11), que relaciona a carga aplicada $(Q)$, e o diâmetro equivalente $\left(D_{e}\right)$. O valor obtido deve ser multiplicado por 1000 para se obter o $I_{s}$ em MPa. Para o ensaio diametral o diâmetro 
equivalente $D_{e}$ é igual ao diâmetro da amostra (equação 2). A correção do índice de carga puntual $\left(I_{s}\right)$ para o diâmetro de $50 \mathrm{~mm}\left(I_{s(50)}\right)$ é feito através do cálculo do fator de correção $F$, da equação 6 , sendo o $I_{s(50)}$ calculado pela equação 5 .
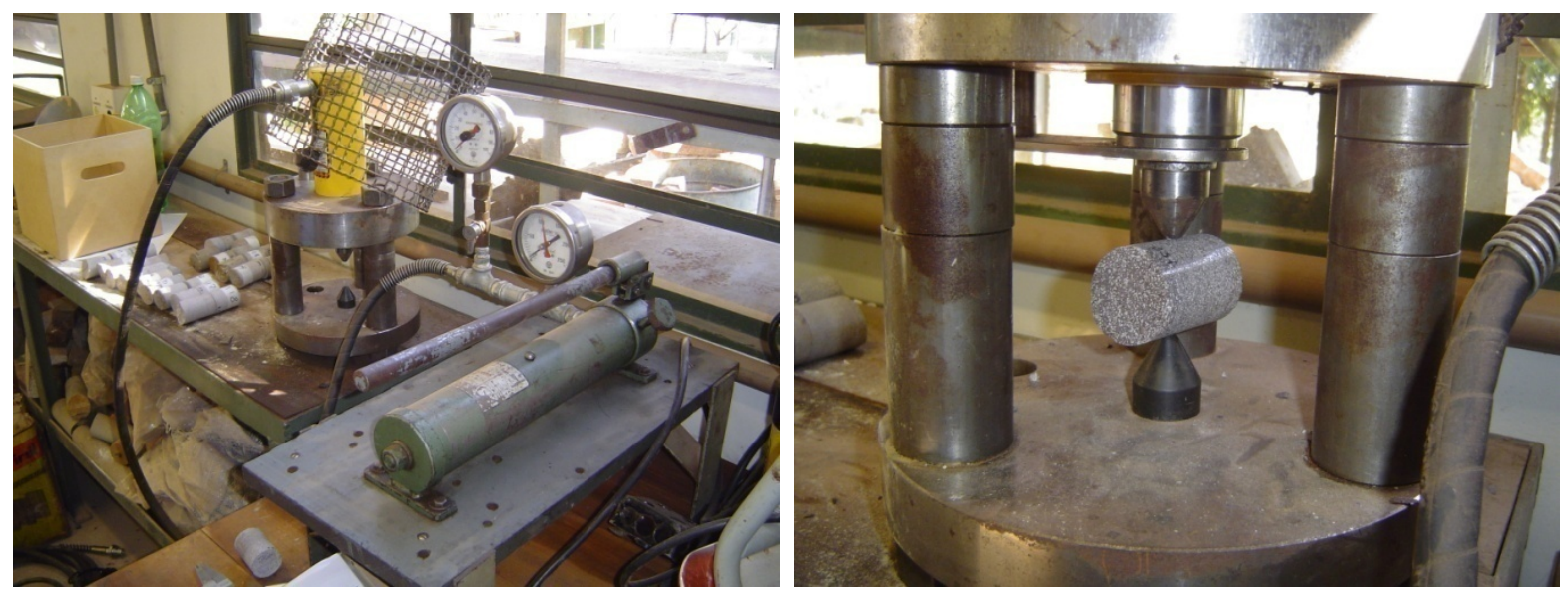

Figura 5 - Equipamento de compressão puntual, e posicionamento da amostra para o ensaio.
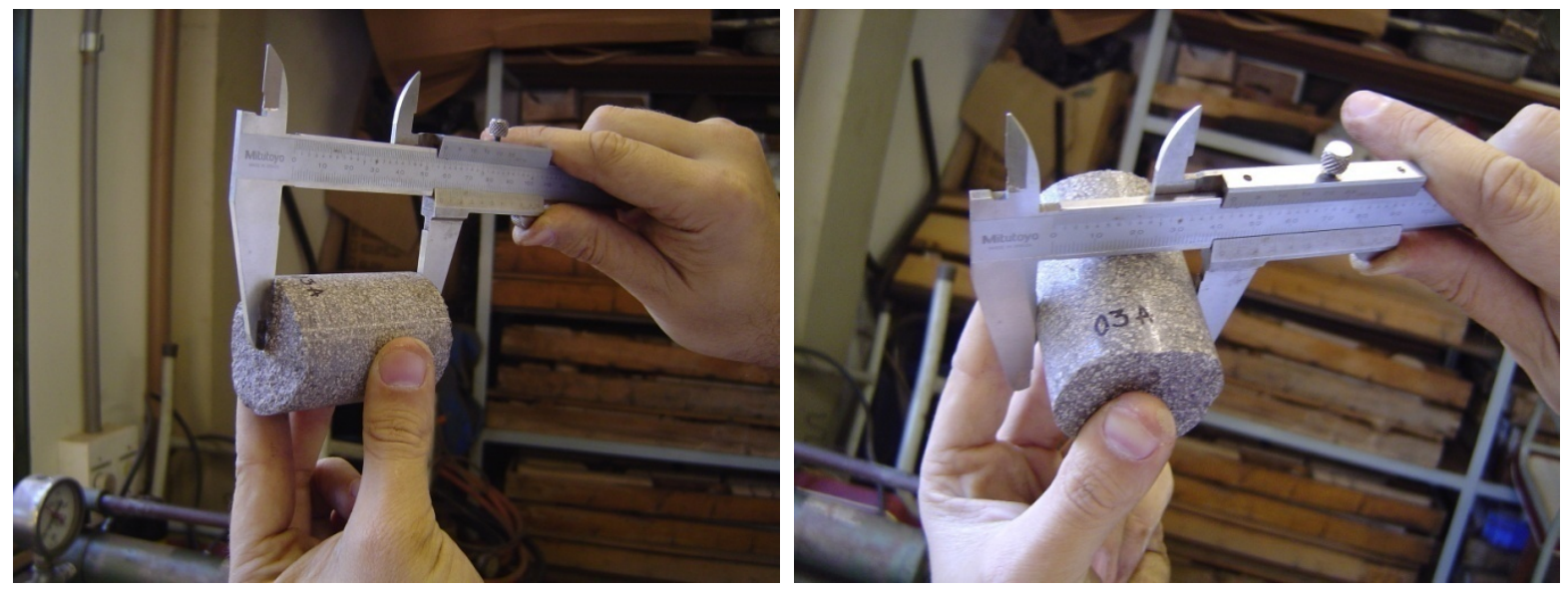

Figura 6 - Aferição das dimensões da amostra, largura e diâmetro.

\subsection{Aplicação}

O sistema RMR foi o sistema de classificação escolhido para a realização do estudo. Como o maciço rochoso da área em estudo se apresenta muito uniforme, optou-se por aplicar o sistema RMR de forma direta nos testemunhos de sondagem, e de forma parcial nos afloramentos, sem a pré-divisão de regiões estruturais para aplicação da classificação. 
Algumas modificações foram feitas ao sistema classificação, com a intenção de deixá-lo mais sensível às variações dos parâmetros considerados. A primeira delas consiste em aplicar a classificação diretamente no boletim de descrição da sondagem, o qual foi modificado para incluir campos para a descrição dos parâmetros, e para a representação final da classificação. A segunda modificação foi não pré-compartimentar a sondagem em zonas homogêneas para aplicar a classificação, e deixar que a variação dos parâmetros determine a segmentação da sondagem. No final os segmentos com mesma classificação são agrupados, definindo um compartimento. A terceira modificação proposta foi vincular a resistência da rocha intacta ao grau de alteração, permitindo que ao longo da sondagem sejam identificadas as variações de resistência pela determinação do grau de alteração. A quarta modificação foi substituir o RQD pelo IQR.

\subsubsection{Caracterização dos parâmetros nas sondagens}

Para a aplicação do sistema RMR nas sondagens, cada um dos seis parâmetros considerados foram caracterizados e representados ao longo das sondagens nos boletins de descrição.

- O valor da resistência da rocha foi determinado para os diferentes graus de alteração da rocha, e foi obtido através dos ensaios de carga puntual.

- O valor do IQR foi obtido pela soma dos pedaços de testemunho maiores que $10 \mathrm{~cm}$, divididos pelo comprimento total do trecho considerado, em percentagem. O diâmetro das sondagens é o BW, menor que o recomendado para o cálculo do RQD, o NW.

- O espaçamento das descontinuidades foi determinado através do cálculo do espaçamento médio das fraturas em zonas de espaçamento homogêneo.

- A condição das fraturas, que pode ser subdividida em persistência, abertura, rugosidade, preenchimento e alteração, foi caracterizada com base na descrição detalhada dos testemunhos, e determinou zonas de mesmas características ao longo das sondagens. 
- A ação da água subterrânea foi determinada através da relação entre a pressão de água e a tensão principal, ao longo da sondagem. Para os cálculos foram convencionados os seguintes valores de massa específica: água $=1 \mathrm{~g} / \mathrm{cm}^{3}$; solo $=1,8 \mathrm{~g} / \mathrm{cm}^{3}$; rocha $=$ $2,7 \mathrm{~g} / \mathrm{cm}^{3}$.

- O ajuste para orientação de descontinuidades foi determinado segundo a análise da influência das descontinuidades na estrutura encontrada na área de cada sondagem.

Determinados todos os parâmetros e os seus respectivos pesos relativos, foi feito o somatório final dos pesos de cada parâmetro, obtendo-se assim a nota final, para cada segmento, que foi representada no boletim de sondagem.

Para verificar se as modificações propostas melhoram o resultado final da compartimentação, a classificação também foi aplicada da forma convencional, denominada de 'classificação por manobras', permitindo a comparação entre os dois resultados.

\subsubsection{Classificação dos afloramentos}

A aplicação do sistema RMR nos afloramentos de campo foi parcial, e se ateve à atribuição de pesos relativos aos parâmetros descritos em campo, sendo eles: espaçamento, persistência, abertura, preenchimento e orientação das descontinuidades.

\subsubsection{Integração em seções tipo}

Foram elaboradas duas seções tipo ao longo dos eixos das principais estruturas previstas no projeto, buscando-se integrar e espacializar os resultados obtidos na aplicação do sistema RMR nos furos de sondagem e nos levantamentos de campo. Nestas seções foram lançados os resultados da aplicação do sistema RMR nas sondagens rotativas, e os pontos de campo. As sondagens e os pontos de campo foram relacionados de acordo com a proximidade entre si. Os pesos relativos dos parâmetros classificados nas sondagens foram 
confrontados com os pesos atribuídos para os parâmetros classificados nos afloramentos, sendo considerado o peso de valor mais baixo para o cálculo da nota final.

Relacionadas as informações das sondagens e dos afloramentos, e determinadas a variações das classes no interior do maciço rochoso, foi possível esboçar a compartimentação do maciço. O traçado dos compartimentos buscou a interpolação da classificação obtida nas sondagens, e utilizou as informações resultantes do cruzamento da classificação das sondagens com os pontos de campo para auxiliar na determinação da continuidade, ou não, dos compartimentos no interior do maciço.

\subsubsection{Estimativa de parâmetros geomecânicos}

Para cada classe de maciço, a classificação RMR atribui uma estimativa de tempo médio de auto-sustentação e vão livre de seção para túneis, além de valores de coesão e ângulo de atrito (ver Tabela 21, página 30). As equações 9 a 12 (página 31) permitem que se calculem estes parâmetros através da nota RMR encontrada, enquanto as equações 13 e 14 (página 32) permitem que se calcule o módulo de deformabilidade. Com base nestas equações foram calculados os parâmetros geomecânicos para os compartimentos encontrados nas seções.

\subsection{Análise}

A análise dos resultados avaliou os ganhos obtidos com as modificações propostas, comparando as duas formas de classificação das sondagens, e a metodologia utilizada para se obter a compartimentação do maciço. 


\section{CARACTERIZAÇÃO DA ÁREA DE ESTUDO}

\subsection{Localização}

A PCH Morro Grande foi o local escolhido para a aplicação do estudo, e fica localizado na porção nordeste do Estado do Rio Grande do Sul (Figura 7), no município de Muitos Capões, a sudeste da localidade de Ituim, entre as coordenadas 6839500/6841000N e 469250/470250E do sistema de projeção UTM, datum SAD-69. Localiza-se no Rio Ituim, afluente da margem esquerda do Rio Turvo, que por sua vez é afluente da margem direita do Rio das Antas, pertencente ao sistema de drenagem do Rio Jacuí, que drena suas águas para a Lagoa dos Patos.

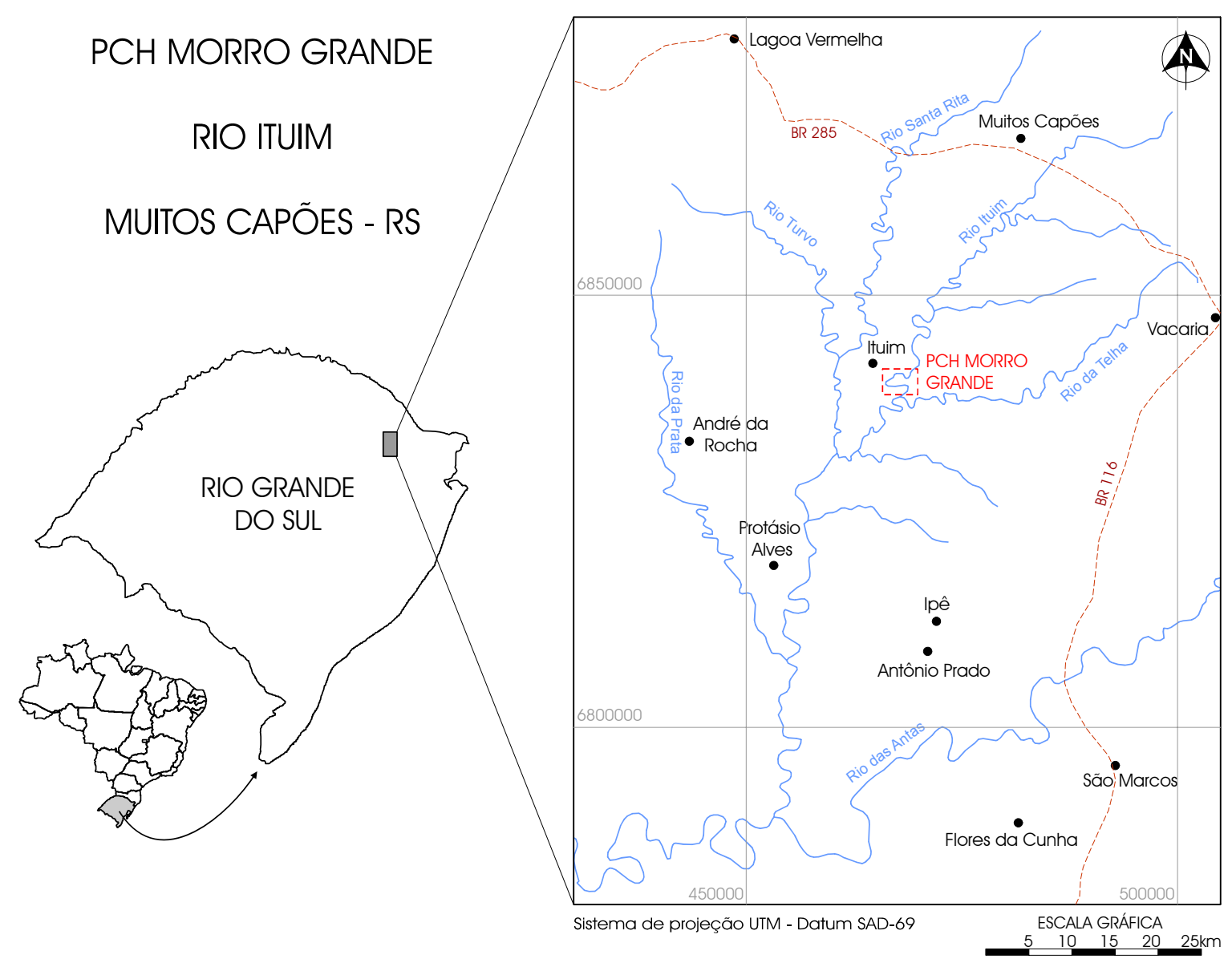

Figura 7 - Figura esquemática coma a localização da área de estudo. 
$\mathrm{Na}$ área estão disponíveis os dados de quatro sondagens rotativas, a planta da $\mathrm{PCH}$ com a localização das sondagens e demais estruturas, fotografias aéreas de escala 1:60.000, e os detalhes construtivos da obra, que foram gentilmente fornecidos pela Design Head Engenharia e Construtora e pela Hidrelétrica Morro Grande Ltda.

\subsection{Caracterização da PCH}

A Figura 8 mostra a área de estudo com a localização das estruturas da PCH Morro Grande, dos pontos das sondagens rotativas, e dos pontos de levantamento de campo.

$\mathrm{O}$ arranjo da $\mathrm{PCH}$ Morro Grande prevê um barramento misto, composto por um vertedor central em concreto na cota $640 \mathrm{~m}$ com comprimento total de 150 metros e altura máxima de 6 metros, apoiado em contrafortes, e um dique de enrocamento com núcleo de argila sobre a ombreira esquerda, com topo na cota $644 \mathrm{~m}$, com extensão total de 107 metros, e altura máxima de 10 metros. O bloco de desvio será incorporado ao eixo da barragem, posicionado na margem esquerda justaposto ao muro de contenção do dique. No local existe uma sondagem - SR1, na margem esquerda, com 12 metros de profundidade.

O circuito hidráulico se inicia em uma tomada d'água incorporada ao dique da barragem. 0 canal de adução foi projetado encaixado na rocha. Sua seção é retangular com 6 metros de base por 3 metros de altura, com extensão total de 410 metros.

O túnel de adução será escavado em rocha, sem revestimento, em seção arco-retângulo com diâmetro 4,5 metros e uma extensão hidráulica total de 660 metros. O túnel trabalha afogado à baixa pressão e foi projetado para uma velocidade máxima de $1,05 \mathrm{~m} / \mathrm{s}$. No local existem duas sondagens, uma no emboque - SR2, com 40 metros de comprimento, e outra no desemboque - SR3, com 23 metros de comprimento. 


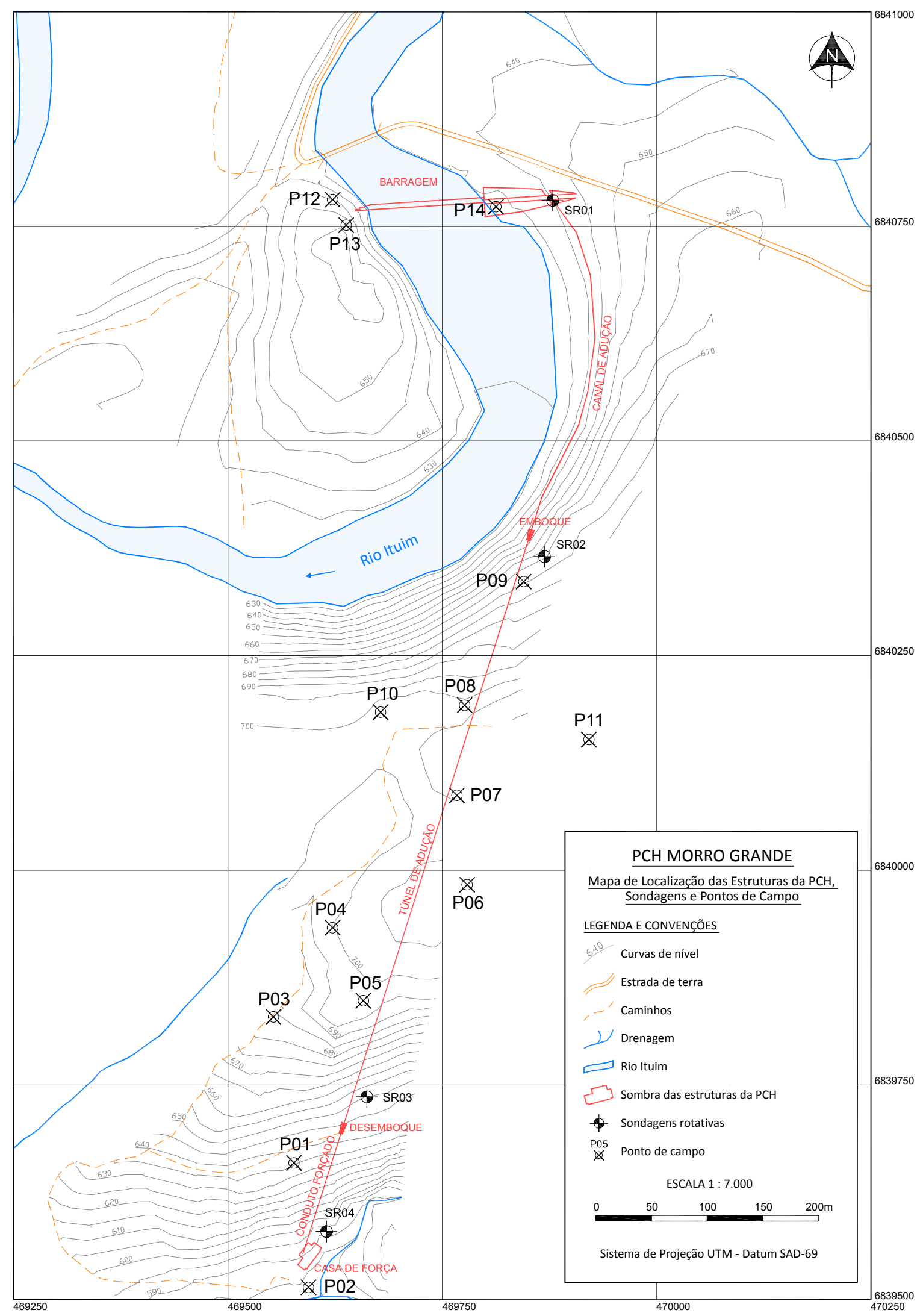

Figura 8 - Layout das estruturas da PCH Morro Grande. 
Após o desemboque o fluxo segue por um canal de 52 metros de extensão escavado em rocha até a estrutura da câmara de carga. Este canal tem uma seção retangular com 6 metros de base por 5 metros de profundidade. Da câmara de carga segue em uma linha de conduto forçado com comprimento total de 146 metros, que se bifurca ao final para atender as duas unidades geradoras.

Após a passagem pela casa de máquinas a água é restituída ao rio através de um canal de fuga longo, que se desenvolve parcialmente dentro da própria calha do rio. No local da casa de força há outra sondagem - SR4, com 23 metros de comprimento.

\subsection{Geologia regional da área}

A área de estudo está inserida no contexto geológico da Bacia do Paraná, mais precisamente sobre os extensos derrames basálticos da Formação Serra Geral, na região serrana do Rio Grande do Sul.

\subsubsection{Bacia do Paraná}

A bacia intracratônica do Paraná ocupa uma área de aproximadamente $1.500 .000 \mathrm{~km}^{2}$ no Brasil, e ocupa ainda parte da Argentina, Paraguai e Uruguai. A sua dimensão norte-sul atinge quase 2000 km no território nacional, apresentado uma orientação NNW no seu eixo principal. Abrange parte dos estados de São Paulo, Mato Grosso do Sul, Goiás, Mato Grosso, Minas Gerais, Paraná, Santa Catarina e Rio Grande do Sul. Possui inclinação homoclinal em direção ao oeste, porção mais deprimida (Schobbenhaus et al. 1984, Milani et al. 1994). 
É uma bacia sedimentar intracratônica, ou sinéclise, que evoluiu sobre a Plataforma SulAmericana. Sua formação teve início a cerca de 450 milhões de anos, no final do Período Ordoviciano, e termina no Cretáceo. A estratigrafia mais utilizada atualmente para a Bacia do Paraná é a proposta na revisão de Milani et al. (1994) com base no trabalho clássico de Schneider et al. (1974). Milani et al. $(1994,1998)$ dividiram o registro estratigráfico da Bacia do Paraná em seis superseqüências limitadas por discordâncias regionais, sendo elas: a Superseqüência Rio Ivaí de idade Ordovício-Siluriana; a Superseqüência Paraná correspondente às Formações de idade Devoniana; a Superseqüência Gondwana I, do NeoCarbonífero ao Eo-Triássico; a Superseqüência Gondwana II correspondente às Formações Pirambóia e Rosário do Sul; a Superseqüência Gondwana III que corresponde ao Grupo São Bento, e por fim a Superseqüência Bauru do Neo-Cretáceo, onde novas condições de sedimentação continental foram instaladas na Bacia do Paraná, com a deposição dos Grupos Bauru e Caiuá (Figura 9).

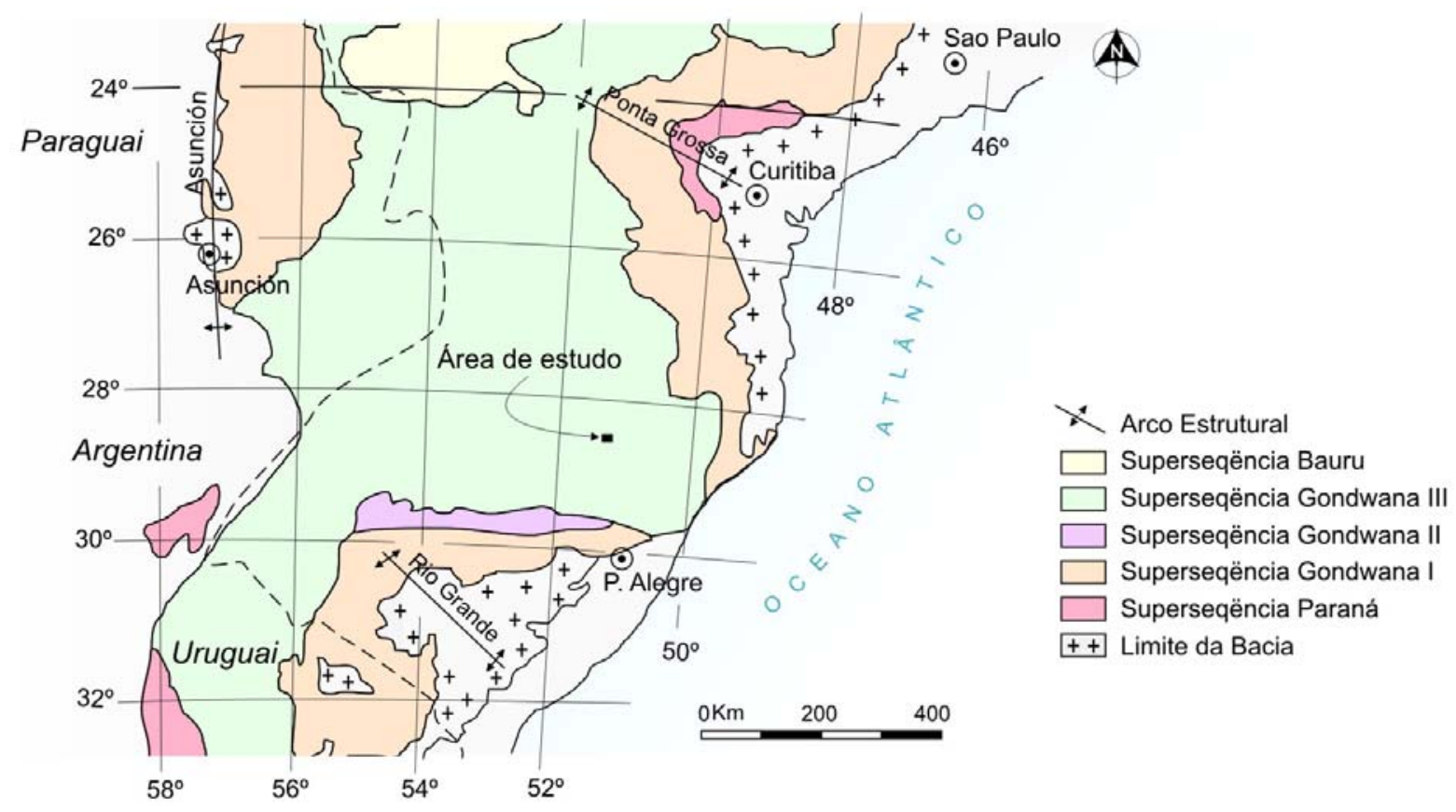

Figura 9 - Mapa geológico simplificado da Bacia do Paraná (modificado de Milani, 1998). 
Estas superseqüências correspondem a diferentes ciclos de subsidência da bacia, que são reflexos intracratônico de eventos orogênicos ocorridos na borda da placa. Neste contexto observa-se que a Formação Serra Geral é resultado dos esforços extencionais relacionados à separação do Gondwana, ou seja, da separação entre a América do Sul e a África.

\subsubsection{Formação Serra Geral}

A Formação Serra Geral compreende um extenso conjunto de derrames de rochas ígneas de idade Eo-Cretácea, predominantemente basaltos. Os basaltos são rochas de composição básica (teor de sílica entre 45 e 52\%) que, nas variedades maciças, apresentam coloração cinza escura a preta. Nas variedades afaníticas, certa porção é constituída de matéria vítrea, enquanto nas variedades de granulação mais grossa, os minerais formam cristais milimétricos visíveis a olho nu (Leinz, 1949).

Estas rochas ocorrem na forma de derrames tabulares cujas espessuras podem variar de metros a dezenas de metros. Cada derrame é formado de uma seqüência de litologias distintas. Esta seqüência é constituída por brecha vulcânica e vidro vulcânico na parte inferior, basaltos maciços no meio do derrame, e por basalto vesículo-amigdalóide e brechas basálticas no terço superior. O diaclasamento é horizontal na parte inferior e superior do derrame, e vertical na parte central. Os basaltos vesiculares e amidalóides, que têm presença constante no topo dos derrames, são rochas avermelhadas ou acinzentadas, cheias de vesículas formadas pelo escapamento dos gases durante o resfriamento das lavas. As vesículas podem variar no diâmetro, de milímetros a centímetros, apresentando preenchimentos parciais ou totais de ágata, quartzo, zeólitas, calcita e celadonita (Souza Júnior, 1986).

Intercalados aos derrames básicos ocorrem pacotes ácidos. Estas rochas são interpretadas como diferenciações do magma original ou modificações do mesmo, por assimilação de 
materiais mais superficiais. Constituídas principalmente por riolitos e riodacitos, que de forma geral apresentam as mesmas características que suas correspondentes básicas, sendo a principal diferença a constituição mineralógica (Marimon et al, 1982).

\subsubsection{Aspectos estruturais}

Os lineamentos do arcabouço estrutural na área de estudo, assim como no restante da Bacia do Paraná, podem ser reunidos em duas direções principais: NE-SW e NW-SE. Nos lineamentos visíveis na Bacia do Paraná pode-se observar um marcante padrão de feições lineares em forma de $\mathrm{X}$, podendo ser divididas em três grupos de acordo com suas orientações (NW-SE, NE-SW e E-W). As duas mais importantes são as orientações NW-SE e NE-SW, as quais constituem zonas de fraqueza antigas que foram reativadas durante a evolução da bacia (Zalán et al. 1987).

Segundo Zalán et al. (1987), as falhas de direção NE-SW são geralmente constituídas por uma única falha larga ou uma zona de falha retilínea, com freqüentes evidências de movimentações transcorrentes. Já os diversos lineamentos de direção NW-SE estão normalmente preenchidos por diques de diabásio dos arqueamentos estruturais relacionados ao vulcanismo fissural continental da Bacia do Paraná. As formações pertencentes ao Grupo São Bento têm densidade baixa de fraturamento, não apresentando um padrão definido. As fraturas têm pequenas aberturas apresentando descoloração devido à lixiviação. São geralmente de persistência e regularidade variáveis.

A área de estudo encontra-se próximo à Falha de Leão e da Zona de Falha de Blumenau/Soledade, ambas de direção NE. A Sinclinal de Torres constitui um baixo estrutural na área, apresentando direção preferencial NW, e a área também se encontra próxima ao lineamento de Bento Gonçalves que apresenta direção geral E-W (Figura 10). Estas estruturas comumente formam linhas de fraqueza e controlam as direções 
preferenciais das drenagens. Nos basaltos desenvolve-se, geralmente, uma zona bastante densa de fraturas devida ao fraturamento conjugado, o qual forma duas famílias de juntas, oblíquas entre si nas vizinhanças dessa faixa cataclástica.

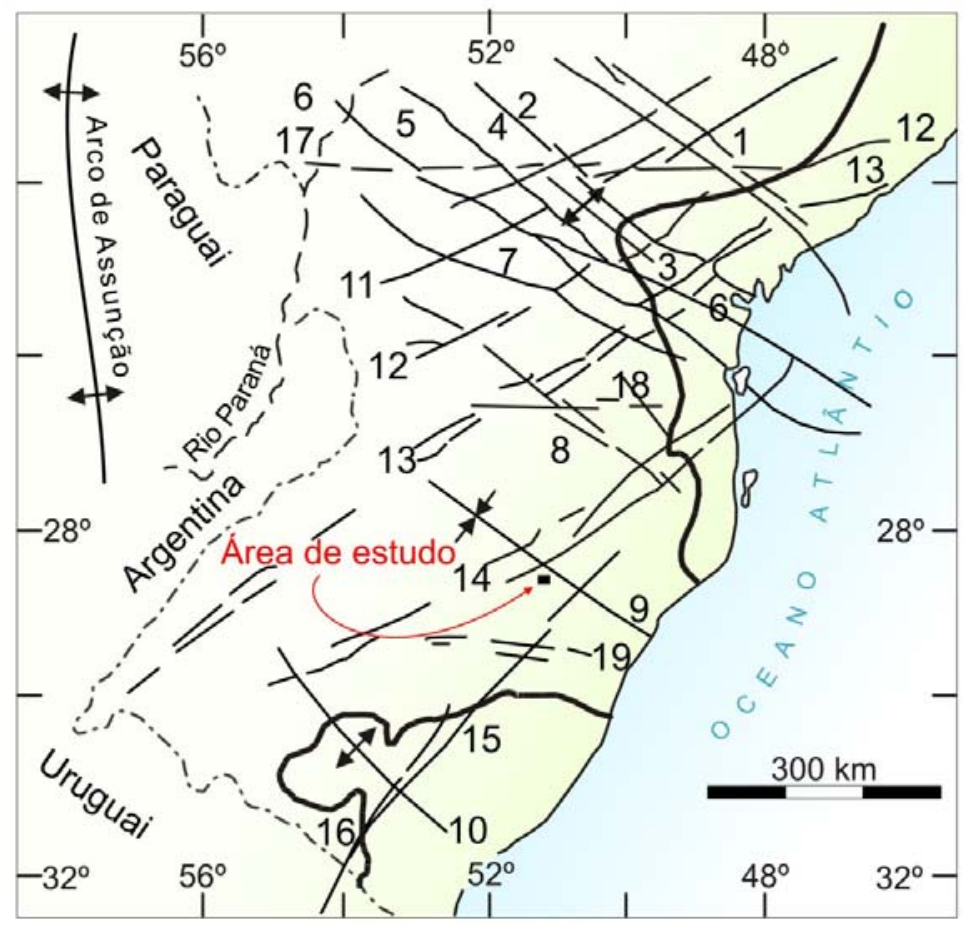

(1) ZF de Guapiara;

(2) Falha de São Jeronimo/Curiúva;

(3) Arco de Ponta Grossa;

(4) ZF Curitiba/Maringá;

(5) Falha do Rio Alonzo;

(6) ZF Candido de Abreu/CampoMourão;

(7) Lineamento do Rio Piquiri;

(8) ZF Caçador;

(9) Sinclinal de Torres;

(10) Arco do Rio Grande;

(11) Falha de Jacutinga;

(12) ZF de Taxaquara;

(13) ZF Lancinha/Cubatão;

(14) ZF de Blumenau/Soledade;

(15) Falha de Leăo;

(16) Falha de Açotea;

(17) Lineamento de São Sebastião;

(18) Lineamento de Taquara Verde;

(19) Lineamento de Bento Gonçalves.

Figura 10 - Arcabouço Estrutural da Bacia do Paraná. (modificado Zalán et al. 1987). 


\section{COLETA E ANÁLISE DOS DADOS}

\subsection{Mapeamento da área de estudo}

O local compreende uma área de cerca de $1500 \mathrm{~m}$ de comprimento, por $500 \mathrm{~m}$ de largura. Foram levantados ao todo quatorze pontos de campo, sendo a grande maioria afloramentos em chão. O mergulho das fraturas medidas nos afloramentos foi predominantemente subvertical, em menor proporção sub-horizontal, e raramente inclinado.

\section{Ponto 01}

Afloramento em chão, próximo ao desemboque do túnel. Encontrado litotipo basáltico com grau de alteração A2. Foram realizadas 17 medidas de fraturas no afloramento. Apresenta duas famílias principais, a família 1 de direção N10W-10E/90 e a família 2 de direção N4050E/90, e fraturas subordinadas de direções N25E/90 e N80W/90. Ocorre também um fraturamento sub-horizontal de direção NS/05E (Figura 11). O espaçamento médio das fraturas da família 1 e 2 é de um metro, com persistência menor que 5 metros. As fraturas encontram-se fechadas e sem preenchimento.

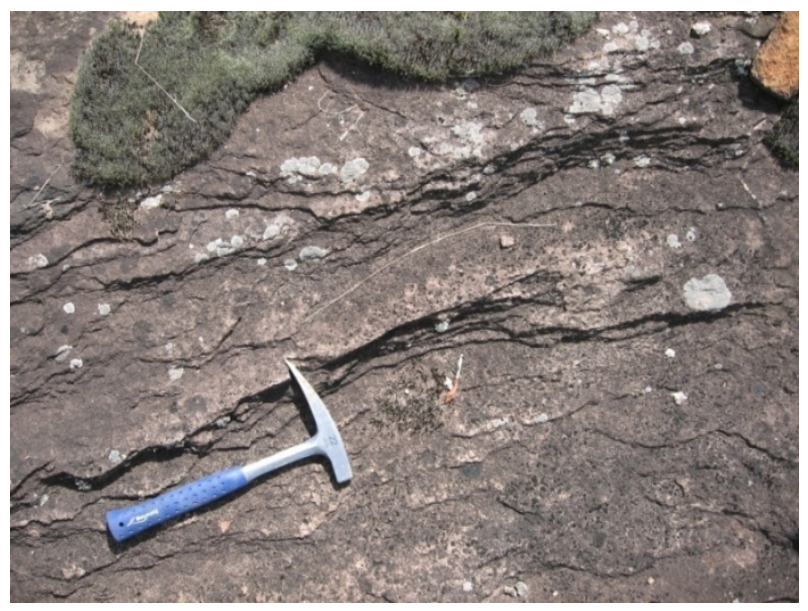

Figura 11 - Afloramento do ponto 01 , detalhe para o fraturamento sub-horizontal. 


\section{Ponto 02}

Afloramento em chão no leito do córrego, próximo à casa de força. Encontrado litotipo basáltico com grau de alteração A3. Foram realizadas 14 medidas de fraturas no afloramento. Apresenta uma família de fraturas principal de direção N50-70E/90 e fraturas subordinadas de direção N25E/90, NS/90 e N45W/90. O espaçamento médio das fraturas da família 1 é de meio a um metro, com persistência menor que 5 metros. As fraturas encontram-se fechadas e sem preenchimento.

\section{Ponto 03}

Afloramento em chão, próximo ao túnel. Encontrado litotipo basáltico com grau de alteração A2. Foram realizadas 7 medidas de fraturas no afloramento. Apresenta duas famílias principais, a família 1 de direção N80E/90 e a família 2 de direção N20-30W/90, e fraturas subordinadas de direções N60E/90 e N50W/90. No local há ocorrência de minerais magnéticos. O espaçamento médio das fraturas da família 1 é de meio a um metro, com persistência menor que 5 metros. As fraturas encontram-se fechadas e sem preenchimento, por vezes curviplanas.

\section{Ponto 04}

Afloramento em chão, próximo ao túnel. Encontrado litotipo basáltico com grau de alteração A2. Foram realizadas 28 medidas de fraturas no afloramento. Apresenta duas famílias principais, a família 1 de direção N50-70E/90, e a família 2 de direção N20W/90, e fraturas subordinadas de direção N80W/90 e N20-40E/90. Ocorre também uma fratura inclinada de direção N60E/45NW. No local há ocorrência de minerais magnéticos. O espaçamento médio das fraturas da família 1 é de meio a um metro, com persistência menor que 5 metros. As fraturas encontram-se fechadas e sem preenchimento, exceto por uma fratura de direção N70E/90 com abertura de $5 \mathrm{~mm}$ preenchida por material argiloso de coloração clara. 


\section{Ponto 05}

Afloramento em chão, próximo ao túnel (Figura 12). Encontrado litotipo basáltico com grau de alteração A2. Foram realizadas 10 medidas de fraturas no afloramento. Apresenta uma família principal de direção N80W/90, e fraturas subordinadas de direção N50-60W/90 e N05-20E/90. O espaçamento médio das fraturas da família 1 é de meio a um metro, com persistência menor que 5 metros. As fraturas encontram-se fechadas e sem preenchimento.

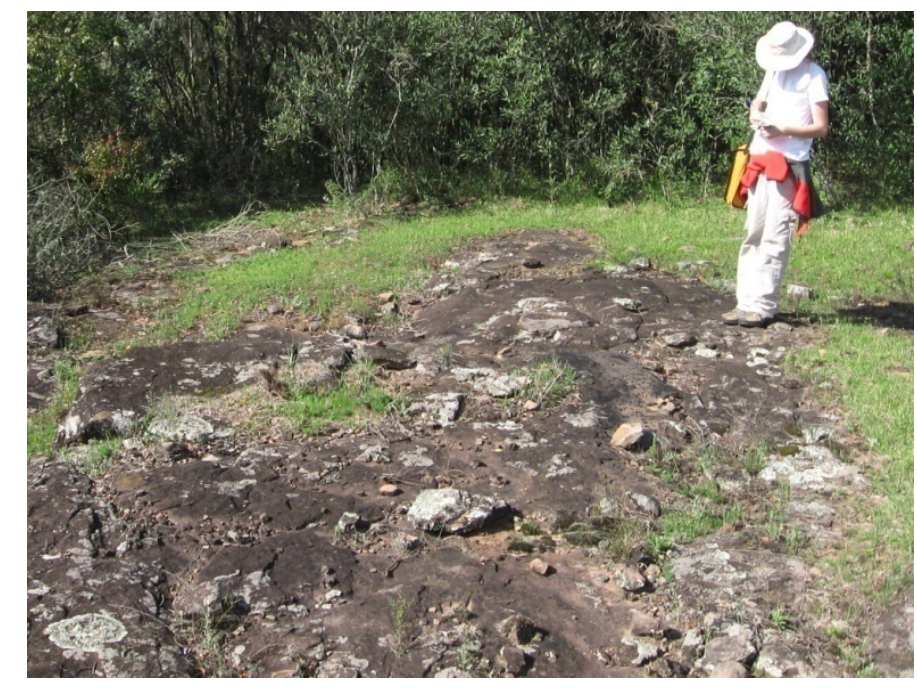

Figura 12 - Afloramento do ponto 05.

\section{Ponto 06}

Afloramento em chão, próximo ao túnel. Encontrado litotipo basáltico com grau de alteração A2. Foram realizadas 7 medidas de fraturas no afloramento. Apresenta uma família principal de direção N30-40E/90, e fraturas subordinadas de direção N80W/90 e N20W/90. O espaçamento médio das fraturas da família 1 é de meio a um metro, com persistência menor que 5 metros. As fraturas encontram-se fechadas e sem preenchimento, exceto por uma fratura de direção EW/90 que apresentou uma abertura de $5 \mathrm{~mm}$ preenchida por material argiloso de coloração avermelhada. 


\section{Ponto 07}

Afloramento em chão, próximo ao túnel. Encontrado litotipo basáltico com grau de alteração A2. Foram realizadas 18 medidas de fraturas no afloramento. Apresenta duas famílias principais, a família 1 de direção N60-80W/90, e a família 2 de direção N50E/90. Ocorre também uma fratura inclinada de direção N70W/60NE. O espaçamento médio das fraturas da família 1 é de meio a um metro, com persistência menor que 5 metros. As fraturas encontram-se fechadas e sem preenchimento.

\section{Ponto 08}

Afloramento em chão, próximo ao túnel. Encontrado litotipo basáltico com grau de alteração A2. Foram realizadas 6 medidas de fraturas no afloramento. Apresenta uma família principal de direção N60-70E/90, e fraturas subordinadas de direção N50W/90 e N50E/90. O espaçamento médio das fraturas da família 1 é de meio a um metro, com persistência menor que 5 metros. As fraturas encontram-se fechadas e sem preenchimento.

\section{Ponto 09}

Afloramento em chão, próximo ao emboque do túnel. Encontrado litotipo basáltico com grau de alteração A2. Foram realizadas 13 medidas de fraturas no afloramento. Apresenta duas famílias principais, a família 1 de direção N50-60E/90, e a família 2 de direção N70W/90, e fraturas subordinadas. O espaçamento médio das fraturas da família 1 é de meio a um metro, com persistência menor que 5 metros. As fraturas encontram-se fechadas e sem preenchimento. 


\section{Ponto 10}

Afloramento em chão, próximo ao túnel. Encontrado litotipo basáltico com grau de alteração A2. Foram realizadas 10 medidas de fraturas no afloramento. Apresenta duas famílias principais, a família 1 de direção N40-60W/90, e a família 2 de direção N50-60E/90, e fraturas subordinadas de direção N30E/90 e EW/90. O espaçamento médio das fraturas da família 1 é de meio a um metro, com persistência menor que 5 metros. As fraturas encontram-se fechadas e sem preenchimento.

\section{Ponto 11}

Afloramento em chão, próximo ao túnel. Encontrado litotipo basáltico com grau de alteração A2. Foram realizadas 10 medidas de fraturas no afloramento. Apresenta duas famílias principais, a família 1 de direção N30-60W/90, e a família 2 de direção N70-80W/90, e fraturas subordinadas de direção N70E/90 e N20W/90. O espaçamento médio das fraturas da família 1 é de meio a um metro, com persistência menor que 5 metros. As fraturas encontram-se fechadas e sem preenchimento.

\section{Ponto 12}

Afloramento em corte, na margem direita da barragem. Encontrado litotipo basáltico com grau de alteração $A 3$, chegando a A4 em algumas porções, onde se observa decomposição esferoidal da rocha (Figura 13). Foram realizadas 4 medidas de fraturas sub-verticais no afloramento. O corte apresenta direção N50W, e foram observadas fraturas nas direções N40E/90, N65E/90 e N85W/90. O alto grau de alteração do afloramento não permitiu a determinação das condições das fraturas. As fraturas sub-horizontais são predominantes, apresentando uma persistência maior que 5 metros, e espaçamento entre 5 e $15 \mathrm{~cm}$. 

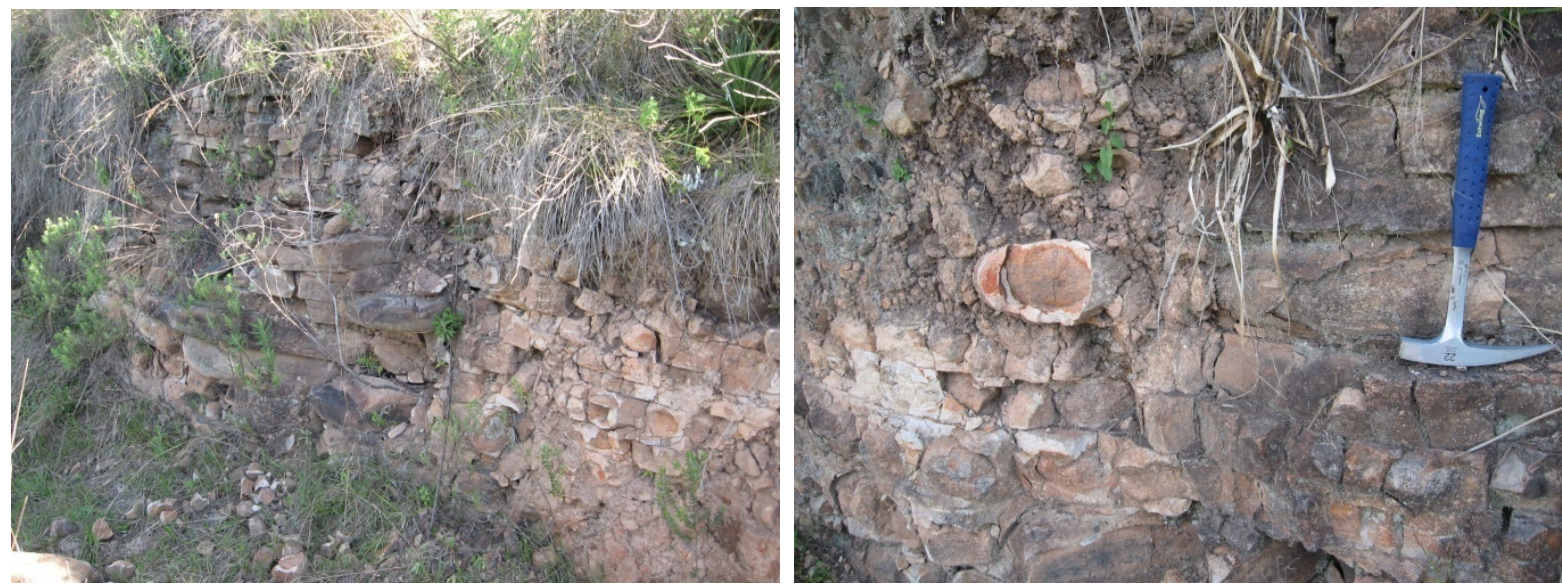

Figura 13 - Afloramento do ponto 12, detalhe para o forte fraturamento sub-horizontal, e para decomposição esferoidal da rocha.

\section{Ponto 13}

Afloramento em chão, na margem direita da barragem, em cota superior à do ponto 12 . Encontrado litotipo basáltico com grau de alteração A2. Foram realizadas 16 medidas de fraturas no afloramento. Apresenta duas famílias principais, a família 1 de direção N2030W/90, e a família 2 de direção N40-50E/90, e fraturas subordinadas. O espaçamento médio das fraturas da família 1 é de meio a um metro, com persistência menor que 5 metros. As fraturas encontram-se fechadas e sem preenchimento.

\section{Ponto 14}

Afloramento em chão, na margem esquerda da barragem. Encontrado litotipo basáltico com grau de alteração A2. Foram realizadas 10 medidas de fraturas no afloramento. Apresenta duas famílias principais, a família 1 de direção N50-60E/90, e a família 2 de direção N30W/90, e fraturas subordinadas de direção N20E/90, N80W/90 e EW/90. O espaçamento médio das fraturas da família 1 é de meio a um metro, com persistência menor que 5 metros. As fraturas encontram-se fechadas e sem preenchimento. 


\subsubsection{Análise estrutural das fraturas}

Como a grande maioria das fraturas apresenta o ângulo de mergulho sub-vertical, optou-se pela apresentação dos resultados em diagrama de rosetas para representar a tendência geral do fraturamento (Figura 14).

A análise da área através de fotografia aérea mostra um forte controle estrutural, estando os rios e drenagens encaixados nestas fraturas. As direções mais marcantes são as N60E e $\mathrm{N} 30 \mathrm{E}$, formando longos alinhamentos, com traços maiores que $3 \mathrm{~km}$, podendo atingir até 5 $\mathrm{km}$ de comprimento, e com espaçamento de 1 a $0,5 \mathrm{~km}$ entre eles. Os alinhamentos de direção N30W também são bem marcados no terreno, formando traços longos, mas com afastamento entre 1,5 a $2 \mathrm{~km}$. Os alinhamentos de direção N80W e EW apresentam traços mais curtos, menores que $1 \mathrm{~km}$, e são bem evidenciados apenas em uma faixa um pouco ao sul da área de estudo.

No diagrama geral da área, com as atitudes de todos os pontos plotadas, pode-se observar que as direções gerais observadas por foto aérea se repetem nas fraturas medidas em campo. A direção N60-50E formando a família principal de fraturas, as direções N80W e N20W também muito importantes na área, com fraturas subordinadas de direções NS. Com os diagramas plotados no mapa de pontos da área (Figura 15), percebe-se que há uma tendência nos pontos próximos aos alinhamentos de que a família principal de fraturas esteja paralela ao alinhamento, confirmando em campo as estruturas observadas por foto aérea. Isso fica bem marcado no ponto 2 ao sul da área; nos pontos 8, 9 e 10 no centro da área; e nos pontos 12 e 13 ao norte. 

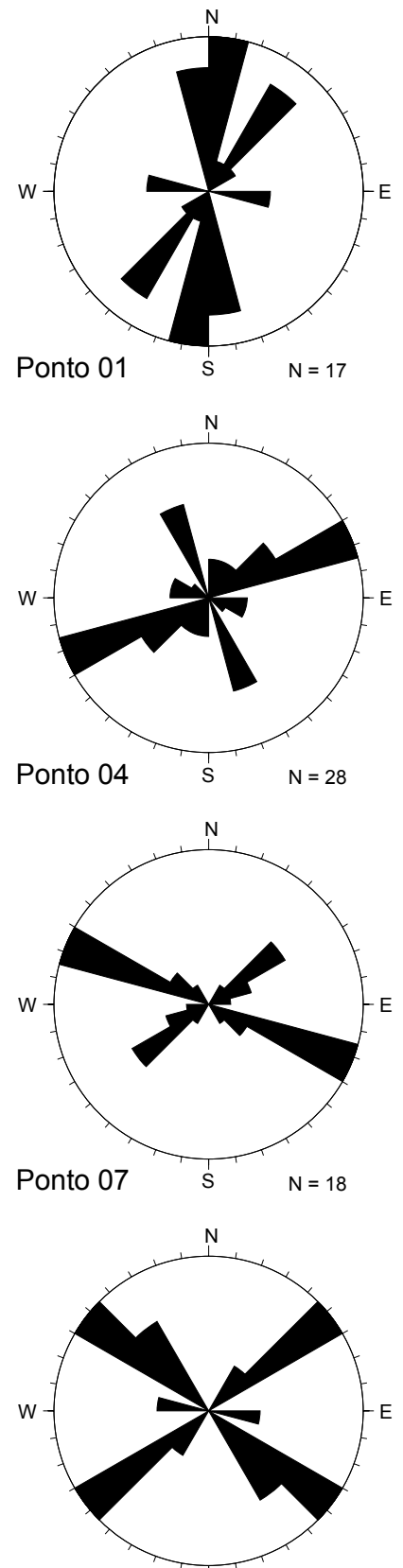

Ponto 10 S N $=10$

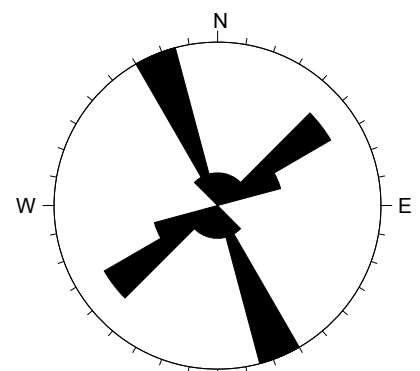

Ponto 13 S $\quad \mathrm{N}=16$
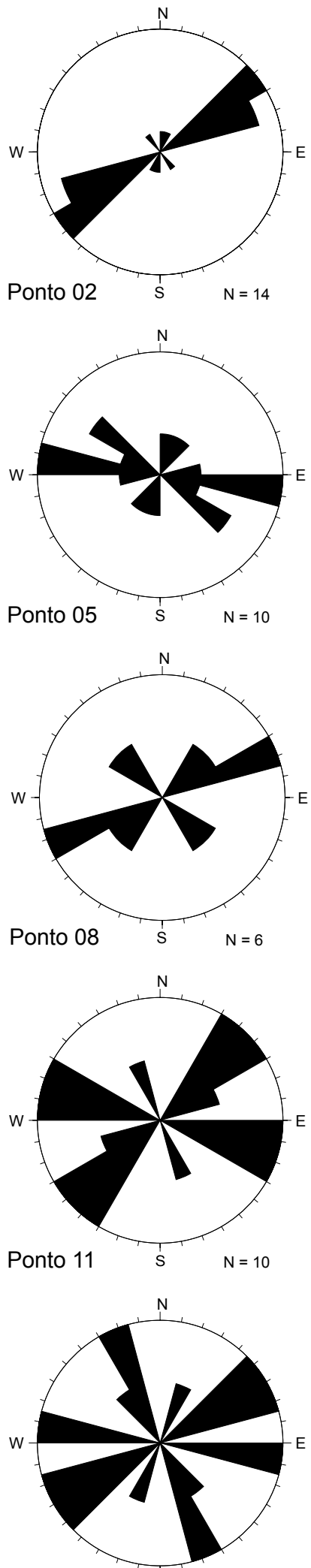

Ponto 14 S N $=10$
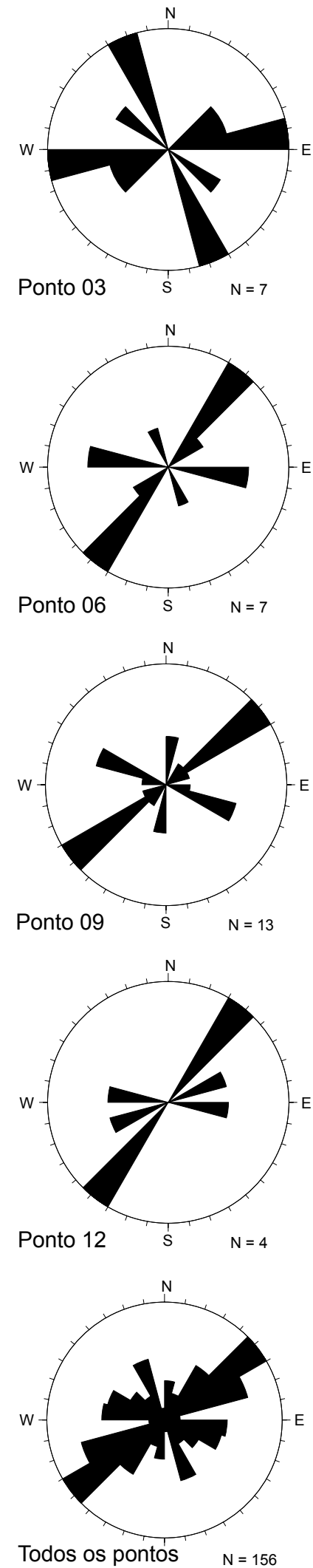

Figura 14 - Diagramas de rosetas das fraturas. ( $N$ = número de medidas) 


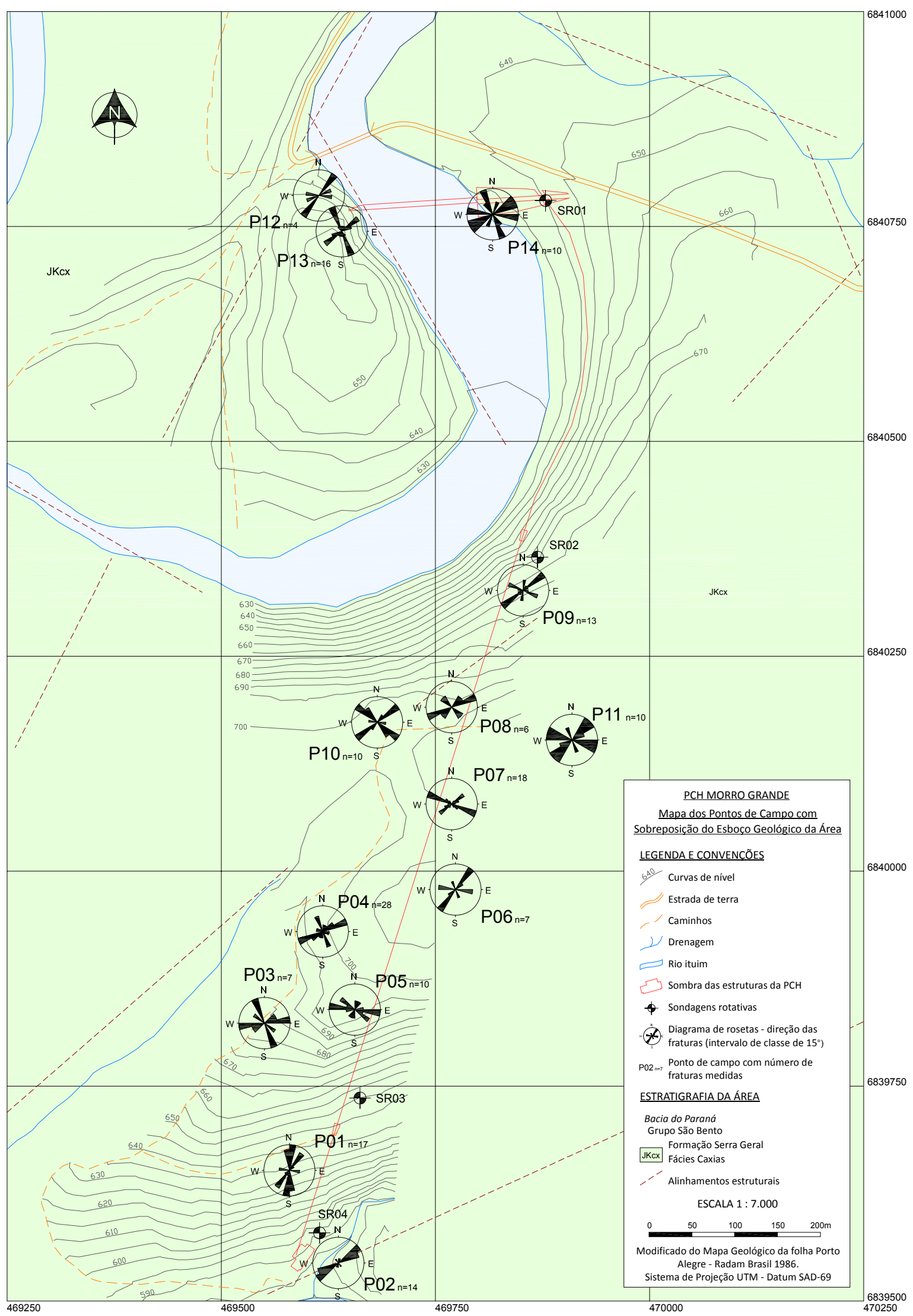

Figura 15 - Mapa de pontos de campo com diagrama de roseta das fraturas sobreposto ao esboço geológico da área. 


\subsection{Descrição das sondagens}

A área dispõe de 4 furos de sondagem rotativa: o SR1 com 12,60 metros localizado na área da barragem (Figura 16); o SR2 com 40,90 metros localizado na área de emboque do túnel (Figura 17 e 16); o SR3 com 23 metros localizado na área de desemboque do túnel (Figura 19); e o SR4 com 22,90 metros localizado na área da casa de força (Figura 20).
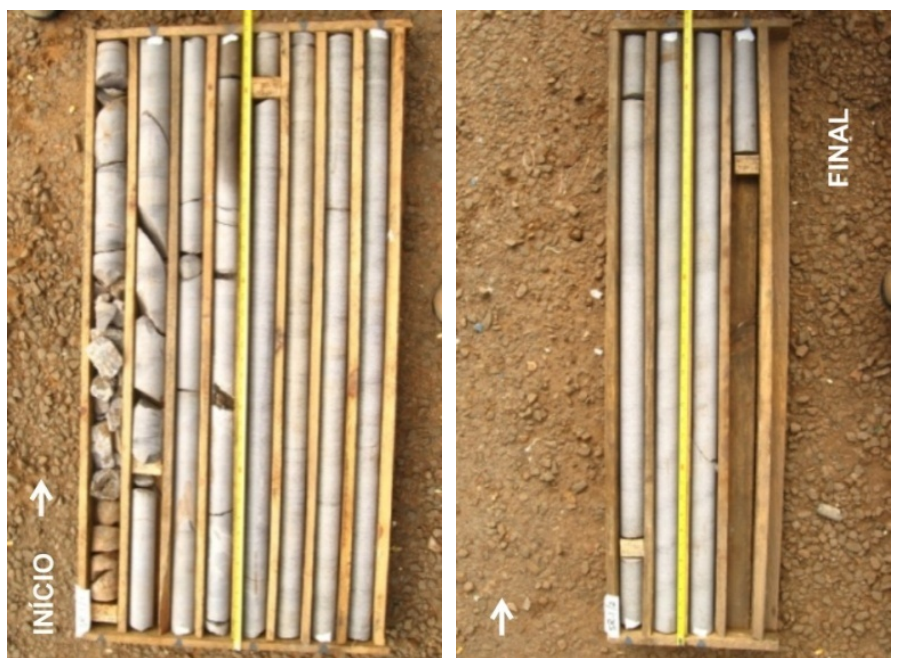

Figura 16 - Foto dos testemunhos da sondagem SR1, caixas 1 e 2.
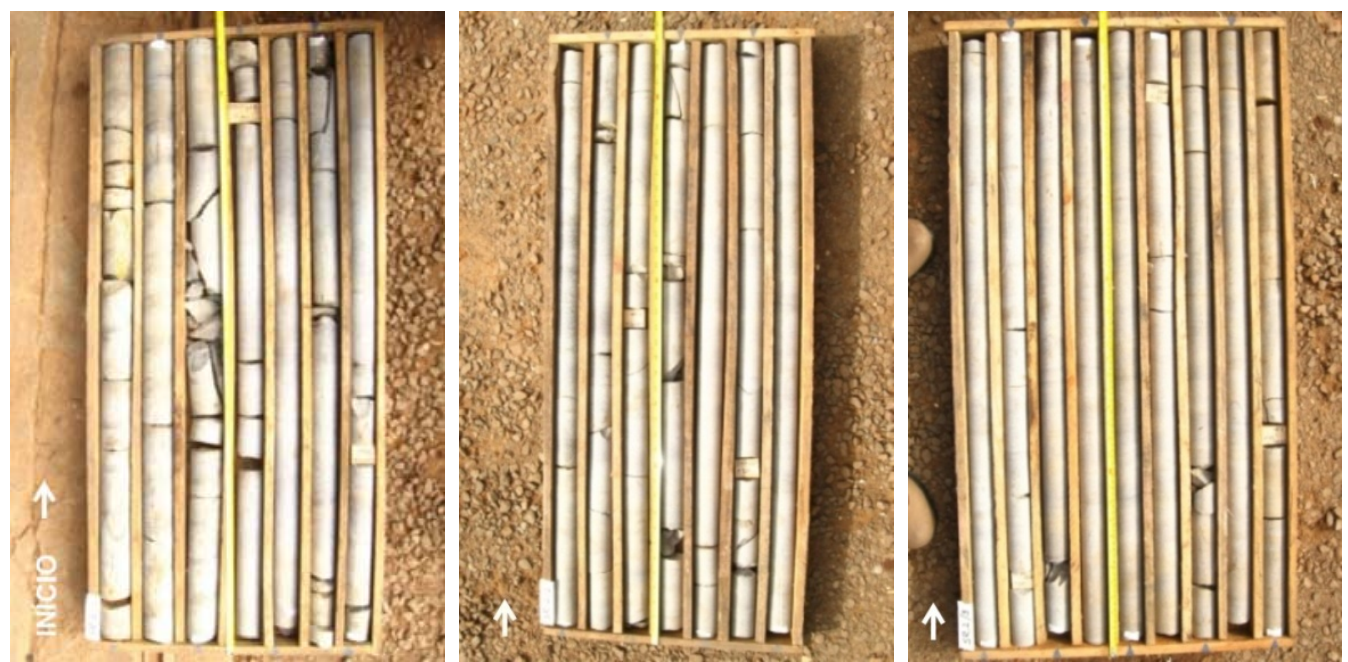

Figura 17 - Foto dos testemunhos da sondagem SR2, caixas 1, 2 e 3. 

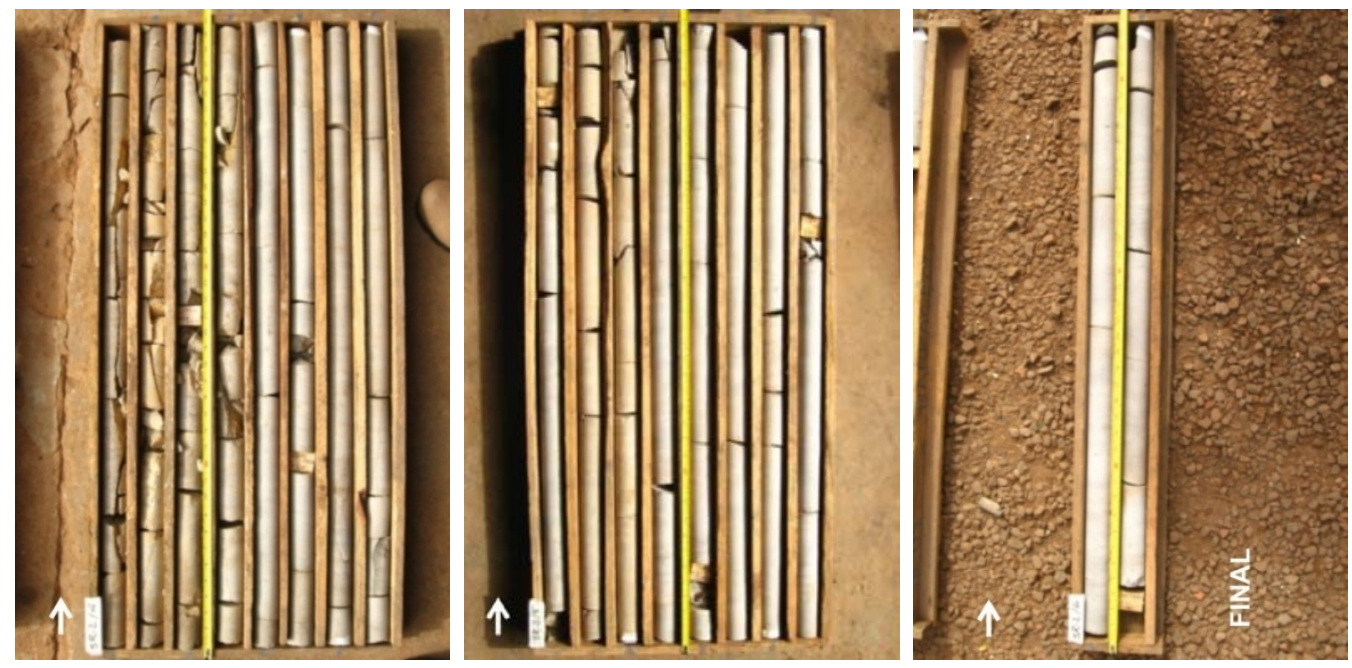

Figura 18 - Foto dos testemunhos da sondagem SR2, caixas 4, 5 e 6.

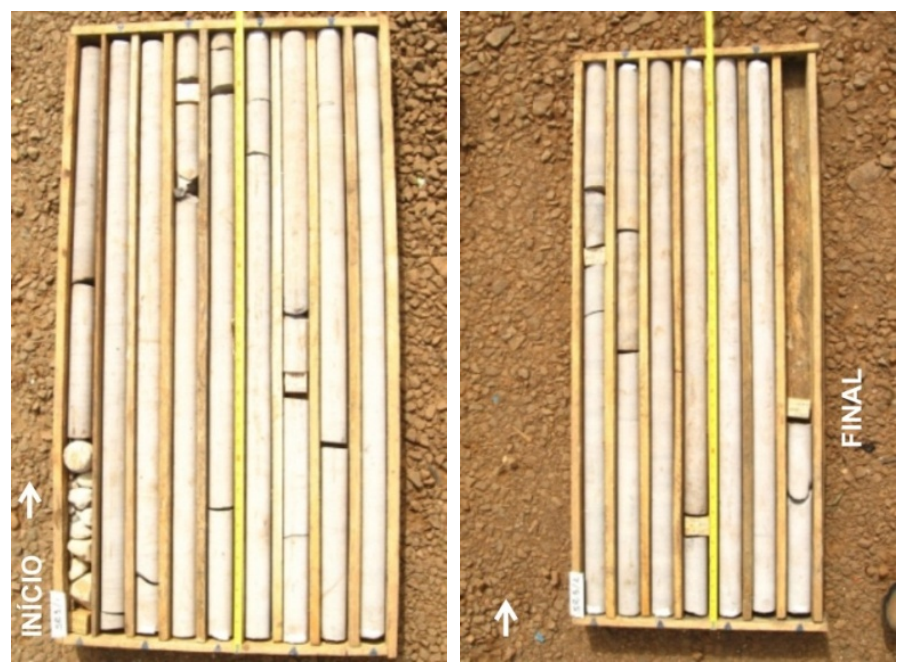

Figura 19 - Foto dos testemunhos da sondagem SR3, caixas 1 e 2.
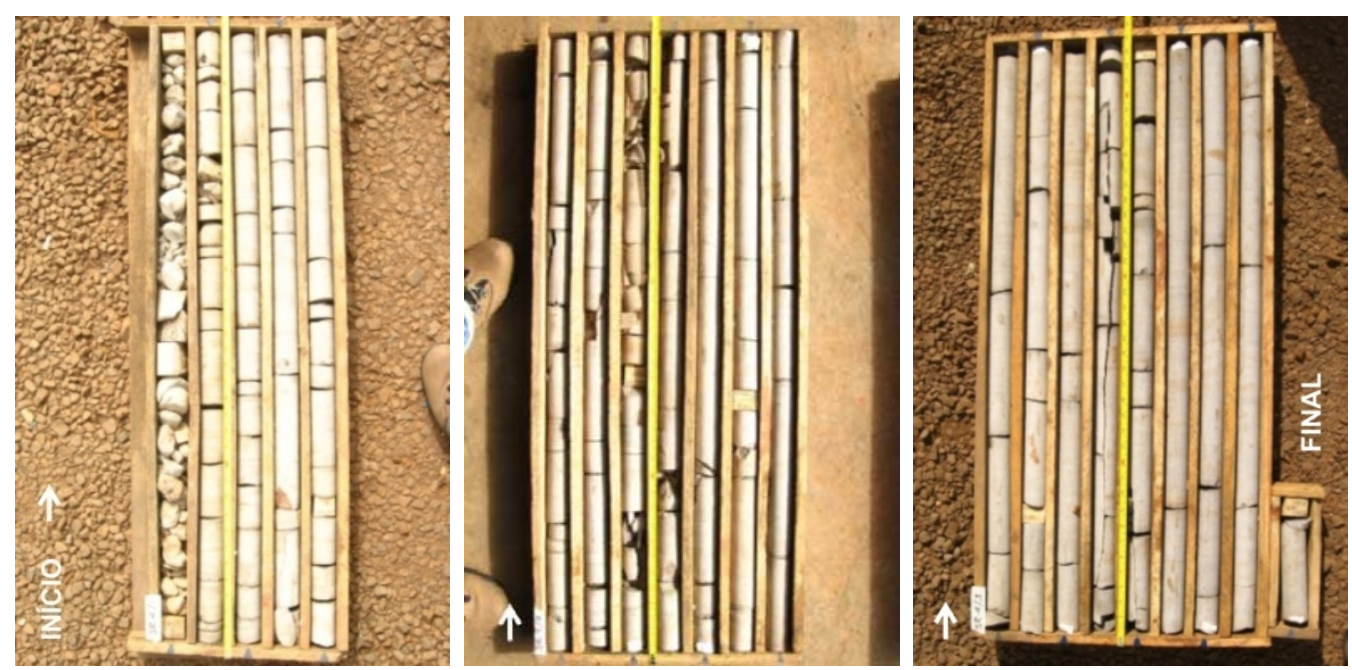

Figura 20 - Foto dos testemunhos da sondagem SR4, caixas 1, 2 e 3. 


\subsubsection{Litologia}

O litotipo perfurado nas quatro sondagens é o mesmo, ocorrendo pequenas variações de textura e coloração. Trata-se de uma rocha basáltica, de coloração cinza clara, de granulação fina a afanítica, de estrutura maciça, provavelmente um dacito. Cortando a rocha ocorrem alguns veios preenchidos por zeólita, que em veios mais abertos podem desenvolver cristais maiores (Figura 21).
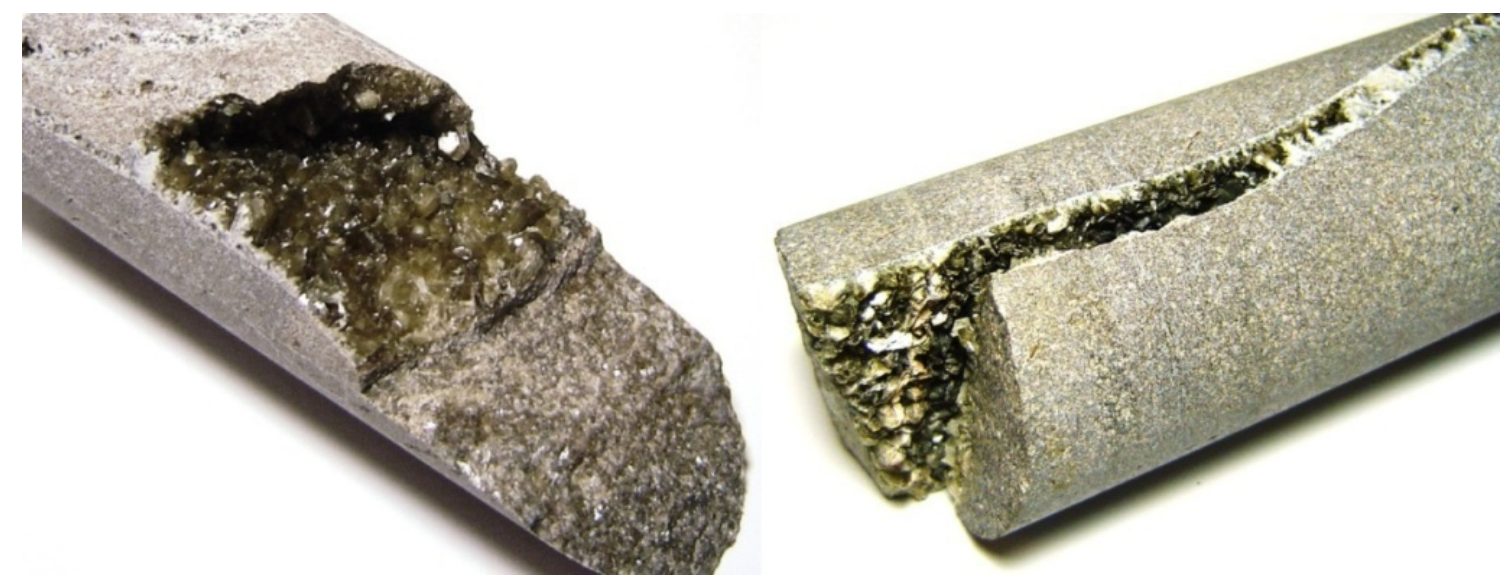

Figura 21 - Amostra de dacito com fratura aberta preenchida por veio de zeólita.

\subsubsection{Grau de alteração}

$\mathrm{Na}$ descrição dos testemunhos foram identificados três graus de alteração (Figura 22). O grau A1 é predominante nas sondagens, estando a maioria das rochas no estado 'praticamente sã', caracterizado por uma alteração insipiente dos feldspatos, e poucas no estado 'sã'. O grau de alteração A2, 'moderadamente alterada', ocorre em poucos trechos, sendo estas rochas caracterizadas por uma alteração mais acentuada dos minerais, e uma descoloração da rocha tendendo para um tom esverdeado. O grau de alteração A3, 'muito alterada', ocorre apenas nas sondagens SR1 e SR4, nas porções mais próximas ao início do furo. Esse grau de alteração é caracterizado por uma intensa alteração dos minerais, e rochas friáveis e muito descoloridas. 
A1 - Sã

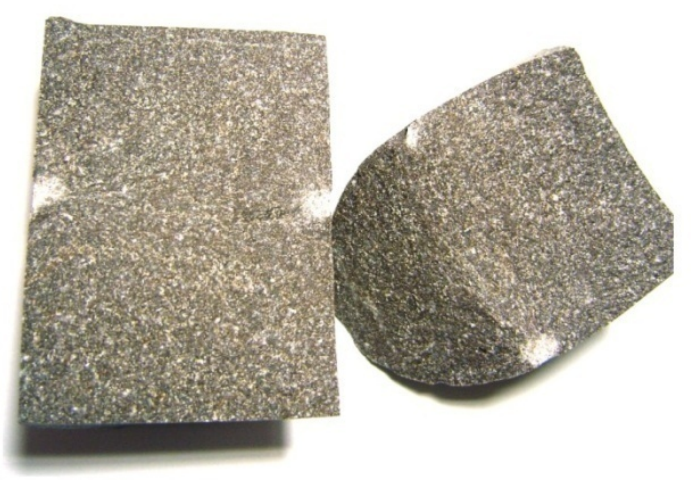

A2 - Moderadamente Alterada

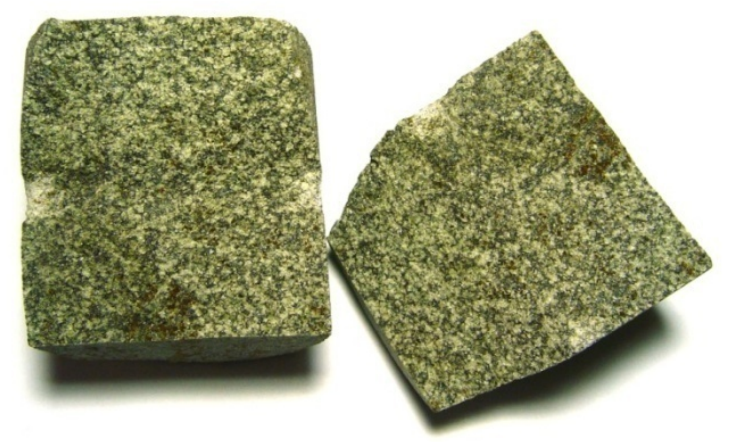

A1 - Praticamente Sã
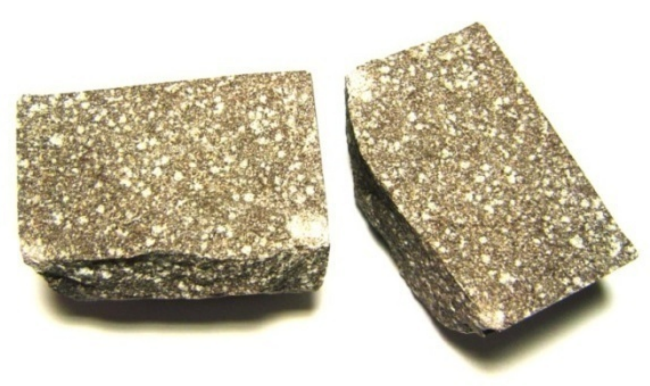

A3 - Muito Alterada
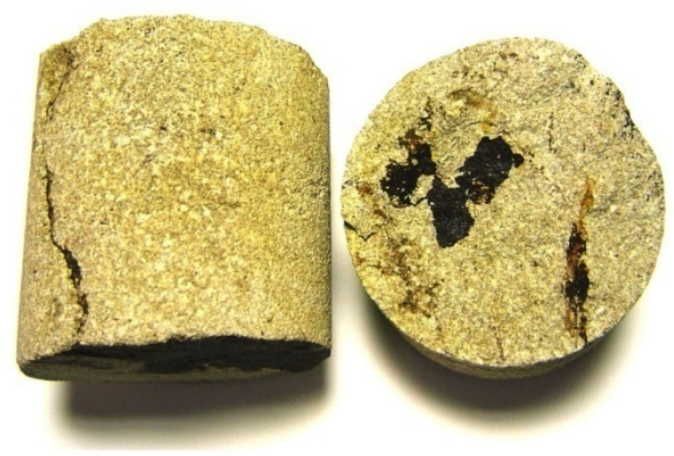

Figura 22 - Amostras de rocha no diferentes graus de alteração encontrados.

\subsubsection{Descontinuidades}

As sondagens apresentam uma predominância de ocorrência de fraturas horizontais, sendo em menor quantidade e muito mais esparsas as fraturas inclinadas. As fraturas verticais, apesar de serem mais difíceis de serem amostradas em furos verticais, mostram-se presentes ao longo de quase todas as sondagens.

A descrição da condição das descontinuidades foi feita em relação a persistência, a abertura, a rugosidade, o preenchimento, e a alteração das paredes da fratura. A Figura 23 mostra os diferentes perfis de rugosidade encontrados nas fraturas descritas. 

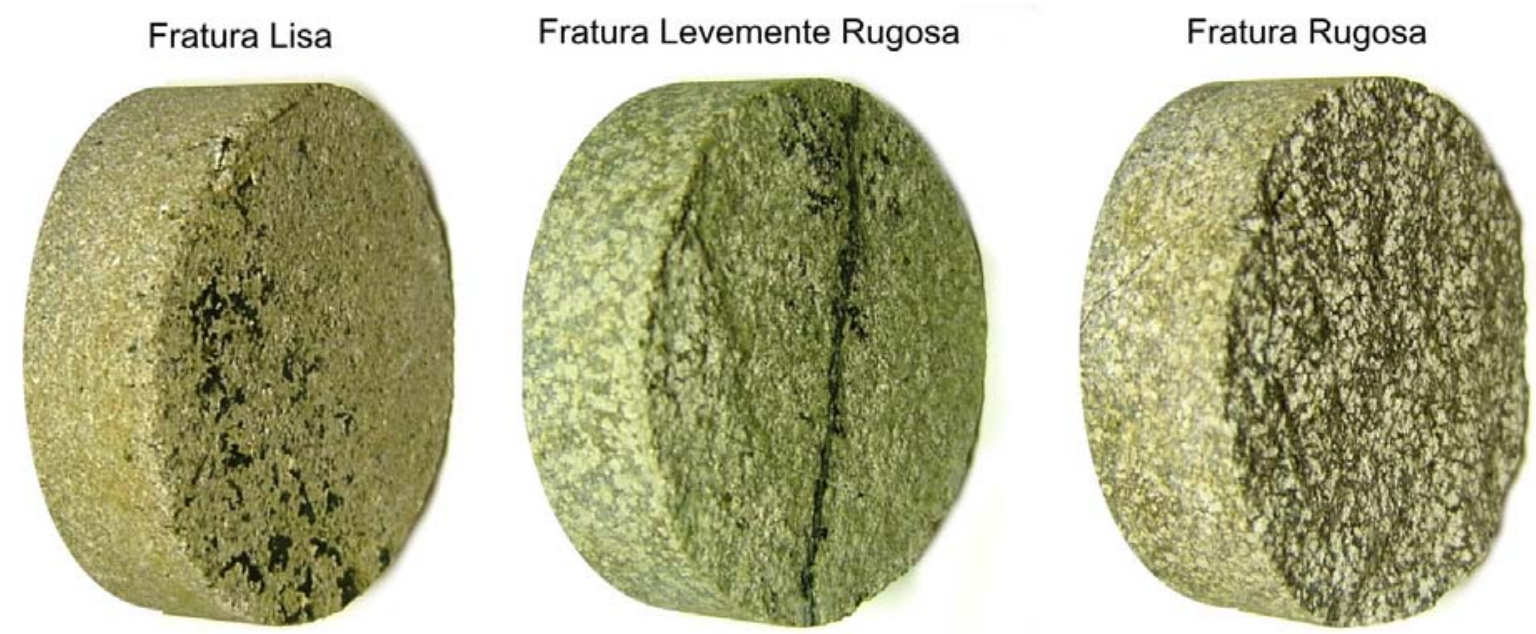

Figura 23 - Exemplos de rugosidade encontrados nas fraturas das sondagens.

A descrição da abertura da fratura é difícil de determinar em amostras de testemunhos, pois a distância original das paredes não é preservada após a retirada dos testemunhos do furo de sondagem. A solução tomada foi verificar o encaixe das duas partes, quando ele se mostrava perfeito foi adotada a abertura menor que $0,1 \mathrm{~mm}$, e quando o encaixe das duas partes não era tão perfeito foi adotada abertura entre 0,1 e $1 \mathrm{~mm}$. Nos casos das amostras fragmentadas foi adotada abertura de 1 a $5 \mathrm{~mm}$. Preferiu-se não adotar em nenhum caso abertura igual a zero.

\subsection{Ensaios de laboratório}

Alguns ensaios e análises de laboratório foram realizados para melhorar a caracterização da rocha, sendo eles a análise petrográfica, e o ensaio de carga puntual, para determinação da resistência da rocha intacta, um dos parâmetros solicitados pela classificação adotada.

\subsubsection{Análise petrográfica}

Foi feita a análise petrográfica da amostra 12 , sendo a rocha identificada como um dacito de coloração marrom acinzentada com pontuações esbranquiçadas, constituída por 
microfenocristais de andesina e diopsídio em matriz hipocristalina formada por quartzo, feldspato alcalino, andesina, minerais opacos e vidro vulcânico. Os microfenocristais perfazem até $15 \%$ da rocha, sendo $10 \%$ andesina e $5 \%$ diopsídio. Apresenta estrutura maciça.

\subsubsection{Ensaio de carga puntual}

A determinação da resistência da rocha intacta foi feita através do ensaio de compressão puntual, que foi escolhido por ser um ensaio simples e de baixo custo. $O$ objetivo foi determinar a resistência da rocha em seus diferentes graus de alteração. Ao todo foram selecionadas 13 amostras no grau de alteração $A 1,17$ no $A 2$ e 3 no $A 3$.

O baixo número de amostras no grau de alteração A3 deve-se ao fato da pouca quantidade de rochas neste grau de alteração com as dimensões necessárias para o ensaio. A diferença entre o número de amostras no grau A1 (13) e A2 (17) deve-se ao fato que a maioria das amostras apresenta um comprimento maior que o solicitado pelo ensaio, podendo ser serradas em 2 ou 3 partes. Depois de serradas as amostras, foi obtido um número de 25 amostras no grau A1, e 27 amostras no grau A2. Das 55 amostras ensaiadas, 4 falharam por apresentarem padrão de rompimento inválido, ou seja, a ruptura não ocorreu em toda a seção diametral da amostra.

Desta forma, obteve-se para as rochas com alteração A1 um índice de carga puntual médio $I_{s(50)}$ igual a $11,13 \mathrm{MPa}$, e para as com alteração A2 igual a 6,74 MPa. Para as A3 o valor obtido foi muito baixo, não sendo adequado utilizar valores de carga puntual, sendo neste caso mais indicado o uso da compressão uniaxial. As planilhas completas com os dados obtidos nos ensaios encontram-se no anexo A. 


\section{APLICAÇÃO DO SISTEMA RMR}

A classificação pelo sistema RMR é comumente aplicada a regiões estruturais prédeterminadas, que apresentem características mais ou menos homogêneas. Considerando que na área em estudo ocorre apenas um tipo litológico, uma pré-divisão do maciço resultaria na identificação de dois grandes compartimentos, o maciço rochoso e terroso. Para a subdivisão do maciço rochoso teriam que ser analisadas características como fraturamento e alteração. Desta forma optou-se por testar o sistema RMR, sem a pré-divisão do maciço rochoso, aplicando a classificação continuamente ao longo das sondagens, uma vez que as alterações propostas visam melhorar a identificação daquelas características. Com este procedimento as variações dos parâmetros determinam a segmentação da sondagem, onde o valor RMR é calculado para cada segmento. Para que se possa verificar o efeito causado pelas modificações propostas, a classificação das sondagens foi feita tanto com estas modificações (segmentada), quanto na forma original (por manobras), onde a subdivisão é dada principalmente pelo comprimento das manobras devido ao uso do RQD.

\subsection{Parâmetros}

Quanto a caracterização dos parâmetros ao longo das sondagens destacam-se os seguintes aspectos:

- Para rochas com grau de alteração A1 o índice puntiforme médio é de 11,13 com peso relativo igual a 15. Para rochas com grau de alteração A2 o índice puntiforme médio é de 6,74 com peso relativo igual a 12 . As rochas com grau de alteração A3 têm um índice puntiforme médio inferior a 1, sendo que Bieniawski (1989) aconselha neste caso que se utilize a compressão simples. Visto que se dispunham poucas amostras neste grau de 
alteração, não foi possível realizar os ensaios de compressão simples, convencionando-se utilizar para as rochas com alteração A3 o valor médio do campo, ou seja, 1.

- Neste estudo optou-se pela utilização do IQR no lugar do RQD, pois o cálculo do IQR é feito para zonas de fraturamento homogêneo, o que evita a diluição das características ruins do maciço, como podem acontecer com a utilização do RQD, que é calculado por manobra.

- A ação da água subterrânea foi determinada através da relação entre a pressão de água e a tensão principal, sendo que a planilha com a memória dos cálculos realizados para cada uma das sondagens encontra-se no Anexo B.

A influência da orientação de descontinuidades foi determinada para cada sondagem, sendo considerada em todos os casos como moderada:

- A sondagem SR1 foi realizada na área da barragem, onde as principais descontinuidades são (i) fraturas sub-horizontais, associadas à (ii) fraturas sub-verticais de direções oblíquas ao eixo da barragem, e em menor número (iii) fraturas sub-verticais subparalelas ao eixo.

- A sondagem SR2 foi realizada no emboque do túnel, onde as principais descontinuidades são (i) fraturas sub-horizontais, associadas à (ii) fraturas sub-verticais de direções oblíquas ao eixo do túnel, e em menor número (iii) fraturas sub-verticais perpendiculares ao eixo.

- A sondagem SR3 foi realizada no desemboque do túnel, onde as principais descontinuidades são (i) fraturas sub-horizontais, associadas à (ii) fraturas sub-verticais de direções oblíquas ao eixo do túnel, e em menor número (iii) fraturas sub-verticais paralelas ao eixo.

- A sondagem SR4 foi realizada na área da casa de força, onde as principais descontinuidades são (i) fraturas sub-horizontais, associadas à (ii) fraturas sub-verticais de direções oblíquas ao eixo do alinhamento. 


\subsection{Classificação das sondagens}

As notas atribuídas a cada um dos parâmetros classificados foram transformadas em planilhas, de forma a facilitar o cálculo da nota final. Abaixo segue como exemplo a planilha utilizada para a sondagem SR1, com as notas obtidas por cada parâmetro, no modelo segmentado proposto neste estudo e no modelo por manobras (Tabela 22). As planilhas de todas as sondagens encontram-se no Anexo C.

As sondagens rotativas analisadas são apresentadas da Figura 24 à Figura 27. No boletim de descrição da sondagem destaca-se: a coluna Nível d'água, onde está representada a variação em profundidade da relação entre a pressão da coluna d'água e a tensão principal; a representação tanto do RQD quanto do IQR; a posição de cada uma das amostras utilizadas para a realização dos ensaios; a representação das fraturas com espaçamento real, e a classificação do espaçamento segundo o sistema RMR, representada por uma escala de cores; a representação da condição das fraturas; e duas colunas onde é representada a classificação da sondagem pelo sistema RMR, uma por segmentos e outra por manobra, para facilitar a comparação dos resultados.

Tabela 22 - Planilha de aplicação do sistema RMR na sondagem SR1. Modelo segmentado e modelo por manobras.

\begin{tabular}{|c|c|}
\hline & SR1 \\
\hline \multicolumn{2}{|c|}{ PARÂMETROS } \\
\hline \multicolumn{2}{|c|}{ Resistência } \\
\hline \multicolumn{2}{|r|}{ RQD } \\
\hline \multicolumn{2}{|c|}{ Espaçamento } \\
\hline \multirow{5}{*}{ 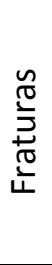 } & Persistência \\
\hline & Abertura \\
\hline & Rugosidade \\
\hline & Preenchimento \\
\hline & Alteração \\
\hline \multicolumn{2}{|r|}{ Água } \\
\hline \multicolumn{2}{|r|}{ Direção } \\
\hline & RMR \\
\hline
\end{tabular}

\begin{tabular}{|c|c|c|c|c|c|c|c|c|c|}
\hline \multicolumn{10}{|c|}{ SEGMENTOS } \\
\hline $\mathbf{1}$ & $\mathbf{2}$ & $\mathbf{3}$ & $\mathbf{4}$ & $\mathbf{5}$ & $\mathbf{6}$ & $\mathbf{7}$ & $\mathbf{8}$ & $\mathbf{9}$ & $\mathbf{1 0}$ \\
\hline 1 & 12 & 15 & 15 & 15 & 15 & 15 & 15 & 15 & 15 \\
\hline 5 & 5 & 17 & 17 & 17 & 20 & 20 & 20 & 20 & 20 \\
\hline 5 & 5 & 8 & 8 & 8 & 15 & 15 & 20 & 15 & 15 \\
\hline 2 & 2 & 2 & 2 & 2 & 2 & 2 & 2 & 2 & 2 \\
\hline 1 & 1 & 4 & 5 & 5 & 5 & 5 & 5 & 5 & 5 \\
\hline 3 & 3 & 3 & 3 & 3 & 3 & 3 & 3 & 3 & 3 \\
\hline 6 & 6 & 6 & 6 & 6 & 6 & 6 & 6 & 6 & 6 \\
\hline 1 & 1 & 5 & 5 & 5 & 5 & 5 & 5 & 5 & 5 \\
\hline 15 & 15 & 15 & 15 & 15 & 15 & 10 & 7 & 7 & 4 \\
\hline-7 & -7 & -7 & -7 & -7 & -7 & -7 & -7 & -7 & -7 \\
\hline 32 & $\mathbf{4 3}$ & $\mathbf{6 8}$ & $\mathbf{6 9}$ & $\mathbf{6 9}$ & $\mathbf{7 9}$ & $\mathbf{7 4}$ & $\mathbf{7 6}$ & $\mathbf{7 1}$ & $\mathbf{6 8}$ \\
\hline
\end{tabular}

\begin{tabular}{|c|c|c|c|c|}
\hline \multicolumn{5}{|c|}{ MANOBRAS } \\
\hline $\mathbf{1}$ & $\mathbf{2}$ & $\mathbf{3}$ & $\mathbf{4}$ & $\mathbf{5}$ \\
\hline- & 15 & 15 & 15 & 15 \\
\hline- & 8 & 17 & 20 & 20 \\
\hline- & 8 & 10 & 15 & 15 \\
\hline- & 2 & 2 & 2 & 2 \\
\hline- & 4 & 5 & 5 & 5 \\
\hline- & 3 & 3 & 3 & 3 \\
\hline- & 6 & 6 & 6 & 6 \\
\hline- & 5 & 5 & 5 & 5 \\
\hline- & 15 & 15 & 10 & 7 \\
\hline- & -7 & -7 & -7 & -7 \\
\hline $\mathbf{0}$ & $\mathbf{5 9}$ & $\mathbf{7 1}$ & $\mathbf{7 4}$ & $\mathbf{7 1}$ \\
\hline
\end{tabular}


Figura 24 - Boletim de descrição da sondagem SR1, com a classificação RMR. 
Figura 25 - Boletim de descrição da sondagem SR2, com a classificação RMR. 
Figura 26 - Boletim de descrição da sondagem SR3, com a classificação RMR. 
Figura 27 - Boletim de descrição da sondagem SR4, com a classificação RMR. 
As classes de maciço da classificação RMR são representadas por uma escala de cores: azul - muito bom; verde - bom; amarelo - regular; e laranjado - pobre. Nenhuma classe foi identificada como muito pobre.

\subsection{Classificação dos afloramentos}

A aplicação parcial do sistema RMR nos afloramentos levou a atribuição de pesos aos parâmetros descritos em campo: espaçamento, persistência, abertura, preenchimento e orientação das descontinuidades. A Tabela 23 apresenta as notas atribuídas a cada parâmetro, para cada ponto de campo.

Tabela 23 - Planilha de atribuição dos pesos relativos aos afloramentos de campo.

\begin{tabular}{|c|c|c|c|c|c|c|c|c|c|c|c|c|c|c|}
\hline \multirow{2}{*}{ PARÂMETROS } & \multicolumn{14}{|c|}{ NÚMERO DO PONTO DE CAMPO } \\
\hline & 1 & 2 & 3 & 4 & 5 & 6 & 7 & 8 & 9 & 10 & 11 & 12 & 13 & 14 \\
\hline Espaçamento & 15 & 15 & 15 & 15 & 15 & 15 & 15 & 15 & 15 & 15 & 15 & 8 & 15 & 15 \\
\hline Persistência & 4 & 4 & 4 & 4 & 4 & 4 & 4 & 4 & 4 & 4 & 4 & 1 & 4 & 4 \\
\hline Abertura & 5 & 5 & 5 & 1 & 5 & 1 & 5 & 5 & 5 & 5 & 5 & - & 5 & 5 \\
\hline Preenchimento & 6 & 6 & 6 & 2 & 6 & 2 & 6 & 6 & 6 & 6 & 6 & - & 6 & 6 \\
\hline Direção & -7 & -7 & -2 & -2 & -2 & -12 & -2 & -2 & -2 & -2 & -2 & -15 & -2 & -2 \\
\hline
\end{tabular}




\section{INTEGRAÇÃO DOS RESULTADOS EM SEÇÕES TIPO}

Foram elaboradas duas seções tipo ao longo dos eixos das principais estruturas previstas no projeto da PCH Morro Grande, uma das seções foi feita ao longo do eixo da barragem, possuindo uma extensão total de 330 metros. A outra seção representa o circuito hidráulico da $\mathrm{PCH}$ (canal e túnel de adução, conduto forçado e casa de força) com uma extensão total de 1330 metros. Esta seção não é totalmente retilínea, acompanhando um trecho curvo do canal de adução. As seções são as mesmas utilizadas para o projeto de engenharia, facilitando a integração dos resultados da caracterização geotécnica com os aspectos construtivos da obra. O maciço terroso não foi classificado nas seções, por esse motivo apresentando-se como cobertura de solo indiferenciada.

Os pontos de campo, por não serem coincidentes com os traçados das seções, foram transportados para locais da seção de mesma cota. Os pontos 3, 4, 10 e 11 foram desconsiderados por estarem muito distantes da linha da seção.

As sondagens e os pontos de campo foram relacionados de acordo com a proximidade entre si, sendo a sondagem SR1 relacionada com os pontos 12, 13 e 14, a SR2 com os pontos 7, 8 e 9, a SR3 com os pontos 1, 5 e 6, e a SR4 com o ponto 2. Os resultados obtidos neste procedimento foram:

- Ponto 1 x SR3 - A nota atribuída para a influência da orientação das descontinuidades apresenta uma redução de 2 pontos ao longo de toda a sondagem. Essa redução na nota final não causa alteração das classes do maciço.

- Ponto 2 x SR4 - Não ocorre alteração das notas dos parâmetros.

- Ponto 5 x SR3 - Não ocorre alteração das notas dos parâmetros. 
- Ponto 6 x SR3 - Ocorre redução das notas atribuídas para abertura (- 4 pontos), preenchimento (- 4 pontos), e orientação (- 7 pontos). A redução da nota da influência da orientação deve-se a direção principal das fraturas no ponto 6 que é paralela à direção do túnel, caracterizando uma situação muito desfavorável. Essa redução de 15 pontos na nota final causou a alteração das classes de maciço, com os segmentos classificados como 'muito bom' passando para 'bom' e os classificados como 'bom' para 'regular'.

- Ponto 7, 8 e 9 x SR2 - Não ocorre alteração das notas dos parâmetros.

- Ponto 12 x SR1 - As informações do ponto 12 não puderam ser correlacionadas com as da sondagem SR1, pois as descontinuidades classificadas no afloramento são subhorizontais.

- Ponto 12 x SR2 - As informações do ponto 12 apresentam certa correlação com os segmentos 21 e 22 da sondagem SR2, caracterizado por um forte fraturamento sub-vertical, e apresentando-se na mesma cota altimétrica, entre 642 e $647 \mathrm{~m}$, sugerindo uma continuidade lateral para o fraturamento sub-horizontal.

- Ponto 13 e 14 x SR1 - Não ocorre alteração das notas dos parâmetros.

A seção da barragem é apresentada na Figura 28, e a seção do circuito hidráulico é apresentada na Figura 29. Para uma melhor visualização dos perfis foi empregado um exagero em relação a escala horizontal de 4 vezes. Destaca-se o caráter inferido do contato entre os compartimentos no interior do maciço.

Nas duas seções destaca-se a presença de um compartimento sub-horizontal definido entre as cotas 642 e $647 \mathrm{~m}$, caracterizado por um forte fraturamento sub-horizontal com espaçamento entre 5 e $15 \mathrm{~cm}$, verificado na sondagem SR2 e no ponto de campo 12 . Na seção do circuito hidráulico destaca-se a influência do ponto 6 na determinação da não continuidade lateral dos compartimentos de classe 'muito bom' definidos na sondagem SR3, e a continuidade do compartimento de classe 'regular' definido na sondagem SR2. 


\section{PARÂMETROS GEOMECÂNICOS}

A estimativa dos parâmetros geomecânicos pode ser obtida para cada classe de maciço através da Tabela 21 (página 30) proposta por Bieniawski (1989), ou pelo cálculo direto desses valores pelas equações propostas por Sen e Sadagah (2003, ver página 31). Para cada um dos compartimentos principais encontrados nas seções da barragem e do circuito hidráulico, foram calculados os parâmetros geomecânicos com base nas equações das páginas 31 e 32, conforme apresentado na Tabela 24.

Comparando os resultados obtidos com os propostos por Bieniawski (1989), observa-se que os valores encontrados através das equações 10, 11 e 12 mostram-se discordantes dos encontrados na Tabela 21. Os valores de vão da seção e coesão apresentam-se em média mais baixos, enquanto os valores de ângulo de atrito apresentam-se em média mais altos. Os valores de tempo de auto-sustentação mostram uma correlação melhor. Devido a essa divergência de resultados, é preferível a utilização dos valores sugeridos pelo sistema RMR (Tabela 21) para a estimativa dos parâmetros que se apresentaram discordantes.

Tabela 24 - Parâmetros geomecânicos calculados a partir da nota RMR.

\begin{tabular}{|c|c|c|c|c|c|c|c|c|}
\hline & \multicolumn{2}{|c|}{ Barragem } & \multicolumn{2}{c|}{ Túnel - emboque } & \multicolumn{2}{c|}{ Túnel - desemboque } & \multicolumn{2}{c|}{ Casa de Força } \\
\hline Compartimento & Regular & Bom & Regular & Bom & Muito Bom & Bom & Pobre & Regular \\
\hline RMR médio & $\mathbf{5 9}$ & $\mathbf{7 2}$ & $\mathbf{5 8}$ & $\mathbf{7 0}$ & $\mathbf{8 3}$ & $\mathbf{7 5}$ & $\mathbf{2 7}$ & $\mathbf{5 1}$ \\
\hline Auto-sustentação & - & - & 25 dias & $\mathbf{7}$ meses & 6 anos & 17 meses & - & - \\
\hline Vão livre de seção (m) & - & - & 3,2 & 3,9 & 4,6 & 4,2 & - & - \\
\hline Coesão (KPa) & 214 & 261 & 210 & 254 & 301 & 272 & 98 & 185 \\
\hline $\begin{array}{c}\text { Ângulo de atrito } \\
\text { Módulo de }\end{array}$ & $40^{\circ}$ & $43^{\circ}$ & $40^{\circ}$ & $43^{\circ}$ & $46^{\circ}$ & $44^{\circ}$ & $32^{\circ}$ & $38^{\circ}$ \\
\hline $\begin{array}{c}\text { Meformabilidade (GPa) } \\
\text { deformen }\end{array}$ & 18 & 44 & 16 & 40 & 66 & 50 & 3 & 11 \\
\hline
\end{tabular}


Figura 28 - Seção da barragem com compartimentação pelo sistema RMR. 
Figura 29 - Seção do circuito hidráulico com compartimentação pelo sistema RMR. 


\section{ANÁLISE DOS RESULTADOS}

\subsection{Classificação RMR aplicada às sondagens}

A aplicação do sistema RMR nas sondagens (Figura 24 a Figura 27) resultou na classificação linear do maciço rochoso em 5 classes, que são definidas de acordo com o intervalo de notas obtidas, como 'muito pobre', 'pobre', 'regular', 'bom' e 'muito bom', dos valores mais baixos para os mais altos.

Na sondagem SR1 o maciço foi classificado como 'bom', sendo apenas a porção superficial mais alterada, inferior a 1 metro, classificada como 'regular' e 'pobre'.

Na sondagem SR2 o maciço apresenta uma predominância da classe 'bom', ocorrendo intercalações com zonas 'regular' e 'muito bom'. A ocorrência de zonas de classe regular está relacionada diretamente à porções com fraturamento mais elevado, e à ocorrência de rochas no grau de alteração A2 entre a profundidade de 23 e 27 metros. Já a ocorrência de zonas de classe 'muito bom' está relacionada à porções de muito baixo fraturamento.

$\mathrm{Na}$ sondagem SR3 o maciço apresenta no primeiro meio metro uma classe 'regular', relacionada ao grau de alteração A2 da rocha. Predomina a classe de maciço 'muito bom' com intercalações de zonas de classe 'bom', relacionadas à ocorrência de regiões mais fraturadas.

Na sondagem SR4 o maciço foi classificado como 'regular', o que se deve principalmente ao elevado grau de fraturamento e às condições das fraturas. Na porção superficial ocorre uma classe 'pobre' de cerca de 1,7 metros, relacionada ao grau de alteração A3 da rocha. 


\subsection{Comparação: Modelo Segmentado X Modelo por Manobra}

O resultado final da compartimentação das sondagens mostra que as alterações propostas melhoram a sensibilidade do sistema às variações dos parâmetros.

$\mathrm{Na}$ sondagem SR1, onde se tem bem definida a condição pior do maciço no primeiro metro pelo modelo segmentado, no modelo por manobra essa informação é diluída nas características melhores da rocha no restante da manobra, deixando todo o trecho da manobra na classe 'regular'. No restante da sondagem não há diferença entre os dois modelos, pois o maciço se apresenta bem homogêneo.

$\mathrm{Na}$ sondagem SR2, onde se têm definidas diversas zonas de classes de maciço pelo modelo segmentado, no modelo por manobras essas informações são homogeneizadas, sendo o maciço classificado quase que inteiramente como 'bom'. Entre a profundidade de 23 e 27 metros, onde ocorrem rochas no grau de alteração A2, o modelo por manobra consegue detectar a ocorrência da zona mais fraturada.

Na sondagem SR3, o maciço antes classificado com 'muito bom' com algumas intercalações de zonas da classe 'bom', passa a ser classificado totalmente como de classe 'bom', não sendo identificada a porção superficial de características piores.

Na sondagem SR4, não ocorre muita variação de um modelo para o outro, principalmente pela grande homogeneidade do maciço. Ocorre apenas uma redução da zona inicial de classe 'pobre', continuando o restante do maciço classificado como de classe 'regular'.

Observa-se que a aplicação do sistema RMR no modelo por manobras apresenta a tendência de homogeneizar as características do maciço rochoso dentro do comprimento da manobra, o que ocorre também em outros modelos de aplicação, seja por segmentos prédefinidos, ou em zonas homogêneas. 
A aplicação do sistema RMR no modelo segmentado, onde são identificadas primeiramente as variações das características do maciço, permite que os segmentos sejam determinados de maneira a não englobarem características diferentes de um mesmo parâmetro, evitando a homogeneização das informações.

\subsection{Classificação RMR aplicada aos afloramentos}

A aplicação do sistema RMR nos afloramentos rochosos teve como objetivo auxiliar a interpolação da classificação das sondagens, e foi feita de forma parcial, classificando apenas os parâmetros que pudessem refletir características internas do maciço. Os parâmetros considerados são os relacionados às descontinuidades, por apresentam continuidade espacial. Destes, os que puderam ser determinadas em campo foram o espaçamento, a persistência, a abertura, o preenchimento, e a orientação. Todos estes parâmetros, exceto a influência da orientação, representam 38 pontos pela classificação RMR, suficientes para causar uma mudança de classe de maciço, que varia a cada 20 pontos.

De maneira geral, os pesos atribuídos aos parâmetros classificados nos afloramentos de campo apresentam valor igual ou maior que os atribuídos aos classificados nas sondagens. As exceções ocorrem nos pontos 4 e 6 , onde são observadas fraturas abertas e preenchidas por material argiloso, e no ponto 12, onde é observado um fraturamento horizontal com espaçamento entre 5 e 15 centímetros.

A atribuição de pesos para a influência da orientação das descontinuidades, em relação ao fraturamento sub-vertical, permitiu que se definisse a variação do parâmetro ao longo da seção. Como exemplo destaca-se o ponto 6 , onde a direção principal das fraturas é paralela ao eixo do túnel, caracterizando uma condição muito desfavorável, enquanto que nos outros pontos de campo as fraturas perpendiculares ao eixo caracterizam uma condição favorável. 


\subsection{Integração em seções tipo}

Para a obtenção da compartimentação final do maciço rochoso, a classificação RMR das sondagens foi plotada nas seções tipo, e integrada com os dados obtidos no mapeamento de campo. A integração foi feita com a interpolação da classificação das sondagens, que foi cruzada com a classificação feita para os pontos de campo, prevalecendo a condição pior do maciço, ou seja, o peso de valor mais baixo.

O cruzamento da interpolação da classificação das sondagens com a classificação dos afloramentos só foi possível porque os parâmetros classificados nos pontos de campo estão relacionados às fraturas sub-verticais, às quais se admite certa continuidade espacial. Desta forma, as informações dos pontos de campo permitiram a correção da interpolação da classificação, determinando a continuidade, ou não, dos compartimentos definidos no interior do maciço.

A compartimentação do maciço rochoso na seção da barragem foi baseada na classificação de apenas uma sondagem, a SR1 localizada na margem esquerda, e na descrição de 3 afloramentos de campo, pontos 12, 13 e 14 .

No ponto 12 o fraturamento principal identificado é sub-horizontal, diferente dos outros pontos onde o fraturamento principal é sub-vertical, não sendo possível a sua correlação com a sondagem SR1. Contudo, observou-se uma forte correlação deste afloramento com a faixa descrita na sondagem SR2 de mesma cota, entre 642 e $647 \mathrm{~m}$. Na encosta de desemboque do túnel observa-se uma quebra de relevo na mesma cota, reforçando a idéia de que nesta cota ocorre uma zona de fraturamento sub-horizontal intenso, caracterizado por um espaçamento entre 5 e 15 centímetros. Por esse motivo as seções da barragem e do circuito hidráulico apresentam um compartimento de classe 'regular' entre essas cotas. 
O ponto 13 , localizado próximo ao ponto 12 , mas em cota superior, bem como o ponto 14 , localizado em cota inferior, apresentam fraturamento principal sub-vertical, que puderam ser correlacionadas com a classificação da sondagem SR1. Como o confronto dos pesos dos parâmetros classificados nesses pontos com os da sondagem SR1 não causaram modificação da classe, o maciço abaixo da cota 640 , na seção da barragem, foi mantido com a classificação obtida na sondagem SR1, de classe 'bom'. A porção superficial do maciço, no leito do rio, foi mantida como de classe 'regular', conforme identificado na sondagem SR1, admitindo-se que as regiões superficiais apresentam condições piores dadas principalmente pelo avanço da capa de alteração.

$\mathrm{Na}$ seção do circuito hidráulico a compartimentação do maciço rochoso foi baseada na classificação das 4 sondagens, e na descrição de 8 afloramentos de campo, e se ateve as áreas próximas às sondagens, e nas regiões das estruturas como canal, túnel e conduto forçado.

A comparação dos pesos dos parâmetros classificados nos afloramentos dos pontos 2, 5, 7, 8, 9 e 14, com os classificados nas sondagens não causa a alteração da classificação RMR das sondagens. A comparação do ponto 1 com a sondagem SR3 mostra uma redução de 2 pontos na classificação da sondagem, mas não causa a mudanças de classes. A comparação do ponto 6 com a sondagem SR3 mostra uma redução de 15 pontos, causando mudanças de classes em toda a classificação da sondagem.

A alteração das classes de maciço obtidas na comparação do ponto $6 \mathrm{com}$ a sondagem SR3 determinaram a menor continuidade lateral dos compartimentos de classe 'muito bom' definidos na sondagem SR3, a maior continuidade do compartimento de classe 'regular' definido na sondagem SR2 na cota 635. Na encosta do conduto forçado, entre as sondagens SR2 e SR3, foi definido um compartimento de transição de classe 'bom' entre os compartimentos de classe 'muito bom' e 'regular'. 


\subsection{Compartimentação do maciço rochoso}

A compartimentação do maciço rochoso, ao longo das seções levantadas, mostra a variação da qualidade do maciço, representada pelas diferentes classes definidas pelo sistema RMR. Os compartimentos foram determinados de acordo com a distribuição espacial das classes encontradas com a classificação do maciço rochoso. Das 5 classes definidas pelo sistema RMR, apenas uma não foi encontrada, a classe 'muito pobre'. Nas seções da barragem (Figura 28) e circuito hidráulico (Figura 29), além dos compartimentos de classe 'muito bom', 'bom', 'regular' e 'pobre', difere-se ainda a cobertura de solos indiferenciada.

Na seção da barragem definem-se dois compartimentos de classe 'pobre' na porção superficial do maciço, associados à ação intempérica mais intensa nesta porção. 0 compartimento de classe 'regular', entre as cotas 642 e $647 \mathrm{~m}$, é definido devido à ocorrência de uma zona de fraturamento sub-horizontal intenso neste nível, e é estendido na porção superficial do maciço no leito do rio devida ao intemperismo mais intenso nesta área. O compartimento de classe 'bom' é definido com base na sondagem SR1 na margem esquerda, sendo esta condição também atribuída para as porções sub-superficiais do leito do rio e da margem direita.

$\mathrm{Na}$ seção do circuito hidráulico observa-se que na região do canal adutor ocorre um compartimento delgado superficial de classe 'pobre', e que em sub-superfície predominam as classes 'regular' e 'bom'. Na região do túnel destaca-se um compartimento de classe 'regular' definido entre as cotas 642 e $647 \mathrm{~m}$, associados à ocorrência de uma zona de fraturamento sub-horizontal intensa neste nível. A porção do maciço acima da cota 647 apresenta compartimentos de classe 'bom' intercalados com compartimentos de classes 'muito bom' e 'regular'.

A área de emboque do túnel encontra-se sobre um compartimento de classe 'regular' intercalada com um compartimento de classe 'bom', e na área de desemboque predominam 
compartimentos de classe 'muito bom' com intercalações de compartimentos de classe 'bom'. Na região da casa de força ocorre um compartimento delgado superficial de classe 'pobre', e em sub-superfície predomina um compartimento de classe 'regular'. Na região do conduto forçado ocorre um compartimento de classe 'bom' definido pela transição dos compartimentos de classes 'muito bom' e 'regular'. 


\section{CONCLUSÕES E RECOMENDAÇÕES}

Tendo em vista o recente aumento no número de projetos de pequenas centrais hidrelétricas (PCHs), e a importância das investigações geológico-geotécnicas para este tipo de obra, os estudos desenvolvidos na presente pesquisa contribuem para melhorar o estado de conhecimento do maciço rochoso na fase inicial do projeto.

A metodologia proposta para o estudo da compartimentação do maciço rochoso da $\mathrm{PCH}$ Morro Grande, baseada em dados já disponíveis e em dados obtidos em ensaios de baixo custo, visou à classificação do maciço rochoso a partir das sondagens rotativas, usando o sistem RMR, e a integração dos resultados em seções tipo, com o apoio da classificação parcial dos afloramentos rochosos.

Quanto ao desenvolvimento da pesquisa, destacam-se os seguintes aspectos:

- A obtenção de dados para o estudo do maciço rochoso da PCH Morro Grande foi realizada de três formas: através da coleta de dados superficiais, obtidos pela descrição de afloramentos de campo; de dados de sub-superfície, obtidos pela descrição de testemunhos de sondagens rotativas; e de ensaios de laboratório. O levantamento de dados foi baseado na metodologia de classificação escolhida para o estudo, o sistema RMR.

- A descrição dos afloramentos de campo permitiu um reconhecimento geral da área, com a descrição da litologia, do grau de alteração e das famílias de fraturas. A aplicação do sistema RMR nos afloramento foi feita de forma parcial, classificando apenas os parâmetros que podem refletir características do interior do maciço. As informações referentes ao fraturamento do maciço (espaçamento, persistência, abertura, preenchimento e orientação) são as que foram consideradas devido à continuidade espacial. 
- A classificação do maciço rochoso foi realizada sobre os testemunhos de sondagens rotativas. Para a descrição dos parâmetros solicitados pelo sistema RMR o boletim de descrição das sondagens foi reformulado, de modo a incluir campos para a representação dos parâmetros, e para a representação do resultado da classificação. Para os parâmetros que são representados por intervalos de valores, como é o caso do RQD/IQR, do espaçamento e da própria classificação RMR, foram utilizadas escalas de cores de forma a tornar visual a variação das classes. Esta forma de representação dos parâmetros, com a aplicação da classificação diretamente no boletim de sondagem, permitiu que a descrição pudesse ser feita de forma detalhada e que a classificação fosse feita de forma segmentada, baseada na variação dos parâmetros.

- A resistência da rocha intacta foi determinada através de ensaios de carga puntual, para os diferentes graus de alteração da rocha encontrados. O ensaio permitiu estabelecer de forma clara faixas de resistência da rocha para cada grau de alteração, permitindo a utilização do parâmetro 'grau de alteração' como parâmetro auxiliar na determinação da resistência ao longo da sondagem.

- A utilização do IQR no lugar do RQD permitiu uma melhor sensibilidade da classificação ao longo da sondagem, uma vez que considera trechos de fraturamento homogêneos, enquanto o RQD é baseado no comprimento da manobra, o que pode causar a homogeneização das informações. O cálculo do RQD utilizou sondagens em um diâmetro menor que o recomendado, visando o aproveitamento dos dados disponíveis, entretanto, recomenda-se que as sondagens sejam realizadas no diâmetro mínimo NW.

- A comparação da classificação RMR aplicada no modelo segmentado, que foi realizado com as alterações propostas, com a aplicada no modelo por comprimento de manobras, mostra que as alterações propostas neste estudo aumentam a sensibilidade da classificação às variações dos parâmetros. 
- A integração nas seções tipo da classificação RMR das sondagens com os dados de afloramento de campo, resultou na compartimentação final do maciço rochoso. A integração foi realizada comparando-se os pesos dos parâmetros classificados nos afloramentos com os classificados nas sondagens, prevalecendo o de valor mais baixo por caracterizar a condição menos favorável do maciço. Os pontos de campo e as sondagens foram relacionados de acordo com a proximidade entre eles.

- Os compartimentos definidos neste estudo correspondem às classes de maciço encontradas na classificação pelo Sistema RMR, sendo elas no total 5, 'muito bom', 'bom', 'regular', 'pobre' e 'muito pobre', das quais apenas a classe 'muito pobre' não foi encontrada.

- O cálculo de parâmetros geomecânicos não foi o objetivo principal desta pesquisa, tendo sido feito de forma expedita apenas para ilustrar as possibilidades da aplicação do sistema RMR. Para a aplicação destes parâmetros no projeto recomenda-se a realização de ensaios para a checagem dos resultados, salientando que os valores obtidos nos cálculos apresentados são estimados.

- O cálculo dos parâmetros geomecânicos para os compartimentos encontrados mostra certa discordância dos valores sugeridos pelo sistema RMR para cada classe, com exceção do tempo de auto-sustentação, preferindo-se a utilização dos valores sugeridos pela classificação.

A metodologia proposta permitiu elaborar a compartimentação do maciço rochoso nas áreas das estruturas da $\mathrm{PCH}$. O detalhamento obtido no estudo deve-se a elaboração da compartimentação baseada na classificação do maciço ao longo das sondagens, e não teria sido alcançado com a pré-compartimentação deste, e posterior classificação. 
Os principais resultados do estudo da compartimentação na PCH Morro Grande são:

- Entre as cotas 642 e $647 \mathrm{~m}$ ocorre uma zona de fraturamento sub-horizontal intenso, marcado por um espaçamento entre 5 e $15 \mathrm{~cm}$, onde a classificação pelo sistema RMR indica a classe 'regular' para o compartimento.

- O maciço de fundação da barragem encontra-se principalmente sobre um compartimento de classe 'bom', com a presença do compartimento de classe 'regular' acima da cota $642 \mathrm{~m}$, e classes 'regular' e 'pobre' nas porções superficiais, relacionadas ao avanço da capa de alteração.

- Na região do canal adutor, as escavações concentram-se sobre um compartimento de classe 'regular', e pode ocorrer uma cobertura de solos indiscriminados de espessura variável.

- Na região de emboque do túnel predominam compartimentos de classes 'regular' e 'bom'. Na primeira metade do túnel as escavações concentram-se sobre um compartimento de classe 'regular', passando na segunda metade para classes 'bom' e 'muito bom'. Na região de desemboque predominam compartimentos de classes 'regular' e 'muito bom'.

- O teto do túnel está em um compartimento de classe 'bom' com cerca de 2 metros de espessura, seguido logo acima pelo compartimento de classe 'regular' definido entre as cotas 642 e $647 \mathrm{~m}$.

- O maciço de fundação da casa de força encontra-se principalmente sobre um compartimento de classe 'regular', com a presença do compartimento de classe 'pobre' nas porções superficiais, relacionadas ao avanço da capa de alteração, e pode ocorrer uma cobertura de solos indiscriminados de espessura variável. 
- Os valores de vão máximo de seção e tempo médio de sustentação na região do túnel são de 15m e 6 anos para os compartimentos de classe 'muito bom', 10m e 7 a 17 meses para os de classe 'bom', e $5 \mathrm{~m}$ e 25 dias para os de classe 'regular'.

- Os valores de módulo de deformabilidade do compartimento de classe 'bom' na área da barragem é de 44 GPa, e de 18 GPa para o de classe 'regular'.

Destaca-se que os compartimentos representados com contato inferido apresentam caráter interpretativo, e as regiões onde as condições se apresentam mais críticas refletem os locais onde a realização de outras sondagens é mais necessária.

A principal dificuldade encontrada foi a pouca quantidade de dados, principalmente de sondagens rotativas, exigindo interpolações extensas entre um ponto de classificação e outro. Para este estudo, a classificação parcial dos afloramentos foi utilizada para auxiliar esta interpolação, entretanto, este método apresenta limitações, como o caráter superficial das informações. O ideal é que os projetos tenham mais sondagens rotativas, principalmente nas áreas de barramento e túnel, permitindo a elaboração de modelos mais detalhados e confiáveis do maciço rochoso.

A utilização conjunta da metodologia proposta com outros métodos de investigação do maciço rochoso, em especial os métodos geofísicos, apresenta grande potencial para melhorar a compartimentação do maciço, e é necessária em casos onde o número de sondagens é reduzido, e a distância entre elas é grande.

Destaca-se que esta pesquisa procurou desenvolver uma metodologia para o estudo da compartimentação de maciços rochosos, usando para isso as sondagens disponíveis na área, sendo que o resultado obtido tem caráter orientativo para a realização de investigações posteriores. 
Por fim conclui-se que os objetivos deste trabalho foram alcançados. O sistema RMR e as alterações propostas se mostraram uma ferramenta útil na elaboração da compartimentação de maciços rochosos, principalmente em maciços homogêneos, onde a pré-divisão de zonas com características uniformes é difícil. A metodologia proposta pode ser aplicada de forma rápida e a um custo baixo para os projetos de $\mathrm{PCH}$. 
ABGE (1983). Métodos para descrição quantitativa de descontinuidades em maciços rochosos. São Paulo. (tradução n. 12).

BARTON, N.; LIEN, R.; LUNDE, J. (1974). Engineering classification of rock masses for the design of tunnel support. Rock Mechanics. v. 6:4, p. 189-236.

BASU, A.; AYDIN, A. (2006). Predicting uniaxial compressive strength by point load test: significance of cone penetration. Technical note. Rock Mechanics and Rock Engineering. v.39:5, p. 483-490.

BROOK, N. (1985). The equivalent core diameter method of size and shape correction in point load testing. International Journal of Rock Mechanics Science and Geomechanics Abstract. v.22:2, p 61-70.

BIENIAWSKI, Z. T. (1973). Engineering classification of jointed rock masses. Trans South African Institut of Civil Engineering. v.15:12, p 335-344.

BIENIAWSKI, Z. T. (1975). The point load test in geotechnical practice. Engineering Geology. v.9, p. 1-11.

BIENIAWSKI, Z. T. (1976). Rock mass classification in rock engineering. In: SYMPOSIUM ON EXPLORATION FOR ROCK ENGINEERING, 1976, Johannesburg. Proceedings. p. 97-107.

BIENIAWSKI, Z. T.; ORR, C. M. (1976). Rapid system appraisal for dam foundations by the geomechanics classification. In: CONGRESS ON LARGE DAMS, 12., 1976, Cidade do México. ICOLD. p. 483-501. 
BIENIAWSKI, Z. T. (1979). The geomechanics classification in rock engineering applications. In: INTERNATIONAL CONGRESS ON ROCK MECHANICS, 4., 1979, Montreux. Proceedings. ISRM, v.2, p 41-48.

BIENIAWSKI, Z. T. (1988). The rock mass rating (RMR) system (geomechanics classification) in engineering practice. KIRKALDIE, L. Rock classification systems for engineering purposes, Philadelphia. ASTM STP 984. p.17-34.

BIENIAWSKI, Z. T. (1989). Engineering rock mass classification - A complete manual for engineers and geologists in mining, civil and petroleum engineering. Nova York, Wiley Interscience. 251p.

BRASIL (1998). Resolução n 395, de 04 de dezembro de 1998 - Estabelece os procedimentos gerais para registro e aprovação de estudos de viabilidade e projeto básico de empreendimentos de geração hidrelétrica, assim como da autorização para exploração de centrais hidrelétricas até $30 \mathrm{MW}$ e dá outras providências.

CAMARGO, F. P.; LEITE, C. A. G.; BERTIN NETO, S.; MALDONADO, F.; CRUZ, P.T. (1978). Development of conceptual geomechanical models for foudations of concrete dam - approach applied to three projects. In: INTERNATIONAL SYMPOSIUM ON ROCK MECHANICS RELATED TO DAM FOUNDATION, 1978, Rio de Janeiro. Proceedings. ISRM/ABMS, Tema 2, p 57-78.

CARVALHO, R. M.; PAYOLLA B. L.; REZENDE, M. A. (1987). Compartimentação geomecânica das fundações das estruturas de concreto da UHE de Babaquara, Rio Xingu. In: CONGRESSO BRASILEIRO DE GEOLOGIA DE ENGENHARIA, 5., 1987. Anais. São Paulo. ABGE. Vol. 1, p 227- 240.

CBGB, (1983). Diretrizes para a inspeção e avaliação de segurança de barragens em operação. Rio de Janeiro, 26p.

CRUZ, P. T. (1996). 100 Barragens Brasileiras: Casos Históricos, Materiais de Construção, Projeto. São Paulo. Oficina de Textos. 648p. 
DEERE, D. U.; DEERE, D. W. (1988). The rock quality designation (RQD) index in practice. KIRKALDIE, L. Rock classification systems for engineering purposes, Philadelphia. ASTM STP 984. p.91-101.

DOBEREINER, L.; CAMARGO, F. P.; E JÁCOMO, A. A. C. (1987). Caracterização geomecânica do maciço rochoso de fundação da UHE Cachoeira Porteira. In: CONGRESSO BRASILEIRO DE GEOLOGIA DE ENGENHARIA, 5., 1987. Anais. São Paulo. ABGE. Vol. 1, p 181- 195.

EL-NAQA, A. (1994). Rock mass characterization of Wadi Mujib dam site, central Jordan. Engineering Geology. v. 38 p. 81-93.

FIGUEIREDO, A. L. C. (1996). Caracterização geomecânica do maciço de fundação da UHE Tijuco Alto (Rio Ribeira-SP/PR). Dissertação (Mestrado) - Escola de Engenharia de São Carlos, Universidade de São Paulo, São Carlos.

GABRIELSEN, R. H. (1990). Characteristics of joints and faults. BARTON, N. e STEPHANSSON, O. Rock Joints; INTERNATIONAL SYMPOSIUM ON ROCK JOINTS, Proceedings. Loen, Norway. Balkema. p. 11-19.

GUIDICINI, G.; SANTOS OLIVEIRA, A. M.; PIRES DE CAMARGO, F.; KAJI, N. (1972a). Um método de classificação geotécnica preliminar de meios rochosos. In: SEMANA PAULISTA DE GEOLOGIA APLICADA, 4., Anais. São Paulo. p 275 - 282.

GUIDICINI, G.; NIEBLE, C.M.; CORNIDES, A.T. (1972b). Análise do método de compressão puntiforme em fragmentos irregulares, na caracterização geotécnica preliminar de rochas. In: SEMANA PAULISTA DE GEOLOGIA APLICADA, 4., Anais. São Paulo. p 237264.

GEHRING, J.G.; (1987). Aspectos Atuais na Avaliação da Segurança de Barragens em Operação. Dissertação (Mestrado) - Universidade de São Paulo, São Paulo, $249 p$. 
HOEK, E. (2000). Pratical Rock Engineereing. 2007 Edition. Disponível em: <http://www.rocscience.com/hoek/PracticalRockEngineering.asp> Acesso em: 01/03/2009.

IPT. (1983). Uma proposta sistemática de estudos geolóico-geotécnicos para projetos de túneis. Relatório 19 173. São Paulo. 100p.

ISRM (1978). Suggested methods for the quantitative description of discontinuities in rock mechanics. International Journal of Rock Mechanics Science and Geomechanics. Abstract. v.15 p. 319-368.

ISRM (1985). Suggested methods for determining point load strength. International Journal of Rock Mechanics Science and Geomechanics. Abstract. v.22:2 p. 5160 .

KAHARMAN, S. (2001). Evaluation of simple methods for assessing the uniaxial compressive strength of rock. International Journal of Rock Mechanics \& Mining Sciences. v. 38 p. 981-994.

KIRKALDIE, L. (1988). Rock classification systems for engineering purposes, Philadelphia. ASTM STP 984.

KIRSTEN, H. A. D. (1988). Discussion. In: KIRKALDIE, L. Rock classification systems for engineering purposes, Philadelphia. ASTM STP 984.

KOCBAY, A.; KILIC, R. (2006). Engineering geological assessment of the Obruk dam site (Corum, Turkey). Engineering Geology. v. 87 p. 141-148.

LASHKARIPOUR, G. R.; GHAFOORI, M. (2002). The engineering geology of the Tabarak Abad dam. Engineering Geology. v. 66 p. 233-239. 
LEINZ, V. (1949). Contribuição à geologia dos derrames basálticos do sul do Brasil. Boletim da Faculdade de Filosofia, Ciências e Letras. USP. 3:5 61p.

MAGALHÃES, F. S.; CELLA, P. R. C. (1998). Estruturas dos maciços rochosos. OLIVEIRA, A.M.S.; BRITO, S. N. A.. Geologia de Engenharia. São Paulo. ABGE. Oficina de Texto. p. 39-55.

MALAFAIA, A. L. (2007). Estudo de sistemas de classificação dos maciços rochosos da UHE Batalha. Dissertação (Mestrado) - COPPE/UFRJ. Rio de Janeiro.

MARIMON, M. P. C.; AYALA, L.; MOREIRA, M. L. O. (1982). Formação Serra Geral no Sul do Brasil, rochas básicas e ácidas: sua distribuição, petrografia e litoquímica. In: Congresso Brasileiro de Geologia, 32, 1982, Salvador. Anais. Salvador: SBG. v. 2 p. 402-414.

MESQUITA, J. B. (2008). Maciços rochosos de projetos hidrelétricos: metodologia de classificação. Tese (Doutorado) - UNESP. Rio Claro.

MILANI E.J.; FRANÇA A.B.; SCHNEIDER R.L. (1994). Bacia do Paraná. Boletim de Geociências Petrobrás v. 8:1 p. 69-82.

MILANI E.J.; RAMOS V.A. (1998). Orogenias paleozóicas no domínio sulocidental do Gondwana e os ciclos de subsidência da Bacia do Paraná. Revista Brasileira de Geociências v. 28:4 p. 473-484.

MONTICELI, J. J. (1983). Influência da compartimentação geológico-geotécnica de maciços rochosos no projeto de fundações de barragens - fase de viabilidade. Dissertação (Mestrado) - Escola de Engenharia de São Carlos, Universidade de São Paulo, São Carlos. 149p.

NIEBLE C. M.; FRANCIS F. O. (1976). Classificação de maciços rochosos. In: CONGRESSO BRASILEIRO DE GEOLOGIA DE ENGENHARIA, 1., Anais. Rio de Janeiro. v. 2. p. 378-394. 
OJIMA, L. M. (1982). Metodologia de classificação de maciços rochosos aplicável a túneis. São Paulo. ABGE. Síntese de tese. 100p.

ÖZSAM, A.; AKIM, M. (2002). Engineering geological assessment of the proposed Urus dam, Turkey. Engineering Geology. v. 66 p. 271-281.

PAULON, J.; MARTINS NETO, J. M. (2000). Pequenas centrais hidrelétricas Histórico e perspectivas. In: SIMPÓSIO BRASILEIRO SOBRE PEQUENAS E MÉDIAS CENTRAIS HIDRELÉTRICAS, 2., Anais. Canela, Rio Grande do Sul. p. 267-280.

PINCUS, H. J. (1988). Opening Remarks. KIRKALDIE, L. Rock classification systems for engineering purposes, Philadelphia. ASTM STP 984.

SEN Z.; SADAGAH B. H. (2003). Modified rock mass classification system by continuous rating. Engineering Geology. v. 67 p. 269-280.

SERAFIM, J. L.; PEREIRA, J. P. (1983). Considerations of the geomechanics classification of Bieniawski. In: INTERNATIONAL SYMPOSIUM ON ENGINEERING GEOLOGY AND UNDERGROUND CONSTRUCTION. Lisboa. Proceedings. v. 1: 2, p 33-42.

SERRA JUNIOR, E.; OJIMA, L. M. (1998). Classificação de maciços rochosos OLIVEIRA, A.M.S.; BRITO, S. N. A.. Geologia de Engenharia. São Paulo. ABGE. Oficina de Texto. p. 15-38.

SCHNEIDER R.L.; MUHLMANN H.; TOMMASI E.; MEDEIROS R.A.; DAEMON R.F.; NOGUEIRA A.A. (1974). Revisão estratigráfica da Bacia do Paraná. In: CONGRESSO BRASILEIRO DE GEOLOGIA, 28, Porto Alegre. Anais. SBG. v. 1 p. 41-65.

SCHOBBENHAUS C.; ALMEIDA CAMPOS D.; DERZE G.R.; ASMUS H.E. (1984). Geologia do Brasil. Brasília, DNPM, 501p. 
SOUZA JUNIOR, N. N. (1986). Feições lito-estruturais de interesse geológico e geotécnico em maciços basálticos. Dissertação (mestrado) - Escola de Engenharia de São Carlos, Universidade de São Paulo, São Carlos. 183p.

TERZAGHI, K. (1946). Rock Defects and Loads on Tunnel Supports. PROCTOR R.V. e WHITE T.L., Rock Tunnelling with Steel Supports, Commercial Shearing and Stamping Co., Youngstown, Ohio.

VAZ, L. F. (1996). Grau de alteração de rochas. In: CONGRESSO BRASILEIRO DE GEOLOGIA DE ENGENHARIA, 8., Anais. ABGE. Rio de Janeiro. v. 1 p. 71-80.

ZALÁN P.V.; WOLF S.; ASTOLFI M.A.M.; VIERA .S.; CONCIEÇÃO J.C.J.; NETO E.V.S.; MARQUES A. (1987). Tectônica e Sedimentação da Bacia do Paraná. SIMPÓSIO SUL-BRASILEIRO DE GEOLOGIA, 3., Anais. v.1 p.441-473. 
ANEXO A

(Resultado dos ensaios de carga puntual) 


\begin{tabular}{|c|c|c|c|c|c|c|c|c|}
\hline SR & Amostra & Alteração & $\begin{array}{l}\text { Diâmetro } \\
(\mathrm{mm})\end{array}$ & $\begin{array}{c}\text { p - Pressão } \\
\text { manômetro } \\
(\text { Kgf/cm2) }\end{array}$ & $\begin{array}{l}\text { Q - Carga } \\
\text { calculada } \\
\text { (KN) }\end{array}$ & $\begin{array}{l}\text { Is (Índice } \\
\text { de Carga } \\
\text { Puntual) }\end{array}$ & $\begin{array}{l}\mathrm{F} \text { (fator de } \\
\text { correção) }\end{array}$ & $\begin{array}{l}\text { Is (50) } \\
\text { (MPa) }\end{array}$ \\
\hline \multirow{6}{*}{ SR1 } & 1 & A1 & 54,3 & 90 & 29,3 & 9,94 & 1,038 & 10,31 \\
\hline & $2 A$ & A1 & 42,1 & 85 & 27,7 & 15,61 & 0,926 & 14,45 \\
\hline & $2 B$ & A1 & 42,1 & 80 & 26,0 & 14,68 & 0,926 & 13,59 \\
\hline & $2 C$ & A1 & 42,1 & 76 & 24,7 & 13,94 & 0,926 & 12,90 \\
\hline & $3 \mathrm{~A}$ & $\mathrm{~A} 1 / \mathrm{A} 2$ & 42,1 & 61 & 19,8 & 11,17 & 0,926 & 10,34 \\
\hline & $3 B$ & $\mathrm{~A} 1 / \mathrm{A} 2$ & 42,1 & 56 & 18,2 & 10,24 & 0,926 & 9,48 \\
\hline \multirow{16}{*}{ SR2 } & 4 & $\mathrm{~A} 1 / \mathrm{A} 2$ & 54,3 & 95 & 30,9 & 10,49 & 1,038 & 10,89 \\
\hline & $5 \mathrm{~A}$ & $\mathrm{~A} 1 / \mathrm{A} 2$ & 42,1 & 66 & 21,4 & 12,09 & 0,926 & 11,19 \\
\hline & $5 B$ & $\mathrm{~A} 1 / \mathrm{A} 2$ & 42,1 & 64 & 20,8 & 11,72 & 0,926 & 10,85 \\
\hline & $5 C$ & $\mathrm{~A} 1 / \mathrm{A} 2$ & 42,1 & 63 & 20,4 & 11,54 & 0,926 & 10,68 \\
\hline & $6 \mathrm{~A}$ & A2 & 42,1 & - & - & - & 0,926 & - \\
\hline & $6 B$ & A2 & 42,1 & 47 & 15,2 & 8,58 & 0,926 & 7,94 \\
\hline & $7 A$ & A2 & 42,1 & - & - & - & 0,926 & - \\
\hline & $7 B$ & A2 & 42,1 & 38 & 12,2 & 6,91 & 0,926 & 6,40 \\
\hline & $8 \mathrm{~A}$ & A2 & 42,1 & - & - & - & 0,926 & - \\
\hline & $8 B$ & A2 & 42,1 & 43 & 13,9 & 7,84 & 0,926 & 7,25 \\
\hline & $8 C$ & $\mathrm{~A} 2$ & 42,1 & 32 & 10,3 & 5,80 & 0,926 & 5,37 \\
\hline & $9 \mathrm{~A}$ & $\mathrm{~A} 1 / \mathrm{A} 2$ & 42,1 & 66 & 21,4 & 12,09 & 0,926 & 11,19 \\
\hline & $9 B$ & A1/A2 & 42,1 & 69 & 22,4 & 12,65 & 0,926 & 11,71 \\
\hline & $10 \mathrm{~A}$ & $\mathrm{~A} 1 / \mathrm{A} 2$ & 42,1 & 65 & 21,1 & 11,91 & 0,926 & 11,02 \\
\hline & $10 \mathrm{~B}$ & $\mathrm{~A} 1 / \mathrm{A} 2$ & 42,1 & 65 & 21,1 & 11,91 & 0,926 & 11,02 \\
\hline & $10 \mathrm{C}$ & $\mathrm{A} 1 / \mathrm{A} 2$ & 42,1 & 74 & 24,1 & 13,57 & 0,926 & 12,56 \\
\hline \multirow{5}{*}{ SR3 } & 11 & $\mathrm{~A} 1 / \mathrm{A} 2$ & 42 & 68 & 22,1 & 12,52 & 0,925 & 11,58 \\
\hline & $12 \mathrm{~A}$ & $\mathrm{~A} 1 / \mathrm{A} 2$ & 42,1 & 66 & 21,4 & 12,09 & 0,926 & 11,19 \\
\hline & $12 \mathrm{~B}$ & $\mathrm{~A} 1 / \mathrm{A} 2$ & 42,1 & 73 & 23,7 & 13,39 & 0,926 & 12,39 \\
\hline & 13 & $\mathrm{~A} 1 / \mathrm{A} 2$ & 42,1 & 66 & 21,4 & 12,09 & 0,926 & 11,19 \\
\hline & 14 & A3 & 41,7 & 4 & 1,1 & 0,63 & 0,922 & 0,58 \\
\hline \multirow{7}{*}{ SR4 } & 15 & A2 & 41,9 & 53 & 17,2 & 9,78 & 0,924 & 9,03 \\
\hline & $16 \mathrm{~A}$ & A1/A2 & 41,9 & 44 & 14,2 & 8,10 & 0,924 & 7,48 \\
\hline & $16 \mathrm{~B}$ & $\mathrm{~A} 1 / \mathrm{A} 2$ & 41,9 & 60 & 19,5 & 11,09 & 0,924 & 10,24 \\
\hline & $17 \mathrm{~A}$ & $\mathrm{~A} 1 / \mathrm{A} 2$ & 41,9 & 63 & 20,4 & 11,65 & 0,924 & 10,76 \\
\hline & $17 \mathrm{~B}$ & $\mathrm{~A} 1 / \mathrm{A} 2$ & 41,9 & 66 & 21,4 & 12,21 & 0,924 & 11,27 \\
\hline & $18 \mathrm{~A}$ & $A 1 / A 2$ & 42 & 52 & 16,8 & 9,55 & 0,925 & 8,83 \\
\hline & $18 \mathrm{~B}$ & A1/A2 & 42 & 65 & 21,1 & 11,96 & 0,925 & 11,06 \\
\hline
\end{tabular}




\begin{tabular}{|c|c|c|c|c|c|c|c|c|}
\hline SR & Amostra & Alteração & $\begin{array}{l}\text { Diâmetro } \\
(\mathrm{mm})\end{array}$ & $\begin{array}{c}p-\text { Pressão } \\
\text { manômetro } \\
(\text { Kgf/cm2) }\end{array}$ & $\begin{array}{c}\text { Q - Carga } \\
\text { calculada } \\
(\mathrm{KN})\end{array}$ & $\begin{array}{l}\text { Is (Índice } \\
\text { de Carga } \\
\text { Puntual) }\end{array}$ & $\begin{array}{l}\mathrm{F} \text { (fator de } \\
\text { correção) }\end{array}$ & $\begin{array}{l}\text { Is (50) } \\
\text { (MPa) }\end{array}$ \\
\hline \multirow{16}{*}{ SR2 } & $22 \mathrm{~A}$ & $\mathrm{~A} 2$ & 42,1 & 46 & 14,9 & 8,39 & 0,926 & 7,77 \\
\hline & 22B & A2 & 42,1 & 23 & 7,3 & 4,13 & 0,926 & 3,83 \\
\hline & 23 & $\mathrm{~A} 2$ & 42,1 & 47 & 15,2 & 8,58 & 0,926 & 7,94 \\
\hline & $24 \mathrm{~A}$ & $\mathrm{~A} 2$ & 42,1 & 41 & 13,2 & 7,47 & 0,926 & 6,91 \\
\hline & $24 B$ & $\mathrm{~A} 2$ & 42,1 & 27 & 8,6 & 4,87 & 0,926 & 4,51 \\
\hline & 25 & A2 & 42,1 & 26 & 8,3 & 4,69 & 0,926 & 4,34 \\
\hline & 26 & A2 & 42,1 & 35 & 11,3 & 6,36 & 0,926 & 5,88 \\
\hline & 27 & $\mathrm{~A} 2$ & 42,1 & 31 & 10,0 & 5,62 & 0,926 & 5,20 \\
\hline & $28 \mathrm{~A}$ & $\mathrm{~A} 2$ & 42,1 & - & - & - & 0,926 & - \\
\hline & $28 \mathrm{~B}$ & $A 2$ & 42,1 & 38 & 12,2 & 6,91 & 0,926 & 6,40 \\
\hline & 29 & A2 & 42,1 & 34 & 10,9 & 6,17 & 0,926 & 5,71 \\
\hline & $30 \mathrm{~A}$ & $\mathrm{~A} 2$ & 42,1 & 49 & 15,9 & 8,95 & 0,926 & 8,28 \\
\hline & $30 B$ & A2 & 42,1 & 41 & 13,2 & 7,47 & 0,926 & 6,91 \\
\hline & $31 \mathrm{~A}$ & A2 & 42,1 & 41 & 13,2 & 7,47 & 0,926 & 6,91 \\
\hline & $31 \mathrm{~B}$ & $\mathrm{~A} 2$ & 42,1 & 35 & 11,3 & 6,36 & 0,926 & 5,88 \\
\hline & 32 & A2 & 42,1 & 45 & 14,5 & 8,21 & 0,926 & 7,59 \\
\hline \multirow{5}{*}{ SR4 } & 33 & A3 & 41,7 & 8 & 2,4 & 1,38 & 0,922 & 1,28 \\
\hline & 34 & A3 & 41,7 & 5 & 1,4 & 0,82 & 0,922 & 0,75 \\
\hline & 35 & $\mathrm{~A} 2$ & 41,9 & 51 & 16,5 & 9,41 & 0,924 & 8,69 \\
\hline & $36 \mathrm{~A}$ & A2 & 41,9 & 55 & 17,8 & 10,15 & 0,924 & 9,38 \\
\hline & $36 B$ & A2 & 41,9 & 50 & 16,2 & 9,22 & 0,924 & 8,51 \\
\hline
\end{tabular}

Para o ensaio diametral De é igual a D

$$
\begin{aligned}
& Q=(0,328 \times p)-0,2158 \quad(\mathrm{KN}) \\
& I s=Q / D_{e}^{2} \times 1000 \quad(\mathrm{MPa}) \\
& F=\left(D_{e} / 50\right)^{0,45} \\
& I s_{(50)}=F \times I s \quad(\mathrm{MPa})
\end{aligned}
$$




\begin{tabular}{|c|c|}
\hline $\begin{array}{c}\text { Amostra } \\
\text { A1 }\end{array}$ & Is (50) \\
\hline $16 \mathrm{~A}$ & 7,48 \\
\hline $18 \mathrm{~A}$ & 8,83 \\
\hline $3 B$ & 9,48 \\
\hline $16 \mathrm{~B}$ & 10,24 \\
\hline 1 & 10,31 \\
\hline $3 A$ & 10,34 \\
\hline $5 C$ & 10,68 \\
\hline $17 \mathrm{~A}$ & 10,76 \\
\hline $5 B$ & 10,85 \\
\hline 4 & 10,89 \\
\hline $10 \mathrm{~A}$ & 11,02 \\
\hline $10 B$ & 11,02 \\
\hline $18 \mathrm{~B}$ & 11,06 \\
\hline $5 A$ & 11,19 \\
\hline $9 A$ & 11,19 \\
\hline $12 \mathrm{~A}$ & 11,19 \\
\hline 13 & 11,19 \\
\hline $17 \mathrm{~B}$ & 11,27 \\
\hline 11 & 11,58 \\
\hline $9 B$ & 11,71 \\
\hline $12 \mathrm{~B}$ & 12,39 \\
\hline $10 \mathrm{C}$ & 12,56 \\
\hline $2 C$ & 12,90 \\
\hline $2 B$ & 13,59 \\
\hline $2 A$ & 14,45 \\
\hline
\end{tabular}

\begin{tabular}{|c|c|c|c|}
\hline $\begin{array}{c}\text { Amostra } \\
\text { A2 }\end{array}$ & Is (50) & $\begin{array}{c}\text { Amostra } \\
\mathrm{A} 3\end{array}$ & Is (50) \\
\hline $22 \mathrm{~B}$ & 3,83 & 14 & 0,58 \\
\hline 25 & 4,34 & 33 & 1,28 \\
\hline $24 \mathrm{~B}$ & 4,51 & 34 & 0,75 \\
\hline
\end{tabular}

MÉDIA

(Excluindo os dois valores maiores e menores)

$\begin{array}{cc}\text { A1 } & 11,13 \\ \text { A2 } & 6,74 \\ \text { A3 } & 0,87\end{array}$


ANEXO B

(Planilhas do cálculo da ação da água subterrânea) 
SR1

solo $=1,4 \mathrm{~m}$

$N A=634 \mathrm{~m}$ $\rho_{\text {água }}=1$

$\rho_{\text {solo }}=1,8$

$\rho_{\text {rocha }}=2,7$

\begin{tabular}{|c|c|c|c|c|c|c} 
Profundidade & Cota & $\begin{array}{c}\text { Espessura } \\
\text { de solo }\end{array}$ & $\begin{array}{c}\text { Espessura } \\
\text { de rocha }\end{array}$ & $\begin{array}{c}\text { Coluna } \\
\text { d'água }\end{array}$ & $\begin{array}{c}\text { Págua } \\
\text { (Psolo+Procha) }\end{array}$ & NOTA \\
\hline 2 & 638 & 1,4 & 0,6 & 0 & 0,00 & 15 \\
\hline 4 & 636 & 1,4 & 2,6 & 0 & 0,00 & 15 \\
\hline 6 & 634 & 1,4 & 4,6 & 0 & 0,00 & 15 \\
\hline 7 & 633 & 1,4 & 5,6 & 1 & 0,06 & 10 \\
\hline 8 & 632 & 1,4 & 6,6 & 2 & 0,10 & 10 \\
\hline 9 & 631 & 1,4 & 7,6 & 3 & 0,13 & 7 \\
\hline 10 & 630 & 1,4 & 8,6 & 4 & 0,16 & 7 \\
\hline 11 & 629 & 1,4 & 9,6 & 5 & 0,18 & 7 \\
\hline 12 & 628 & 1,4 & 10,6 & 6 & 0,19 & 7 \\
\hline 13 & 627 & 1,4 & 11,6 & 7 & 0,21 & 4 \\
\hline
\end{tabular}

SR2

solo $=0,0 \mathrm{~m}$

$\rho_{\text {água }}=1$

$\mathrm{NA}=630 \mathrm{~m}$

$$
\rho_{\text {solo }}=1,8
$$

$\rho_{\text {rocha }}=2,7$

\begin{tabular}{c|c|c|c|c|c|c} 
Profundidade & Cota & $\begin{array}{c}\text { Espessura } \\
\text { de solo }\end{array}$ & $\begin{array}{c}\text { Espessura } \\
\text { de rocha }\end{array}$ & $\begin{array}{c}\text { Coluna } \\
\text { d'água }\end{array}$ & $\begin{array}{c}\text { Págua } \\
\text { (Psolo+Procha) }\end{array}$ & NOTA \\
\hline 10 & 660 & 0 & 10 & 0 & 0,00 & 15 \\
\hline 20 & 650 & 0 & 20 & 0 & 0,00 & 15 \\
\hline 30 & 640 & 0 & 30 & 0 & 0,00 & 15 \\
\hline 40 & 630 & 0 & 40 & 0 & 0,00 & 15 \\
\hline 41 & 629 & 0 & 41 & 1 & 0,01 & 10 \\
\hline
\end{tabular}

SR3

solo $=7,7 \mathrm{~m}$

$\rho_{\text {água }}=1$

$\mathrm{NA}=$ abaixo de $627 \mathrm{~m}$

$\rho_{\text {solo }}=1,8$

$\rho_{\text {rocha }}=2,7$

\begin{tabular}{c|c|c|c|c|c|c} 
Profundidade & Cota & $\begin{array}{c}\text { Espessura } \\
\text { de solo }\end{array}$ & $\begin{array}{c}\text { Espessura } \\
\text { de rocha }\end{array}$ & $\begin{array}{c}\text { Coluna } \\
\text { d'água }\end{array}$ & $\begin{array}{c}\text { Págua } \\
\text { (Psolo+Procha) }\end{array}$ & NOTA \\
\hline 5 & 645 & 5 & 0 & 0 & 0,00 & 15 \\
\hline 10 & 640 & 7,7 & 2,3 & 0 & 0,00 & 15 \\
\hline 15 & 635 & 7,7 & 7,3 & 0 & 0,00 & 15 \\
\hline 20 & 630 & 7,7 & 12,3 & 0 & 0,00 & 15 \\
\hline 23 & 627 & 7,7 & 15,3 & 0 & 0,00 & 15 \\
\end{tabular}




\begin{tabular}{|c|c|c|c|c|c|c|}
\hline \multicolumn{2}{|l|}{$\begin{array}{l}\text { SR4 } \\
\text { solo }=2,5 \mathrm{~m} \\
\mathrm{NA}=6,9 \mathrm{~m}\end{array}$} & \multicolumn{2}{|c|}{$\begin{array}{l}\rho_{\text {água }}=1 \\
\rho_{\text {solo }}=1,8\end{array}$} & & & \\
\hline Profundidade & Cota & $\begin{array}{c}\text { Espessura } \\
\text { de solo }\end{array}$ & $\begin{array}{l}\text { Espessura } \\
\text { de rocha }\end{array}$ & $\begin{array}{l}\text { Coluna } \\
\text { d'água }\end{array}$ & $\frac{\text { Págua }}{\text { (Psolo+Procha) }}$ & NOTA \\
\hline 1 & 591 & 1 & 0 & 0 & 0,00 & 15 \\
\hline 2 & 590 & 2 & 0 & 0 & 0,00 & 15 \\
\hline 3 & 589 & 2,5 & 0,5 & 0 & 0,00 & 15 \\
\hline 4 & 588 & 2,5 & 1,5 & 0 & 0,00 & 15 \\
\hline 5 & 587 & 2,5 & 2,5 & 0 & 0,00 & 15 \\
\hline 6 & 586 & 2,5 & 3,5 & 0 & 0,00 & 15 \\
\hline 7 & 585 & 2,5 & 4,5 & 0,1 & 0,01 & 10 \\
\hline 8 & 584 & 2,5 & 5,5 & 1,1 & 0,06 & 10 \\
\hline 9 & 583 & 2,5 & 6,5 & 2,1 & 0,10 & 10 \\
\hline 10 & 582 & 2,5 & 7,5 & 3,1 & 0,13 & 7 \\
\hline 11 & 581 & 2,5 & 8,5 & 4,1 & 0,15 & 7 \\
\hline 12 & 580 & 2,5 & 9,5 & 5,1 & 0,17 & 7 \\
\hline 13 & 579 & 2,5 & 10,5 & 6,1 & 0,19 & 7 \\
\hline 14 & 578 & 2,5 & 11,5 & 7,1 & 0,20 & 7 \\
\hline 15 & 577 & 2,5 & 12,5 & 8,1 & 0,21 & 4 \\
\hline 16 & 576 & 2,5 & 13,5 & 9,1 & 0,22 & 4 \\
\hline 17 & 575 & 2,5 & 14,5 & 10,1 & 0,23 & 4 \\
\hline 18 & 574 & 2,5 & 15,5 & 11,1 & 0,24 & 4 \\
\hline 19 & 573 & 2,5 & 16,5 & 12,1 & 0,25 & 4 \\
\hline 20 & 572 & 2,5 & 17,5 & 13,1 & 0,25 & 4 \\
\hline 21 & 571 & 2,5 & 18,5 & 14,1 & 0,26 & 4 \\
\hline 22 & 570 & 2,5 & 19,5 & 15,1 & 0,26 & 4 \\
\hline 23 & 569 & 2,5 & 20,5 & 16,1 & 0,27 & 4 \\
\hline
\end{tabular}


ANEXO C

(Planilhas de aplicação da classificação) 


\begin{tabular}{|c|c|c|c|c|c|c|c|c|c|c|c|}
\hline \multicolumn{12}{|c|}{ SR1 } \\
\hline 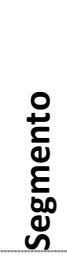 & 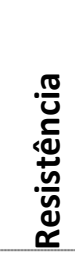 & $\underset{\sim}{\text { ه্ }}$ & 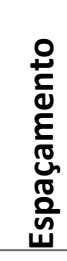 & 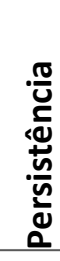 & $\begin{array}{l}\frac{\pi}{2} \\
\frac{1}{2} \\
\frac{1}{\alpha} \\
\frac{0}{\alpha}\end{array}$ & 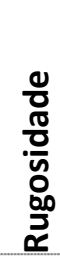 & 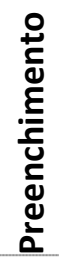 & 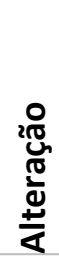 & 丞 & 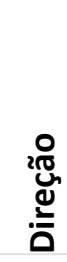 & $\sum_{\tilde{\alpha}}^{\mathscr{q}}$ \\
\hline 1 & 1 & 5 & 5 & 2 & 1 & 3 & 6 & 1 & 15 & -7 & 32 \\
\hline 2 & 12 & 5 & 5 & 2 & 1 & 3 & 6 & 1 & 15 & -7 & 43 \\
\hline 3 & 15 & 17 & 8 & 2 & 4 & 3 & 6 & 5 & 15 & -7 & 68 \\
\hline 4 & 15 & 17 & 8 & 2 & 5 & 3 & 6 & 5 & 15 & -7 & 69 \\
\hline 5 & 15 & 17 & 8 & 2 & 5 & 3 & 6 & 5 & 15 & -7 & 69 \\
\hline 6 & 15 & 20 & 15 & 2 & 5 & 3 & 6 & 5 & 15 & -7 & 79 \\
\hline 7 & 15 & 20 & 15 & 2 & 5 & 3 & 6 & 5 & 10 & -7 & 74 \\
\hline 8 & 15 & 20 & 20 & 2 & 5 & 3 & 6 & 5 & 7 & -7 & 76 \\
\hline 9 & 15 & 20 & 15 & 2 & 5 & 3 & 6 & 5 & 7 & -7 & 71 \\
\hline 10 & 15 & 20 & 15 & 2 & 5 & 3 & 6 & 5 & 4 & -7 & 68 \\
\hline
\end{tabular}

\begin{tabular}{|c|c|c|c|c|c|c|c|c|c|c|c|}
\hline \multicolumn{10}{|c|}{ SR3 } \\
\hline $\mathbf{1}$ & 12 & 5 & 5 & 2 & 1 & 5 & 2 & 3 & 15 & -5 & $\mathbf{4 5}$ \\
\hline $\mathbf{2}$ & 15 & 20 & 10 & 2 & 5 & 5 & 6 & 5 & 15 & -5 & $\mathbf{7 8}$ \\
\hline $\mathbf{3}$ & 15 & 20 & 15 & 2 & 5 & 5 & 6 & 5 & 15 & -5 & $\mathbf{8 3}$ \\
\hline $\mathbf{4}$ & 15 & 20 & 15 & 2 & 5 & 5 & 6 & 5 & 15 & -5 & $\mathbf{8 3}$ \\
\hline $\mathbf{5}$ & 15 & 17 & 10 & 2 & 5 & 5 & 6 & 5 & 15 & -5 & $\mathbf{7 5}$ \\
\hline $\mathbf{6}$ & 15 & 20 & 15 & 2 & 5 & 5 & 6 & 5 & 15 & -5 & $\mathbf{8 3}$ \\
\hline $\mathbf{7}$ & 15 & 20 & 15 & 2 & 5 & 5 & 6 & 5 & 15 & -5 & $\mathbf{8 3}$ \\
\hline $\mathbf{8}$ & 15 & 17 & 10 & 2 & 5 & 5 & 6 & 5 & 15 & -5 & $\mathbf{7 5}$ \\
\hline $\mathbf{9}$ & 15 & 20 & 15 & 2 & 5 & 5 & 6 & 5 & 15 & -5 & $\mathbf{8 3}$ \\
\hline
\end{tabular}

\begin{tabular}{|c|c|c|c|c|c|c|c|c|c|c|c|}
\hline $\mathbf{1 0}$ & \multicolumn{10}{|c|}{ SR4 } \\
\hline $\mathbf{1}$ & 1 & 5 & 5 & 2 & 1 & 1 & 2 & 1 & 15 & -7 & $\mathbf{2 6}$ \\
\hline $\mathbf{2}$ & 1 & 5 & 5 & 2 & 4 & 1 & 2 & 1 & 15 & -7 & $\mathbf{2 9}$ \\
\hline $\mathbf{3}$ & 1 & 5 & 5 & 2 & 4 & 1 & 2 & 1 & 15 & -7 & $\mathbf{2 9}$ \\
\hline $\mathbf{4}$ & 12 & 5 & 8 & 2 & 4 & 1 & 2 & 1 & 15 & -7 & $\mathbf{4 3}$ \\
\hline $\mathbf{5}$ & 12 & 5 & 8 & 2 & 4 & 1 & 2 & 3 & 15 & -7 & $\mathbf{4 5}$ \\
\hline $\mathbf{6}$ & 12 & 13 & 8 & 2 & 4 & 1 & 2 & 3 & 15 & -7 & $\mathbf{5 3}$ \\
\hline $\mathbf{7}$ & 15 & 13 & 10 & 2 & 4 & 1 & 2 & 3 & 15 & -7 & $\mathbf{5 8}$ \\
\hline $\mathbf{8}$ & 15 & 13 & 8 & 2 & 4 & 1 & 2 & 3 & 15 & -7 & $\mathbf{5 6}$ \\
\hline $\mathbf{9}$ & 15 & 13 & 8 & 2 & 4 & 1 & 2 & 3 & 10 & -7 & $\mathbf{5 1}$ \\
\hline $\mathbf{1 0}$ & 15 & 13 & 8 & 2 & 4 & 1 & 2 & 3 & 10 & -7 & $\mathbf{5 1}$ \\
\hline $\mathbf{1 1}$ & 15 & 13 & 8 & 2 & 4 & 1 & 2 & 3 & 10 & -7 & $\mathbf{5 1}$ \\
\hline $\mathbf{1 2}$ & 15 & 13 & 8 & 2 & 4 & 1 & 2 & 3 & 7 & -7 & $\mathbf{4 8}$ \\
\hline $\mathbf{1 3}$ & 15 & 13 & 8 & 2 & 4 & 1 & 2 & 3 & 7 & -7 & $\mathbf{4 8}$ \\
\hline $\mathbf{1 4}$ & 15 & 17 & 8 & 2 & 4 & 1 & 2 & 3 & 7 & -7 & $\mathbf{5 2}$ \\
\hline $\mathbf{1 5}$ & 15 & 17 & 10 & 2 & 4 & 1 & 2 & 3 & 4 & -7 & $\mathbf{5 1}$ \\
\hline $\mathbf{1 6}$ & 15 & 17 & 8 & 2 & 4 & 1 & 2 & 3 & 4 & -7 & $\mathbf{4 9}$ \\
\hline $\mathbf{1 7}$ & 15 & 20 & 10 & 2 & 4 & 1 & 2 & 3 & 4 & -7 & $\mathbf{5 4}$ \\
\hline
\end{tabular}




\begin{tabular}{|c|c|c|c|c|c|c|c|c|c|c|c|}
\hline \multicolumn{12}{|c|}{ SR2 } \\
\hline 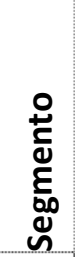 & 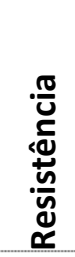 & ơ & 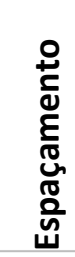 & 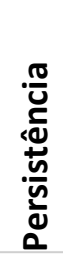 & $\begin{array}{l}\frac{\pi}{2} \\
\frac{1}{2} \\
\frac{0}{2}\end{array}$ & 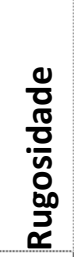 & 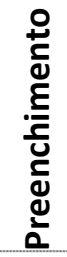 & 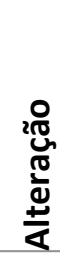 & 疍 & 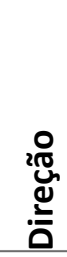 & $\sum_{\propto \mathcal{C}}^{\mathscr{\alpha}}$ \\
\hline 1 & 15 & 17 & 8 & 2 & 4 & 1 & 2 & 5 & 15 & -5 & 64 \\
\hline 2 & 15 & 20 & 10 & 2 & 4 & 1 & 2 & 5 & 15 & -5 & 69 \\
\hline 3 & 15 & 8 & 8 & 2 & 4 & 1 & 2 & 5 & 15 & -5 & 55 \\
\hline 4 & 15 & 20 & 10 & 2 & 4 & 1 & 2 & 5 & 15 & -5 & 69 \\
\hline 5 & 15 & 13 & 8 & 2 & 4 & 1 & 2 & 5 & 15 & -5 & 60 \\
\hline 6 & 15 & 20 & 10 & 2 & 5 & 1 & 2 & 5 & 15 & -5 & 70 \\
\hline 7 & 15 & 17 & 10 & 2 & 5 & 3 & 6 & 5 & 15 & -5 & 73 \\
\hline 8 & 15 & 17 & 8 & 2 & 5 & 3 & 6 & 5 & 15 & -5 & 71 \\
\hline 9 & 15 & 17 & 8 & 2 & 5 & 3 & 6 & 5 & 15 & -5 & 71 \\
\hline 10 & 15 & 20 & 8 & 2 & 5 & 3 & 6 & 5 & 15 & -5 & 74 \\
\hline 11 & 15 & 13 & 8 & 2 & 5 & 3 & 6 & 5 & 15 & -5 & 67 \\
\hline 12 & 15 & 20 & 15 & 2 & 5 & 3 & 6 & 5 & 15 & -5 & 81 \\
\hline 13 & 15 & 13 & 8 & 2 & 5 & 3 & 6 & 5 & 15 & -5 & 67 \\
\hline 14 & 15 & 20 & 20 & 2 & 5 & 3 & 6 & 5 & 15 & -5 & 86 \\
\hline 15 & 15 & 17 & 10 & 2 & 5 & 3 & 6 & 5 & 15 & -5 & 73 \\
\hline 16 & 15 & 20 & 10 & 2 & 5 & 3 & 6 & 5 & 15 & -5 & 76 \\
\hline 17 & 15 & 17 & 10 & 2 & 5 & 3 & 6 & 5 & 15 & -5 & 73 \\
\hline 18 & 15 & 17 & 8 & 2 & 5 & 3 & 6 & 5 & 15 & -5 & 71 \\
\hline 19 & 15 & 17 & 8 & 2 & 4 & 3 & 6 & 5 & 15 & -5 & 70 \\
\hline 20 & 15 & 17 & 8 & 2 & 4 & 1 & 2 & 0 & 15 & -5 & 59 \\
\hline 21 & 12 & 17 & 8 & 2 & 4 & 1 & 2 & 0 & 15 & -5 & 56 \\
\hline 22 & 12 & 13 & 8 & 2 & 4 & 1 & 2 & 0 & 15 & -5 & 52 \\
\hline 23 & 15 & 20 & 10 & 2 & 4 & 3 & 2 & 3 & 15 & -5 & 69 \\
\hline 24 & 15 & 13 & 10 & 2 & 4 & 3 & 2 & 3 & 15 & -5 & 62 \\
\hline 25 & 15 & 20 & 10 & 2 & 4 & 3 & 2 & 3 & 15 & -5 & 69 \\
\hline 26 & 15 & 13 & 8 & 2 & 4 & 3 & 2 & 3 & 15 & -5 & 60 \\
\hline 27 & 15 & 13 & 8 & 2 & 4 & 1 & 2 & 3 & 15 & -5 & 58 \\
\hline 28 & 15 & 13 & 8 & 2 & 4 & 1 & 2 & 3 & 15 & -5 & 58 \\
\hline 29 & 15 & 20 & 8 & 2 & 4 & 3 & 2 & 3 & 15 & -5 & 67 \\
\hline 30 & 15 & 17 & 8 & 2 & 4 & 3 & 2 & 3 & 15 & -5 & 64 \\
\hline 31 & 15 & 17 & 8 & 2 & 5 & 3 & 2 & 3 & 15 & -5 & 65 \\
\hline 32 & 15 & 20 & 10 & 2 & 5 & 3 & 2 & 3 & 15 & -5 & 70 \\
\hline 33 & 15 & 17 & 10 & 2 & 5 & 3 & 2 & 3 & 15 & -5 & 67 \\
\hline 34 & 15 & 17 & 8 & 2 & 5 & 3 & 2 & 3 & 15 & -5 & 65 \\
\hline 35 & 15 & 17 & 8 & 2 & 5 & 3 & 2 & 3 & 10 & -5 & 60 \\
\hline
\end{tabular}




\begin{tabular}{|c|c|c|c|c|c|c|c|c|c|c|c|}
\hline \multicolumn{12}{|c|}{ SR1 } \\
\hline 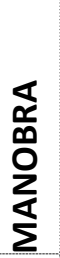 & 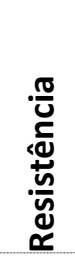 & $\underset{\sim}{\stackrel{0}{x}}$ & 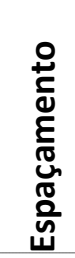 & 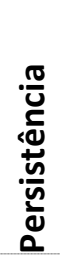 & $\begin{array}{l}\frac{0}{5} \\
\frac{t}{2} \\
\frac{0}{2} \\
\frac{0}{2}\end{array}$ & $\begin{array}{l}\frac{0}{0} \\
\frac{\pi}{0} \\
\frac{0}{0} \\
\stackrel{0}{0} \\
\vec{x}_{0}^{2}\end{array}$ & 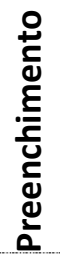 & 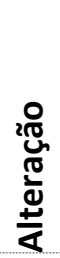 & 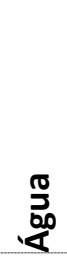 & 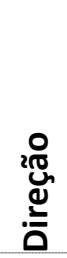 & $\sum_{\propto \sim}^{\mathscr{q}}$ \\
\hline 1 & - & - & - & - & - & - & - & - & - & - & 0 \\
\hline 2 & 15 & 8 & 8 & 2 & 4 & 3 & 6 & 5 & 15 & -7 & 59 \\
\hline 3 & 15 & 17 & 10 & 2 & 5 & 3 & 6 & 5 & 15 & -7 & 71 \\
\hline 4 & 15 & 20 & 15 & 2 & 5 & 3 & 6 & 5 & 10 & -7 & 74 \\
\hline 5 & 15 & 20 & 15 & 2 & 5 & 3 & 6 & 5 & 7 & -7 & 71 \\
\hline
\end{tabular}

\begin{tabular}{|c|c|c|c|c|c|c|c|c|c|c|c|}
\hline $\mathbf{1 0}$ & \multicolumn{10}{|c|}{ SR2 } \\
\hline $\mathbf{1}$ & 15 & 17 & 8 & 2 & 4 & 1 & 2 & 5 & 15 & -5 & $\mathbf{6 4}$ \\
\hline $\mathbf{2}$ & 15 & 17 & 8 & 2 & 4 & 1 & 2 & 5 & 15 & -5 & $\mathbf{6 4}$ \\
\hline $\mathbf{3}$ & 15 & 17 & 8 & 2 & 5 & 3 & 6 & 5 & 15 & -5 & $\mathbf{7 1}$ \\
\hline $\mathbf{4}$ & 15 & 17 & 8 & 2 & 5 & 3 & 6 & 5 & 15 & -5 & $\mathbf{7 1}$ \\
\hline $\mathbf{5}$ & 15 & 17 & 10 & 2 & 5 & 3 & 6 & 5 & 15 & -5 & $\mathbf{7 3}$ \\
\hline $\mathbf{6}$ & 15 & 20 & 10 & 2 & 5 & 3 & 6 & 5 & 15 & -5 & $\mathbf{7 6}$ \\
\hline $\mathbf{7}$ & 15 & 17 & 10 & 2 & 5 & 3 & 6 & 5 & 15 & -5 & $\mathbf{7 3}$ \\
\hline $\mathbf{8}$ & 15 & 13 & 8 & 2 & 4 & 1 & 2 & 0 & 15 & -5 & $\mathbf{5 5}$ \\
\hline $\mathbf{9}$ & 15 & 13 & 8 & 2 & 4 & 1 & 2 & 0 & 15 & -5 & $\mathbf{5 5}$ \\
\hline $\mathbf{1 0}$ & 15 & 17 & 8 & 2 & 4 & 3 & 2 & 3 & 15 & -5 & $\mathbf{6 4}$ \\
\hline $\mathbf{1 1}$ & 15 & 17 & 8 & 2 & 4 & 3 & 2 & 3 & 15 & -5 & $\mathbf{6 4}$ \\
\hline $\mathbf{1 2}$ & 15 & 17 & 10 & 2 & 5 & 3 & 2 & 3 & 15 & -5 & $\mathbf{6 7}$ \\
\hline $\mathbf{1 3}$ & 15 & 20 & 8 & 2 & 5 & 3 & 2 & 3 & 10 & -5 & $\mathbf{6 3}$ \\
\hline
\end{tabular}

\begin{tabular}{|c|c|c|c|c|c|c|c|c|c|c|c|}
\hline \multicolumn{10}{|c|}{ SR3 } \\
\hline $\mathbf{1}$ & - & - & - & - & - & - & - & - & - & - & 0 \\
\hline 2 & 15 & 17 & 8 & 2 & 5 & 5 & 6 & 5 & 15 & -5 & 73 \\
\hline 3 & 15 & 20 & 10 & 2 & 5 & 5 & 6 & 5 & 15 & -5 & $\mathbf{7 8}$ \\
\hline 4 & 15 & 20 & 10 & 2 & 5 & 5 & 6 & 5 & 15 & -5 & $\mathbf{7 8}$ \\
\hline $\mathbf{5}$ & 15 & 20 & 10 & 2 & 5 & 5 & 6 & 5 & 15 & -5 & $\mathbf{7 8}$ \\
\hline $\mathbf{6}$ & 15 & 20 & 10 & 2 & 5 & 5 & 6 & 5 & 15 & -5 & $\mathbf{7 8}$ \\
\hline
\end{tabular}

\begin{tabular}{|c|c|c|c|c|c|c|c|c|c|c|c|}
\hline \multicolumn{10}{|c|}{ SR4 } \\
\hline $\mathbf{1}$ & - & - & - & - & - & - & - & - & - & - & $\mathbf{0}$ \\
\hline $\mathbf{2}$ & 15 & 5 & 5 & 2 & 1 & 1 & 2 & 1 & 15 & -7 & $\mathbf{4 0}$ \\
\hline $\mathbf{3}$ & 15 & 8 & 8 & 2 & 4 & 1 & 2 & 1 & 15 & -7 & $\mathbf{4 9}$ \\
\hline $\mathbf{4}$ & 15 & 13 & 8 & 2 & 4 & 1 & 2 & 3 & 10 & -7 & $\mathbf{5 1}$ \\
\hline $\mathbf{5}$ & 15 & 13 & 8 & 2 & 4 & 1 & 2 & 3 & 7 & -7 & $\mathbf{4 8}$ \\
\hline $\mathbf{6}$ & 15 & 17 & 8 & 2 & 4 & 1 & 2 & 3 & 7 & -7 & $\mathbf{5 2}$ \\
\hline $\mathbf{7}$ & 15 & 17 & 8 & 2 & 4 & 1 & 2 & 3 & 4 & -7 & $\mathbf{4 9}$ \\
\hline $\mathbf{8}$ & 15 & 20 & 10 & 2 & 4 & 1 & 2 & 3 & 4 & -7 & $\mathbf{5 4}$ \\
\hline
\end{tabular}

